University of Louisville

ThinkIR: The University of Louisville's Institutional Repository

Electronic Theses and Dissertations

$5-2017$

\title{
Transversal approaches and ecological artwork.
}

Madison DeAnna Sevilla

University of Louisville

Follow this and additional works at: https://ir.library.louisville.edu/etd

Part of the Contemporary Art Commons

\section{Recommended Citation}

Sevilla, Madison DeAnna, "Transversal approaches and ecological artwork." (2017). Electronic Theses and Dissertations. Paper 2722.

https://doi.org/10.18297/etd/2722

This Master's Thesis is brought to you for free and open access by ThinkIR: The University of Louisville's Institutional Repository. It has been accepted for inclusion in Electronic Theses and Dissertations by an authorized administrator of ThinkIR: The University of Louisville's Institutional Repository. This title appears here courtesy of the author, who has retained all other copyrights. For more information, please contact thinkir@louisville.edu. 


\title{
TRANSVERSAL APPROACHES AND ECOLOGICAL ARTWORK
}

\author{
By \\ Madison DeAnna Sevilla \\ B.S. Appalachian State University, 2015
}

\begin{abstract}
A Thesis
Submitted to the Faculty of the

College of Arts and Sciences of the University of Louisville in Partial Fulfillment of the Requirements for the Degree of

Master of Arts in $\operatorname{Art}(\mathrm{c})$ and Art History Critical and Curatorial Studies
\end{abstract}

Hite Art Institute Department of Fine Arts University of Louisville Louisville, Kentucky

May 2017 

TRANSVERSAL APPROACHES AND ECOLOGICAL ARTWORK

\author{
By
}

Madison DeAnna Sevilla

B.S. Appalachian State University, 2015

A Thesis Approved on

April 17, 2017

by the following Thesis Committee:

\begin{tabular}{c}
\hline $\begin{array}{c}\text { Thesis Advisor } \\
\text { Chris Reitz }\end{array}$ \\
\hline Christopher Fulton \\
\hline Mehmed Kantardzic
\end{tabular}




\section{DEDICATION}

This thesis is dedicated to all four of my parents who have continually loved and supported me in every way imaginable. My kindness, patience, work ethic, and sense of humor are a direct result of your teachings. I would not be the woman that I am today without you.

I also want to thank my sisters and my love. You will never regain the time spent listening to my rants- $-\mathrm{I}$ am forever grateful. 


\section{ACKNOWLEDGEMENTS}

To Dr. Chris Reitz, Dr. Christopher Fulton, and Dr. Mehmed Kantardzic — thank you for your guidance and your immense patience during this process. I am grateful for your valuable feedback and direction. 


\title{
ABSTRACT \\ TRANSVERSAL APPROACHES AND ECOLOGICAL ARTWORK
}

\author{
Madison DeAnna Sevilla
}

April 17, 2017

This work explores systematic ecology as it relates to sculpture and language. This project exists in two parts: a written thesis and a thesis exhibition. Although both works explore ecological systems, Unseen: Visualizing Ecological Systems investigates visualizations and concepts of the ecological, whereas this thesis continues the exploration into the ramifications of disruptions in systems.

Ecological systems such as the environmental, social/mental, economic, and political define the foundations of our known world and encapsulate all regions of society. No single system can function independently of the rest and all systems contain some aspect of humansystem involvement. By using the work of environmental and conceptual artists, this thesis studies the limits of systems and examines artwork that seeks to reveal and conceal unrecognized human interaction. In the following chapters, I will examine the work of these artists through an ecological mindset as laid out by philosophers and theorists to showcase the varying degrees of ecological efficacy. 
TABLE OF CONTENTS

ACKNOWLEDGEMENTS $\quad$ PAGE

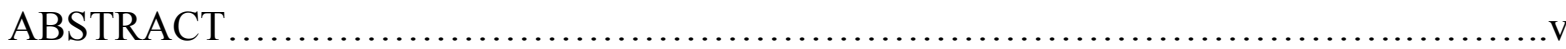

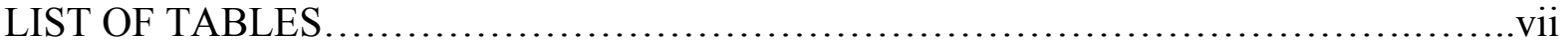

LIST OF FIGURES....................................................................

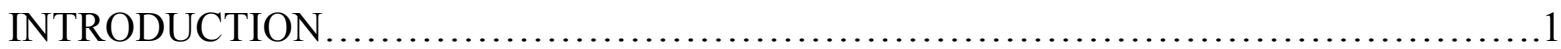

CHAPTER I: INTRODUCTION TO ECOLOGY AND TRANSVERSAL

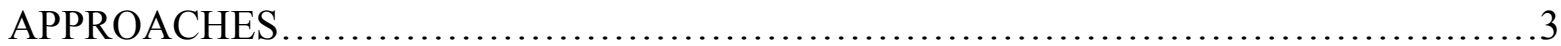

CHAPTER II: INEXTRICABILITY OF HUMAN INVOLVEMENT .......................18

Imaginary Landscapes............................................... 19

Closed Systems......................................................25

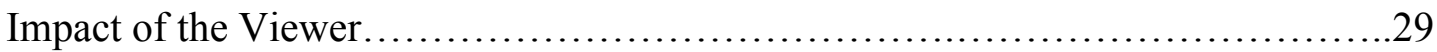

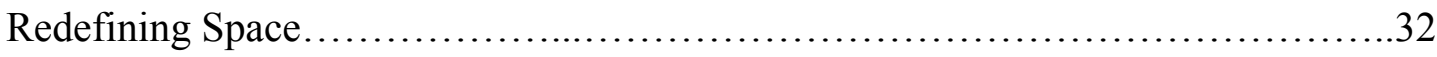

Questioning Value Systems.............................................. 34

Interdisciplinary Criticality.............................................. 37

CHAPTER III: THE REFERENCE OF RUBBLE ..................................... 39

CHAPTER IV: UNSEEN: VISUALIZING ECOLOGICAL SYSTEMS ........................53

CONCLUSION: SEPARATION BETWEEN REPRESENTATION AND FORM..........75

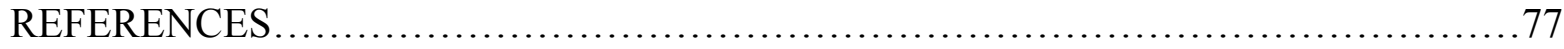

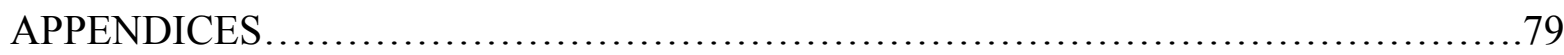

CURRICULUM VITA.......................................................... 89 


\section{LIST OF TABLES}

TABLE PAGE

1. Budget for Unseen: Visualizing Ecological Systems...............................79

2. Checklist for Unseen: Visualizing Ecological Systems.............................80 


\section{LIST OF FIGURES}

FIGURES

PAGE

1. Lieko Shiga. Rasen Kaigan (Spiral Shore) (2011)................................6

2. Hans Haacke. Condensation Cube (1965) .......................................... 10

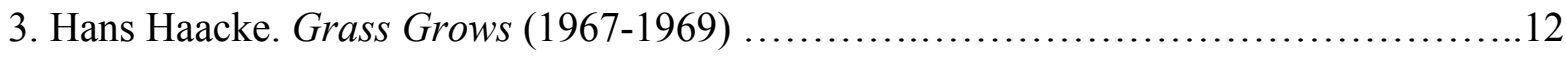

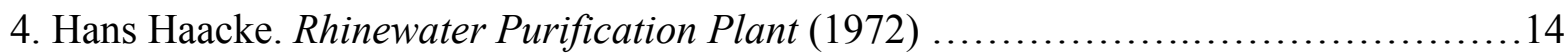

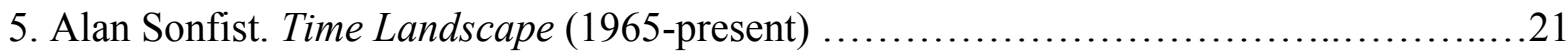

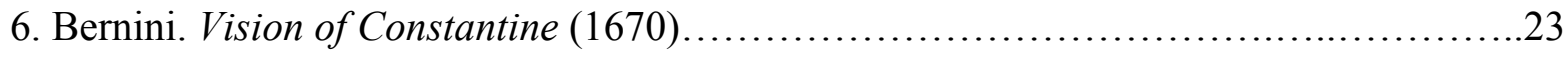

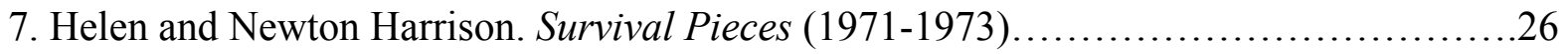

8. Helen and Newton Harrison. Survival Piece \#3: Portable Fish Farm (1971) ............28

9. John Lifton. Green Music (1976)............................................ 31

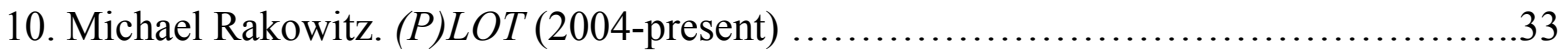

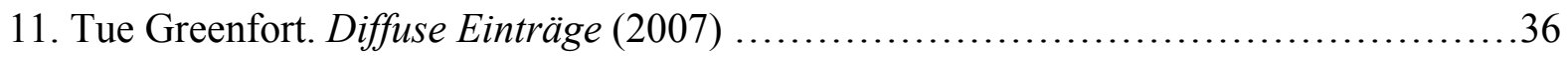

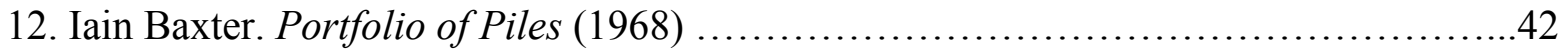

13. Robert Smithson. Rock Salt and Mirror Square I (1969) ..............................44

14. Robert Smithson. (Essen Soil and Mirrors) (1969) ....................................48

15. Robert Smithson. Nonsite (Franklin, New Jersey) (1968) ..........................51

16. Stephen Cartwright. Human Powered Outdoor Activity and Temperature 2014-2015

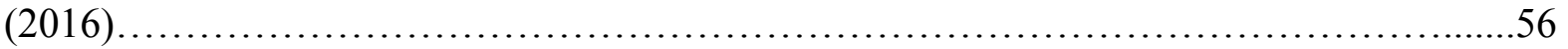

17. Stephen Cartwright. Human Powered Outdoor Activity 2014-2015 (2016) ..............58 


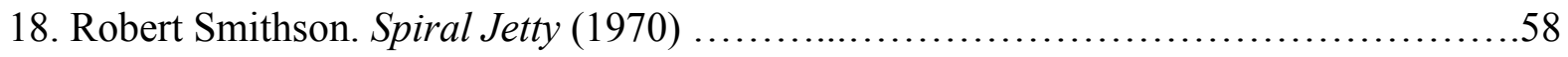

19. Stephen Cartwright. Chromatic Data Oscillator (2016) ...............................61

20. Stephen Cartwright. Bed Time Single Set Data 2012-2014 (2015) ......................63

21. Stephen Cartwright. Fort Peck (2008) ............................................63

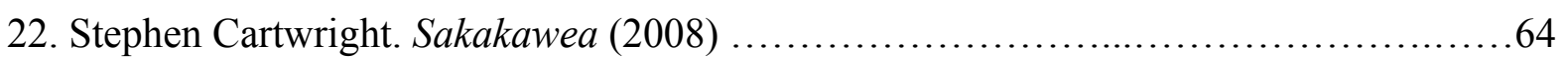

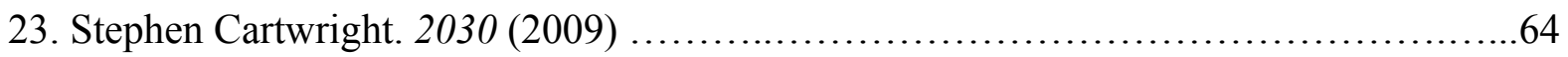

24. Shohei Katayama. E.G.O. (Everybody Grows Old) (2015) .............................68

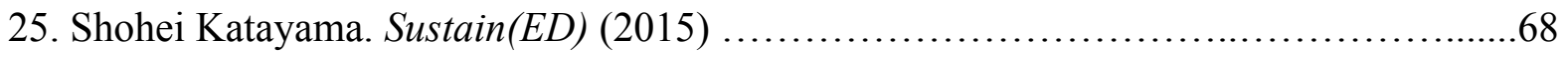

26. Shohei Katayama. Chained (2016) ............................................... 71

27. Shohei Katayama. Balance (2015) ............................................... 71

28. Shohei Katayama. Driving Me Nuts (2016) ........................................73

29. Floor plan for Unseen: Visualizing Ecological Systems.............................81

30. Floor plan for Unseen: Visualizing Ecological Systems............................. 81

31. Floor plan for Unseen: Visualizing Ecological Systems..............................8 82

32. Email blast: Unseen: Visualizing Ecological Systems..............................83

33. Email blast: Unseen: Visualizing Ecological Systems............................... 84

34. Press: Unseen Visualizing Ecological Systems

Triplett, Jo Anne, "Staff Pick: 'Unseen-Visualizing Ecological Systems.” LEO Weekly......85

35. Press: Unseen Visualizing Ecological Systems

Kramer, Elizabeth. "Ecology as seen through an artists' eyes." Courier-Journal. 5 Jan.

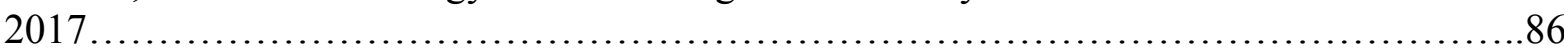

36. Press: Unseen Visualizing Ecological Systems

King, Nikki. "Hite Art Institute offers exhibition that examines art and ecology." UofL News.

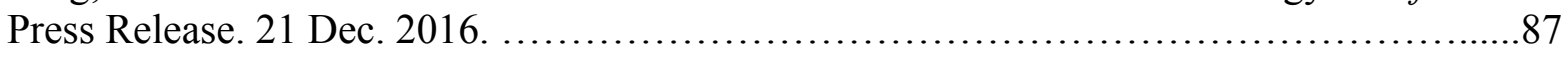

37. Press: Unseen Visualizing Ecological Systems

King, Nikki. "Hite Art Institute offers exhibition that examines art and ecology." UofL News.

Press Release. 21 Dec. 2016......................................................... 88 


\section{INTRODUCTION}

This thesis is written in conjunction with the exhibition Unseen: Visualizing Ecological Systems that took place at the Hite Art Institute Gallery at the University of Louisville between January $12^{\text {th }}$ to March $17^{\text {th }}, 2017$. This project, including both the thesis and exhibition, are conceived and executed as required by the University of Louisville to obtain a Master's Thesis in Critical and Curatorial Studies.

This project will look at the degree of separation between ecological systems in regards to man and representation as artists test the boundaries of material, language, time, perspective and place. The artworks in the following chapters attempt to either conceal or reveal man's position in ecology.

Chapter one examines Félix Guattari's The Three Ecologies as an introduction into ecology to establish a framework for the following chapters. The chapter will establish three ecologies in the text: the environmental, social, and mental. Using Hans Haacke's artworks as a case study, the chapter will showcase disruptions in systems that occur when the status quo is not upheld. This chapter will set the foundation for chapter two and the call for transversal art that Guattari bids at the end of The Three Ecologies.

Chapter two highlights the entanglements of human-system involvement and the inability to remove man from ecology in ecological artwork between the 1960s to present day. This chapter examines five artists and analyzes them according to their degree of ecological efficacy as established by Guattari and his demand for interdisciplinary approaches to art marking. By examining a range of environmental and conceptual works 
that attempt to resituate or secede man's impact on ecology, this chapter will establish a foundation for understanding the relationship between material and context.

Chapter three comments on Robert Smithson's artworks and the evolution of sculpture between the 1960s and 1970s as materials are removed from their original site and transformed from the visual to the verbal. This chapter examines a transversal approach to art that shifts material between ecologies and transforms the form and thus the signifier in the eyes of the viewer.

Finally, chapter four will discuss the artists in Unseen: Visualizing Ecological Systems and how they contribute to the dialogue and concepts analyzed in the former chapters.

This project looks at artwork that tests the boundaries of disruptions and examines the discourse that occurs when artwork uses interdisciplinary approaches. 


\section{CHAPTER I}

\section{INTRODUCTION TO ECOLOGY AND TRANSVERSAL APPROACHES}

Systems as described in the context of this chapter and those following it refer to the complex structures (social, economic, political, and otherwise) that maintain orderliness in the world. To uphold the status quo these systems must remain stable and productive. Note that being "productive" does not necessarily mean "positive" or "negative," but that individual components (living and otherwise) contribute towards the harmony of systems. In this case, society functions much like the colonies of insects that help maintain the status of natural landscapes around the world. Like colonies of bees, society has objectives that must be met in order to uphold the current political, economic, and social agenda. These systems are generally straightforward and appear in most of the everyday actions that people perform. A common example is of the laborer who completes a certain number of objectives to benefit his company who then supplies a consumer with a product or service. When disruptions, such as strikes, occur in these systems there can be massive repercussions that have an effect on the productivity and financial stability of not only the company, but also the consumers and other stakeholders. In environmental systems, honeybees gather nectar from flowers and pass it on to worker bees in their colony to build their honeycombs. This is a simplification of a more complex structure, but the basics boil down to creating and preserving the sanctity of the hive. Disruptions in this system can occur when the queen bee dies and the hive shifts its focus to reproducing a new queen. A colony of bees, much like a society of human beings, 
depends on the stability of systems. When an external or internal disruption threatens a system, the system must shift course and create new pathways to achieve a new harmony.

In order to understand ecology, one must first understand French philosopher Félix Guattari's ecosophy or ecological philosophy from his book The Three Ecologies. Ecosophy, a term coined by Guattari, focuses on the ecological harmony between human and nonhuman systems, whereas ecology acknowledges the existence of associations between organisms. In The Three Ecologies, Guattari breaks down these associations between organisms into separate ecologies: the environmental, mental, and social. ${ }^{1}$ He establishes that there are different types of ecological interactions between systems or structures. When systems are disrupted, the effects ripple outwards and affect not only one system, but all overlapping systems and the ecologies that encapsulate them. Guattari argues that there is an ecological crisis in the way that man currently approaches various systems and structures. Examples of these systems include political systems, cultural values, and the economy. A system does not exist as a closed circle and has no beginning or end. Systems have no timeline and no place, but are rather structures in society that function to uphold the current status quo. Guattari divides ecology into three categories to highlight the interactions that occur between systems. He argues the need to approach systems through an ecosophical approach that establishes a harmony between systems by acknowledging the intersections that occur and the different ecologies that are affected. While Guattari does not establish a strict criterion for the environmental, social, and mental ecologies, the focal point of the ecologies are on social relationships, human subjectivity, and environmental concerns. Guattari argues that human subjectivity threatens the other ecologies as man has a distinct focus on self-preservation versus the preservation of all.

${ }^{1}$ Guattari, Félix. The Three Ecologies. London: Continuum, Continuum impacts. 2008. Print. 
In order to avoid the grim future that Guattari lays out at the end of The Three Ecologies with man's destruction of the environment, he suggests that man must approach matters using interdisciplinary approaches. He establishes the need for human interaction in nonhuman systems and suggests that artists conceptualize transversal interactions more readily than politicians or scientists. Guattari stated in The Three Ecologies that:

Now more than ever, nature cannot be separated from culture; in order to comprehend the interactions between ecosystems, the mechanosphere and the social and individual Universes of reference we must learn to think "transversally."2

When there is a lack of transversal thinking, there is a passivity that develops in art exhibitions as viewers are content to separate their position from the subject of the work. For example, when an artist creates a photographic series about the harmful effects of Japan's 2011 Fukushima nuclear disaster, an event that was triggered by a 9.0 earthquake and created a tsunami that led to damage to the Daiichi power plant, the viewer can easily become an observer rather than an active part of the problem. In 2015 the Museum of Fine Arts Boston held the exhibition "In the Wake: Japanese Photographers Respond to 3/11." The exhibition was created to explore how photographers capture and digest traumatic events; however the majority of the photographers focused on the aesthetic beauty of the aftermath. Digital and chromogenic photographs by Lieko Shiga appeared on much of the marketing for the exhibition including the cover of the publication. ${ }^{3}$ Rasen Kaigan (Spiral Shore) (2011) (Figure 1) is aesthetically pleasing featuring lines and circles drawn in the sand. The image,

\footnotetext{
${ }^{2}$ Guattari. The Three Ecologies, pg. 29.

3 "In the Wake: Japanese Photographers Respond to 3/11." Henry Lois Foster Gallery. 2015. Retrieved November 2016. http://www.mfa.org/exhibitions/in-the-wake
} 
Figure 1: Lieko Shiga. Rasen Kaigan (Spiral Shore) (2011)

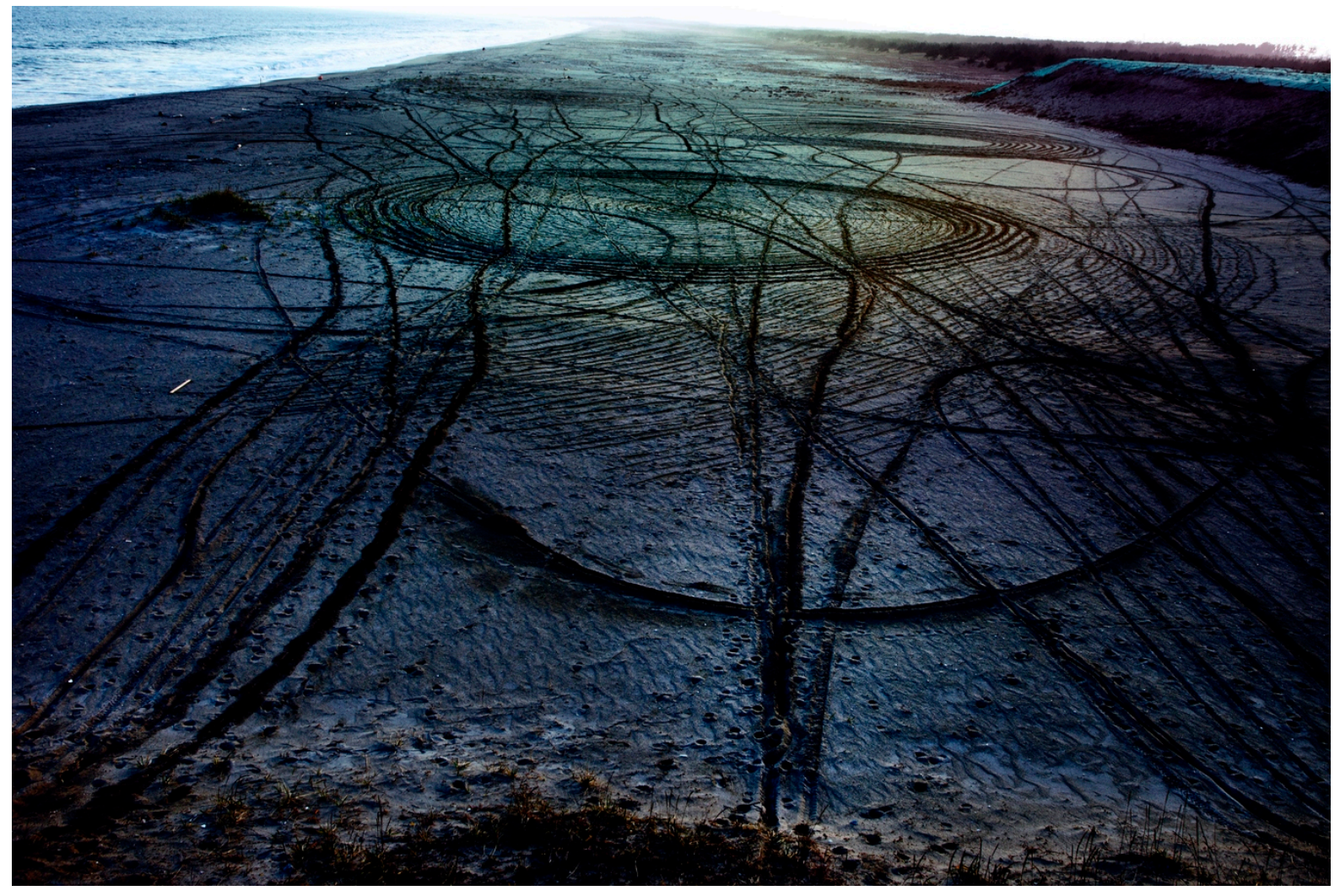


like much of his work is fantastical, detaching the image from the reality of the destruction and giving the viewer room to become a passive viewer. Shiga and many of the other artists in the exhibition approached the 2011 Fukushima nuclear disaster aesthetically rather than transversally. The artists separated the aftermath of the disaster from the societal issues leading up to it.

This type of work (while attractive) does not fall into an ecological framework. Ecological artwork transverses multiple paths revealing or concealing man's role in the three ecologies by testing the limits and boundaries of various systems. Art historian T.J. Demos examines such systemic intervention in his book Decolonizing Nature. Demos works off of Guattari's ecological philosophy to examine the relationships between visual culture, ecology, politics, and geography. He reviews the way that many artists have approached environmental art using the term "eco-aesthetics" to describe work that is concerned with the restoration of land to a pre-colonial state. ${ }^{4}$ Demos rejects work that attempts to separate nature from man's position in society because of its lack of interdependence. He continues, like Guattari, to mandate artists to create ecological work that extends past the eco-aesthetic and into an approach that acknowledges the interdependence of ecologies.

The overlapping regions between ecologies are present in how man organizes and exploits the environment. Scottish geographer Neil Smith coined the term "financialization of nature" to explain the tendency for the natural world to become a regulated commodity in the

\footnotetext{
${ }^{4}$ Demos, T.J. Decolonizing Nature: Contemporary Art and the Politics of Ecology. Sternberg Press, 2016. Print. p. 17.
} 
world market. ${ }^{5}$ The process of financializing nature is not a new concept, but is rather a relatively new term to describe how we monetarily value everything from oil to airspace. Often seen as a negative concept, the financialization of natural materials transforms resources into commodified elements. However, the financialization of nature is not always malicious, and instead can protect endangered species and limited resources. For example, ivory, which comes from elephant tusks, has a financial value placed on them, and as a result, elephants become a commodity. The government places their own value on the endangered species in terms of funding and resources spent protecting the animals and stopping poachers. Wildlife refuges also give endangered species a financial value through admissions and membership prices. In the 1980s and 1990s, biogenetic scientists began research in gene therapy turning cells and genes into a commodity. ${ }^{6}$ Large organizations utilize patents on specific genes and strands of agricultural materials in their production process. Bourbon distilleries, for example, use a specific strand of yeast during the fermentation process to make bourbon that is exclusive to that distiller. As the population increases, humans consume natural resources at a more rapid rate. This has led scientists to experiment with growing various materials in a laboratory setting in order to decrease the use of natural resources and the byproducts created in the process of harnessing them. These are only a handful of the systems that man takes part in and is the reason why Guattari advocates for artists to think

${ }^{5}$ Demos. Decolonizing Nature: Contemporary Art and the Politics of Ecology. p. 26. See, " Nature became prey to the financial markets' transformed into an object of venture capital speculation 'nature as an accumulation strategy,' as geographer Neil Smith called it, its value came to be dined economically based on the promise of profits as determined by derivatives in the stock market."

${ }^{6}$ Demos. Decolonizing Nature: Contemporary Art and the Politics of Ecology. p. 105. See, "No longer seen as finite, nature was conceptualized as technologically reproducible, which led to the biogenetic capitalism of the ' 80 s and ' 90 s, when individual genes, cells, proteins, and bodies were first commodified for pharmaceutical, medical, military, and agricultural applications, from gene therapy to biological weapons." 
transversally. Guattari is not suggesting that nature should be untainted by man and vice versa, but rather that it is impossible to separate man from ecology. Thus interdisciplinary thinking that reveals the intersections between systems is important to maintaining harmony in the three ecologies in order to prevent future environmental, social, or mental disasters.

In the 1960 s as more countries developed weapons of mass destruction and scientists decoded DNA and genetic sequencing, artists began experimenting with new materials. Conceptual and systems oriented artist Hans Haacke used his interest in unconventional materials to analyze systems and reveal the disruptions that can occur through human intervention. The conceptual art of the 1960s came from a desire to produce experiences through an art object. ${ }^{7}$ Following the pop-art movement and artists like Andy Warhol whose work critiqued commodity culture and mechanical reproduction, artists became less interested in the art making process and began to stray away from art objects "as the object becomes merely an end product." ${ }^{, 8}$ Haacke’s Condensation Cube (1965) (Figure 2) communicates the physical exchange between man and nature in an organic way requiring the viewer to experience the work. This sculpture features a clear Plexiglas container filled

\footnotetext{
${ }^{7}$ Lippard, Lucy R., and Chandler, John. “The Dematerialization of Art (1967-68)," Art International, February, 1968. Web. Retrieved 14 Mar. 2017. p. 1. See, “A highly conceptual art, like an extremely rejective art or an apparently random art, upsets detractors because there is 'not enough to look at,' or rather not enough of what they are accustomed to looking for. Monotonal or extremely simple-looking painting [...] exist in time as well as in space because of two aspects of the viewing experience. First, they demand more participation by the viewer, despite their apparent hostility [...] More time must be spent in experience of a detail-less work, for the viewer is used to focusing on details and absorbing an impression of the piece with the help of these details. Secondly, the time spent looking at an 'empty' work, or one with a minimum of action, seems infinitely longer than action-and detail- filled time." ${ }^{8}$ Lippard. "The Dematerialization of Art (1967-68)." p.1. See, "During the 1960's, the antiintellectual, emotional/intuitive processes of art-making characteristic of the last two decades have begun to give way to an ultra-conceptual art that emphasizes the thinking process almost exclusively. As more and more work is designed in the studio but executed elsewhere by professional craftsmen, as the object becomes merely the end product, a number of artists are losing interest in the physical evolution of the work of art."
} 
Figure 2: Hans Haacke: Condensation Cube (1965)

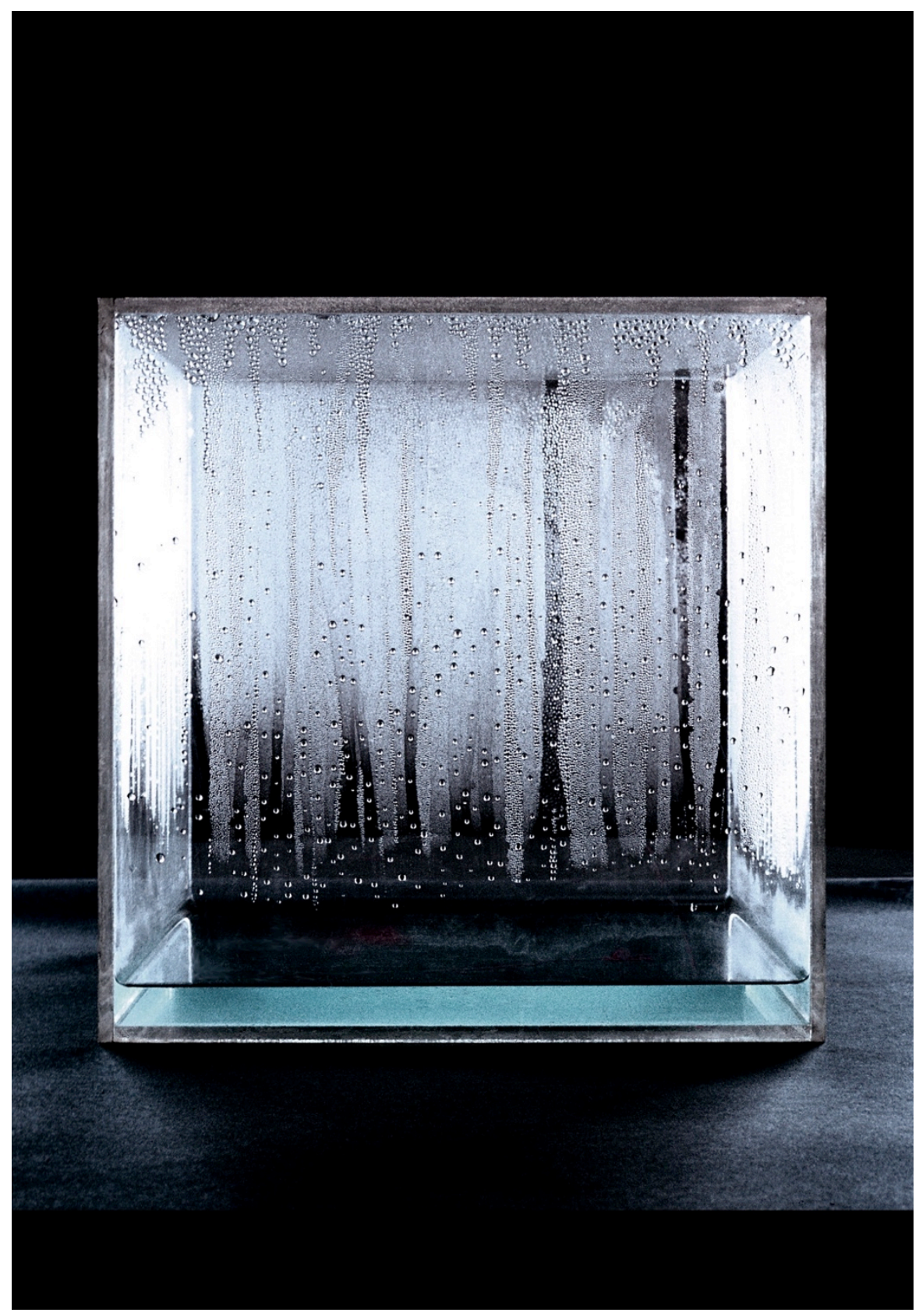


with a small amount of water and relies on the presence of viewers as a trigger. The container, which sits in the middle of the room, transforms as the temperature in the room rises or falls due to the number of bodies entering the exhibition space. As the viewer's body heat causes the room temperature to rise, the container becomes humid and condensation forms on the glass inside of it. In this way, Haacke incorporates the viewer into the work exposing that they themselves, through their mere existence, are a factor in the environmental sphere. The work activates and changes form because of the viewer's presence, but it also exists outside of their participation.

Haacke's artworks focus on various systems: atmospheric, political, hierarchical, and technological. Haacke describes the responsibility of the artist stating that it is of the artist's concern to make art in regards to the systems that he takes part in. ${ }^{9}$ Condensation Cube reveals the complexity of environmental ecology that is often unacknowledged, and it highlights the ease of human involvement in disrupting the status quo of the atmosphere in the gallery space. Condensation Cube acts as a representation of a larger environmental ecology and reveals the entanglements of ecologies. Here Haacke uses natural resources such as water to demonstrate how human involvement (in this case body heat) can have a seemingly minute impact on natural materials. The manner in which Haacke approaches ecology in his artwork forces the viewer to acknowledge their position in the ecosystem and the immense impact that man can have. In 1967, Haacke tested the boundaries of systems in his installation Grass Grows (1967-1969) (Figure 3), which brings natural

\footnotetext{
${ }^{9}$ Benthall, Jonathan. Science and Technology in Art Today. New York: Praeger,1972. Print. Praeger world of art series; Praeger world of art series. p. 129. See, "The artist's business requires his involvement in practically everything...it would be bypassing the issue to say that the artist's business is how to work with this and that material and manipulate the findings of perceptual psychology, and that the rest should be left to other professions...the total scope of information he receives in one day is of concern. ${ }^{9}$
} 
Figure 3: Hans Haacke. Grass Grows (1967-1969)

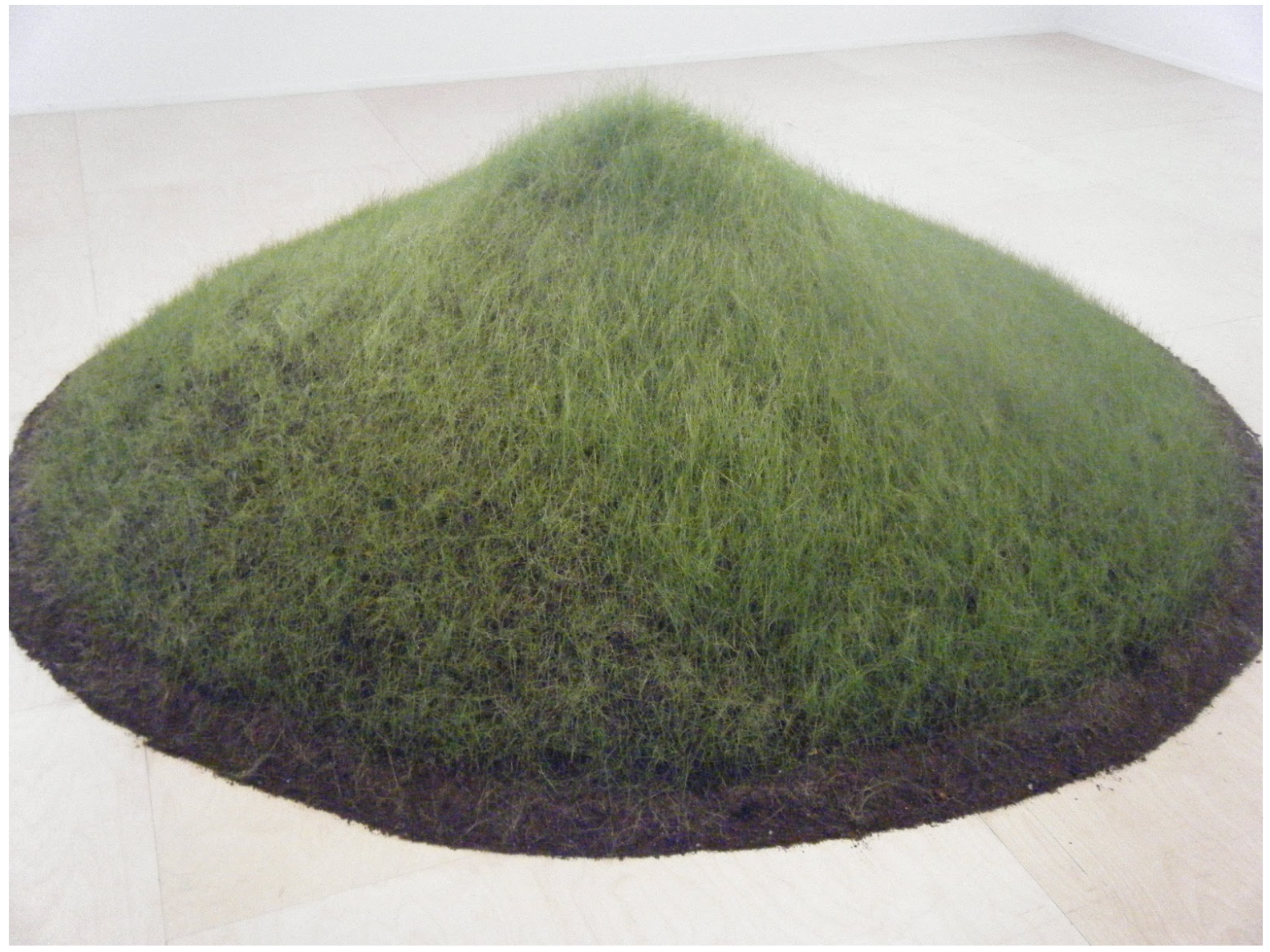


materials into the gallery space. The work consists of a mound of dirt with seeds that germinate over the course of the exhibition according to the conditions of the interior space. Installed in multiple exhibitions, Grass Grows reacts differently under a range of conditions that are neither established nor modified by the artist. Haacke places grass in the center of a room and allows it to grow or die throughout the course of the exhibition. Haacke's work, like other ecological artworks, questions the relationship between man and nature, art and ecology. He pushes limits through his use of natural materials and resituates core concepts in art, sculpture, and installation by showcasing a natural process, such as grass growing, as a work of art. A viewer cannot be passive when engaging with Grass Grows as the sculpture itself asks the viewers to question the works place in a gallery setting. Grass Grows is temporary. The sculpture actively exists in ecology; another installation cannot perfectly replicate the sculpture due to the use of living materials. The sculpture is neither static nor tangible and requires mental participation from the viewer. The life cycle of the grass becomes a sculpture that questions material culture by existing only in real time in the gallery space. The gallery then disposes of the grass after the close of the installation and seeds are replanted in new soil before the next exhibition resulting in an entirely new sculpture.

Following such political, social, and cultural events such as the Watergate scandal and the Vietnam War, in 1972 Haacke created the Rhinewater Purification Plant (Figure 4) indoor installation at the Museum Haus Lange in Krefeld, Germany, which critiqued discharge from the local sewage plant. The sculpture incorporates not only environmental and mental ecologies, but moves into the social realm as Haacke's works become more politically engaged. The installation both urged the Krefeld Sewage Plant to take responsibility for their pollution in the Rhine River and offered solutions for better filtering 
Figure 4: Hans Haacke. Rhinewater Purification Plant (1972)

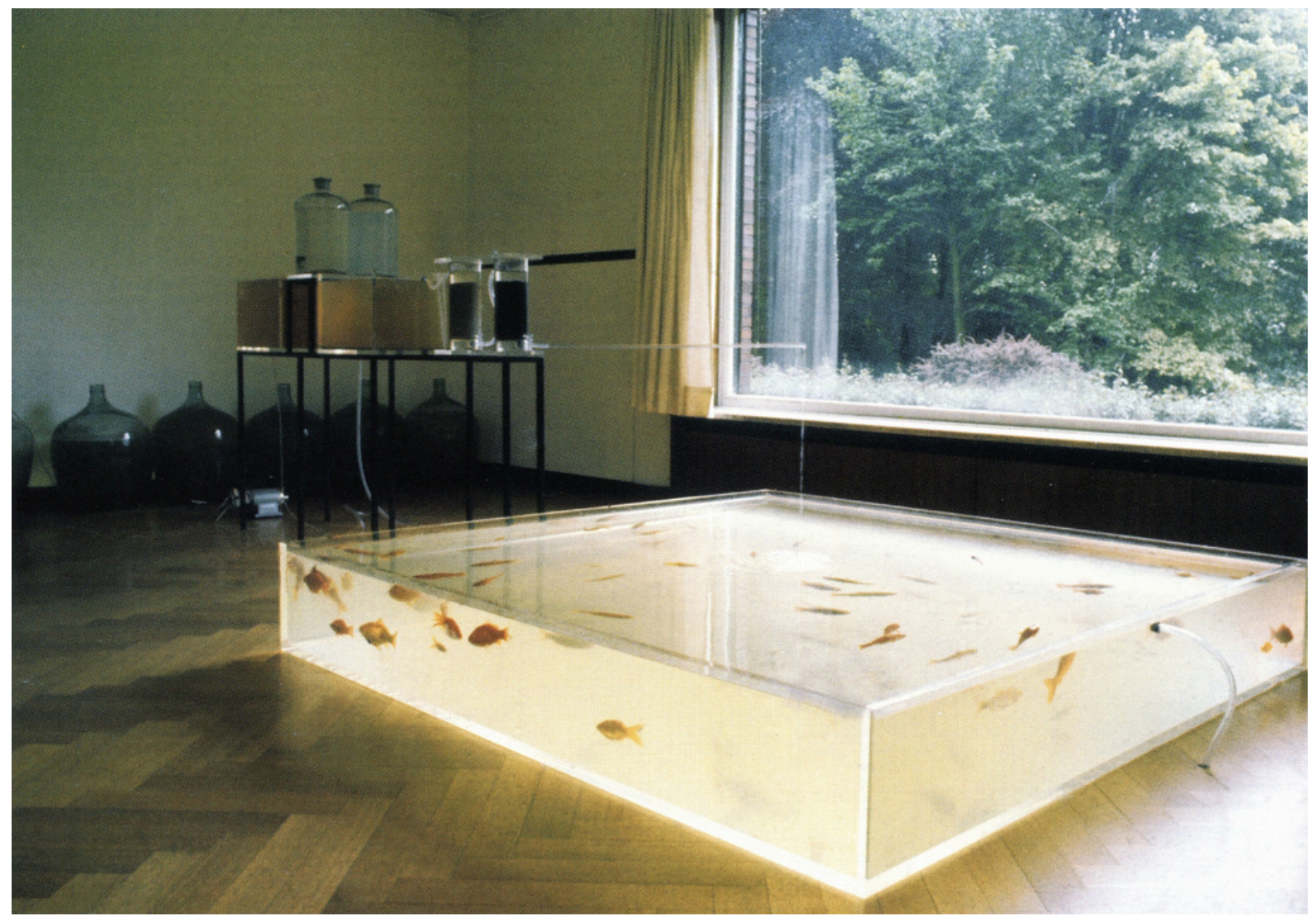


their water. Haacke set up a clear Plexiglas box filled with live fish and filtered water from the sewage plant. Over the course of the exhibition, Haacke used a gray-water system that cycled water through a filtration process that later filled the tank and watered museum grounds. The goldfish acted to confirm the purity of the filtered water and to display how pollution in the Rhine River could be easily decreased. Mental ecologies have started to shift as more programs involving environmental awareness and reductions in waste are being developed. California has enacted a law that bans the use of plastic bags and requires stores to charge customers ten cents for paper bags. The law was created in an attempt to reduce plastic waste and encourage people to either utilize recycled paper bags or bring their own reusable bag. ${ }^{10}$ While this is a small step towards larger environmental policies, the law forces individuals to confront their role in environmental ecology. Before major environmental changes can occur, as a society we need to alter how we approach the topic of sustainability and the role of man and his byproducts. Guattari hopes to achieve alternative approaches by attacking complex situations in a transversal manner.

Changes in environmental, social, and mental ecologies are heavily dependent on man's involvement due to how we have commodified and integrated society into all aspects of ecology. Disruptions in systems can occur naturally through the spread of diseases, the impact from natural disasters, or the creation of new species through evolutionary means. However, it has become impossible to separate man from these scenarios without naively disregarding the role that society and capitalistic tendencies play in environmental, political, and social systems. In the United States, an established budget decides how much money

\footnotetext{
${ }^{10}$ Gutierrez, Melody. "California becomes first state to ban plastic bags." San Francisco Chronicle. 30 Sept. 2014. Web. 11 Dec. 2016.

http://www.sfgate.com/politics/article/California-becomes-first-state-to-ban-plastic-bags5791041.php
} 
goes towards different sectors including scientific research and state of emergency funds. The recent Zika virus outbreak, a virus transmitted to people predominately through mosquito bites, is another example of disruptions within ecologies (in this case the environmental, mental, and social). In September of 2016, the United States Congress blocked funding meant to aid in research for the Zika virus even after cases were found locally in the U.S. The Senate Democrats orchestrated a block on the $\$ 1.1$ billion bill after Republicans pursued defunding Planned Parenthood. ${ }^{11}$ The instability of the political system affected scientific research on the Zika virus, a virus that had the potential to become a global disaster. The Zika virus and the political turmoil that occurred following the outbreak, emphasizes the power of intersecting ecologies and the ease in which potential disasters disrupt harmony. Guattari's ecology describes scenarios in which systems upset the current stability of the three ecologies. However, through transversal thinking and an acknowledgement that ecologies are interdependent, artists can break barriers by delving into interdisciplinary realms.

In this chapter, Haacke acts as a case study for transversal thinking. He begins using the viewer's experience to create interactions between art and the environment, art and philosophy, and art and politics. Artists like Haacke who reveal man's disruptions in various systematic frameworks confront the viewer with complex and potentially uncomfortable truths. In the next chapter, I will explore how ecological artists create work that transverses multiple disciplines and acknowledges the existence of the three ecologies and the interdependence of systems. The acknowledgment of interdependent systems allows artists to investigate a range of interactions between art, language, literature, philosophy, and politics.

\footnotetext{
11 “Zika outbreak: US Congress blocks Zika funding bill.” BBC News. 7 Sept. 2016. Web. 11 Dec. 2016. http://www.bbc.com/news/world-us-canada-37293329
} 
The work in the upcoming chapters have degrees of ecological efficacy with some traversing multiple systems whereas other focus more on the eco-esthetics of restoring nature to a precolonial landscape. 


\section{CHAPTER II}

\section{INEXTRICABILITY OF HUMAN INVOLVEMENT}

While the idea of a system often brings about images of closed circles and hierarchical diagrams, systems are not self-contained or free from intervention. In Guattari's three ecologies, there are overlapping systems that do not exist solely in a single ecology, but due to their complicated relationships can expand into all three. Pollution, for example, leads to significant impacts in environmental, social, and mental ecologies. Humans create substantial pollution that not only influences the environment through climate change and the destruction of habitats, but also impacts funding and regulations on both citizens and organizations. In the mid-1900s man became more environmentally aware after various disasters caused by anthropogenic pollution began to have an impact in regions such as North America and Europe. One such event occurred during the winter of 1952 with the Great Smog in London when pollution from coal utilized heavily in the cold months settled in the atmosphere due to an anticyclone. The event left thick smog that lingered in London from December fifth to December ninth. There were 4,500 estimated deaths directly after the event with tolls rising to an estimated 12,000 in years to follow due to the long-term effects of the pollution on the human respiratory system. ${ }^{12}$ Four years later, the Clean Air Act of July 1956 was passed in order to prevent such events from reoccurring and to acknowledge the impact

${ }^{12}$ Bell, Michelle L. et al. "A Retrospective Assessment of Mortality from the London Smog Episode of 1952: The Role of Influenza and Pollution." Environmental Health Perspectives, vol. 112, no. 1, 2004, p. 6-8. www.jstor.org/stable/3435787. 
that airborne pollution such as coal can have on not only the environment, but on the human condition. ${ }^{13}$ This one scenario shows the very real impact that climate and politics can have on ecologies when disruptions occur to the status quo. In this case, the disruptions that occurred were both positive and negative. Before the Great Smog, the British parliament ignored warnings against the use of coal during the winter months. When the anticyclone, a natural occurrence in weather systems, hovered over London the pollution from the smog killed thousands of citizens. As a result of this disaster, parliament developed clean air policies in the political system in order to prevent similar situations from reoccurring. Overlapping regions in ecologies occur on a daily basis, such as weather influencing travel conditions. As determined in chapter one, Guattari calls for artists to think transversally in order to emphasize the unrealized human-system involvement in ecology and to expand the perception of intersecting ecologies. This chapter examines the different degrees of ecological efficacy in the ecological artwork created between the 1960's to present day by investigating the transversal approaches used by artists.

\section{Imaginary Landscapes}

Early modernist sculpture brought about by artists like Rodin primarily fixated on the self-referential with the absorption of the base and a loss of place. ${ }^{14}$ In the 1950 s modern sculpture evolved by removing pedestals and integrating work into the physical space. Sculpture of the 1960s further lost its representation, moved away from the monumental, and

${ }^{13}$ Black J. "Intussusception and the Great Smog of London, December 1952." Archives of Disease in Childhood 88.12 (2003): 1040-2. Print.

${ }^{14}$ Krauss, Rosalind. "Sculpture in the Expanded Field." October, Vol 8. MIT Press. (Spring 1979), p. 34. See, "It is these two characteristics of modernist sculpture that declare its status, and therefore its meaning and function, as essentially nomadic. Through its fetishization of the base, the sculpture reaches downward to absorb the pedestal into itself and away from actual place; and through the representation of its own materials or the process of its construction, the sculpture depicts its own autonomy." 
began to focus on what was removed rather than what was there. Sculpture became about negativity and was easy to detect, but difficult to define. ${ }^{15}$ Sculptures were located based on their failure to assimilate into the landscape; however once identified as an artwork they were difficult to place. The architecture and landscape defined the sculpture through what it was not. ${ }^{16}$ Environmental artist Alan Sonfist's Time Landscape (1965-present) (Figure 5) bridges the gap between landscape and sculpture. Time Landscape develops from early modernist sculpture's fascination with the monumental. Sonfist attempts to elevate nature to the monumental by redefining place and representation.

At the corner of La Guardia Place and West Houston Street in Lower Manhattan exists a piece of land art created by Sonfist. Time Landscape, often dubbed an "ancient forest," attempts to recreate pre-colonial terrain by planting flora that existed before the $17^{\text {th }}$ century. Originally planted in three stages to highlight the different phases of plant development, the garden has now grown into an intermingling mass of trees, grass, flowers, and bushes. Began in the 1960s before the earth art movement, Sonfist's work takes on Demos' definition of eco-aesthetics by attempting to recreate a pre-colonial world devoid of human interaction. ${ }^{17}$ Some of the native trees include beech, elm, oak, and cedar, all of which exist today around the world. Sonfist's goal was not to prove that these plants could survive in present-day society, in fact he was sure that they would, but rather "To elevate

\footnotetext{
${ }^{15}$ Krauss. "Sculpture in the Expanded Field." p.34. See, "It began, that is, to be experienced more and more as pure negativity. At this point modernist sculpture appeared as a kind of black hole in the space of consciousness, something whose positive content was increasingly difficult to define, something that was possible to locate only in terms of what it was not." ${ }^{16}$ Krauss. "Sculpture in the Expanded Field." p.36. See, "it would probably be more accurate to say of the work that one found in the early sixties that sculpture had entered a categorical no-man's-land: it was what was on or in front of a building that was not the building, or what was in the landscape that was not the landscape."

${ }^{17}$ Demos. Decolonizing Nature: Contemporary Art and the Politics of Ecology. p. 38.
} 
Figure 5: Alan Sonfist. Time Landscape (1965-present)

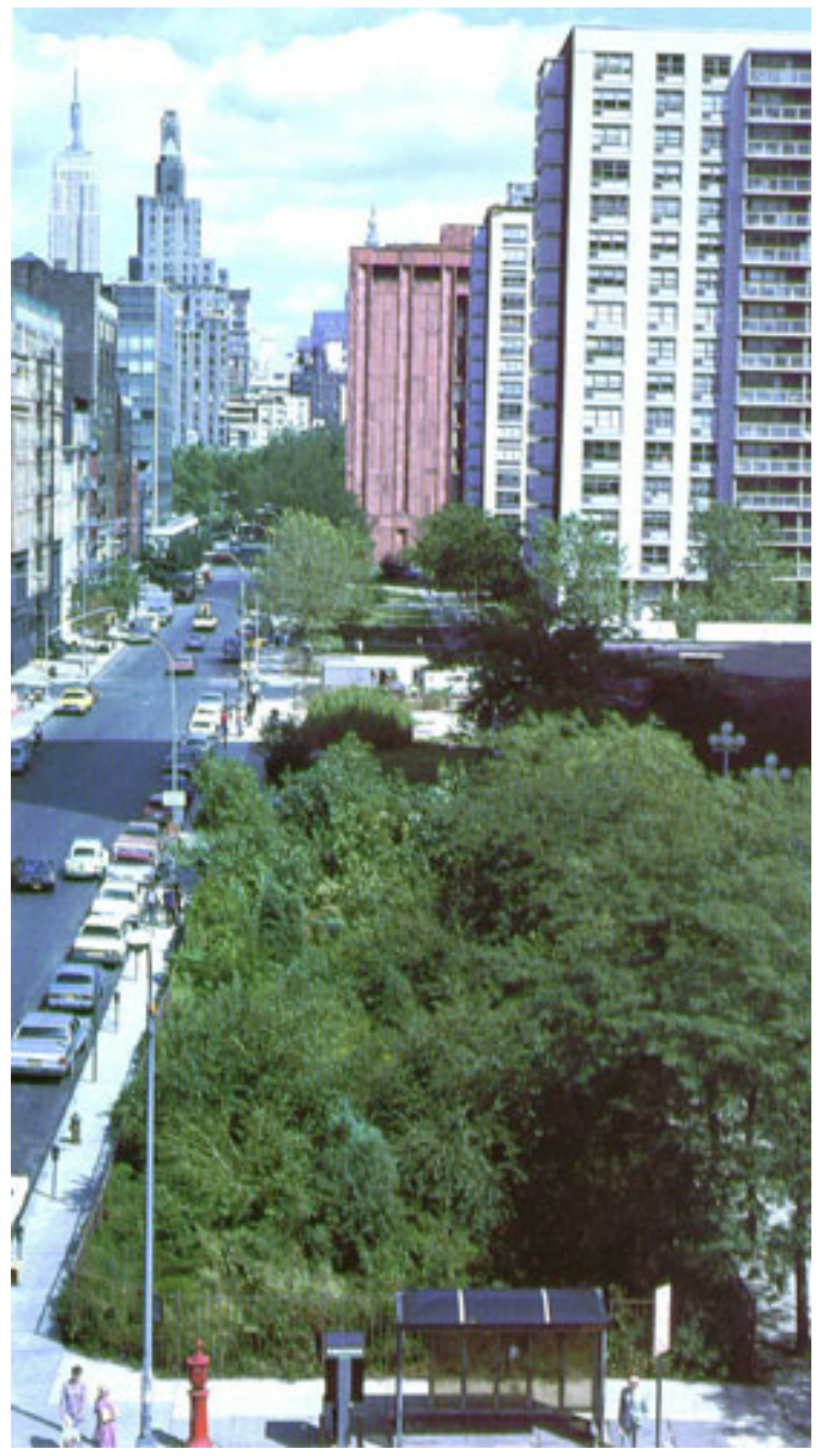


disappearing native landscapes to the status of historical monuments and, by extension, to sensitize people so they can view nature as an important part of their cultural heritage." 18 Time Landscape becomes a monument by acting as a representation of specific time that holds a symbolic meaning of innocence and purity untouched by man. Art Historian Rosalind Krauss describes the monumental as a "commemorative representation" that began with historic sculptures of artists like Bernini. ${ }^{19}$ Bernini's Vision of Constantine (1670) (Figure 6) in the Vatican is highly symbolic and functions as a representation of faith and the freeing of Christians from Roman persecution. In the sculptures of Bernini, the pedestal is essential in dividing place from representation. Separation between artwork and location continued for centuries leading up to modernist sculpture in the late 1800's. Time Landscape removes the pedestal, but continues to separate artwork from place and artwork from viewer by fencing off the miniature forest from the city. The sculpture is separated both contextually and physically from man as if to preserve it from the touch of human involvement. The work tells a narrative about the region in the pre-colonial era while continuing to grow in a modern day society. In this way, Sonfist connects past to present to create a sculpture that is timeless spanning centuries of history.

While this work acknowledges environmental ecologies, it does not restore nature to a time not yet marked by man as described by Sonfist. Nor does Time Landscape investigate transversal solutions that could exist at a global level today. Guattari calls for transversal artwork that spans the three ecologies in a forward thinking manner. Both Guattari and Demos maintain that in order for work to be truly transversal, it must not separate nature from today's culture. As can be seen through climate change and other environmental

${ }^{18}$ Demos. Decolonizing Nature: Contemporary Art and the Politics of Ecology. p. 40.

${ }^{19}$ Krauss. "Sculpture in the Expanded Field," p. 33. 
Figure 6: Bernini. Vision of Constantine (1670)

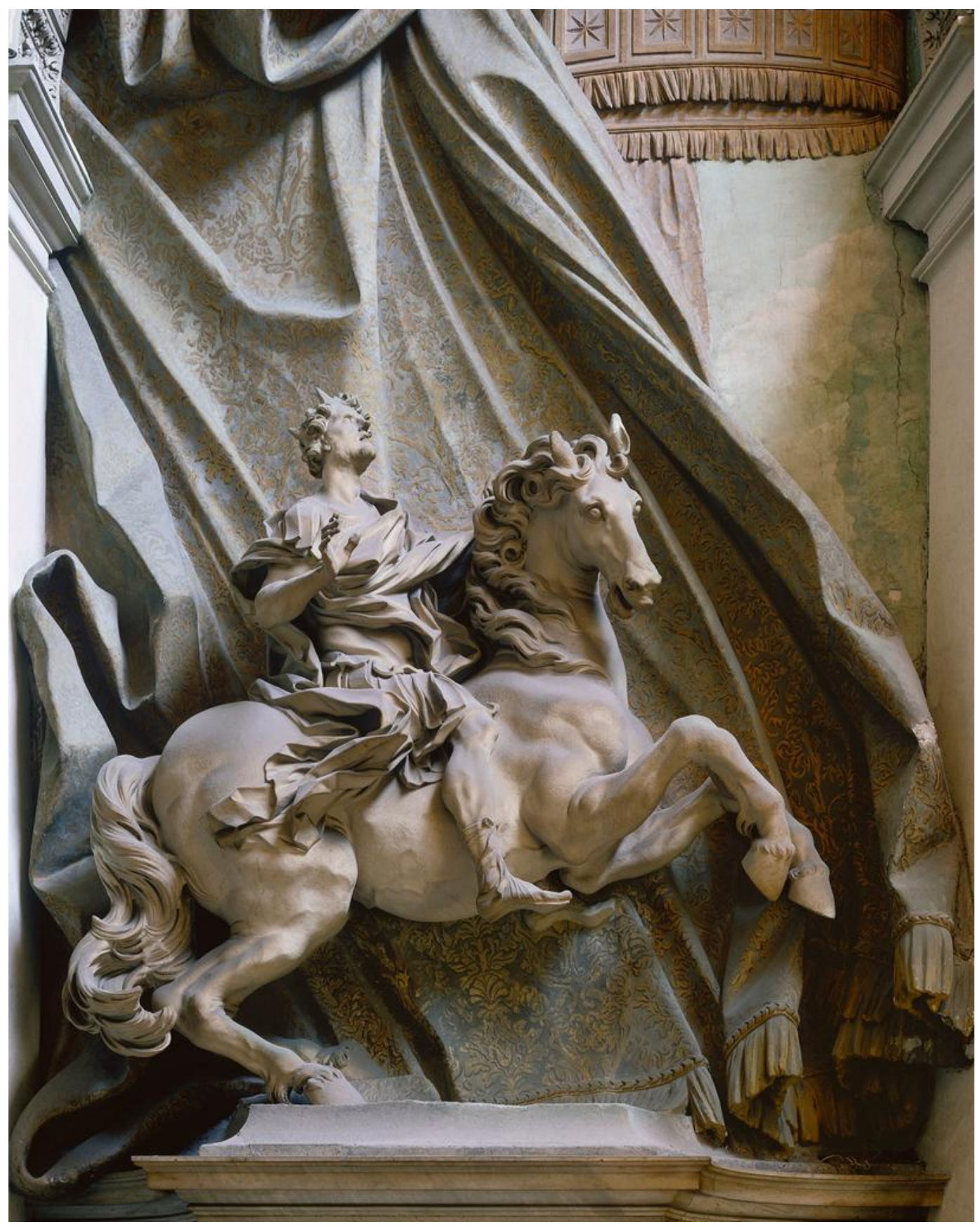


impacts, man has greatly affected the current global landscape not only through population growth, architectural development, and deforestation, but also through pollution, food waste, and the overconsumption of natural resources. Often artists focus on the environmental aspect of ecology, aware of the changes occurring, but unsure of the complexity that exists between individual regions. Although fenced off from visitors, Time Landscape remains consistently integrated into city life. Local pollution, city ordnances, and cross-pollination from local species of wildlife and insects continue to influence the sculpture. Sonfist did not create a strictly pre-colonial ecosystem, but rather displayed species that existed at that time to give a false sense of place and heritage. In The Three Ecologies, Guattari utilizes the experiment conducted by French biologist Alan Bombard to explain the impossibility of reconstructing "former ways of living. ${ }^{, 20}$ Guattari states that while on the one hand we must "make do with [the present] situation, on the other we must acknowledge that it requires a reconstruction of the objectives and the methods of the whole of the social movement under today's conditions.. ${ }^{21}$ In the experiment, Bombard supplied a live, seemingly healthy octopus that had been living in polluted waters into a container of clean unpolluted seawater. One would assume that unpolluted water would benefit the creature, but instead the octopus promptly sank in the container and died from the shock of the clean water. When artists create works that offer fantastical representations of the present-day ecosystem, they are attempting to place man back into a world free of pollution and conceal the human-system involvement that occurs in the everyday. In Sonfist's work, he does not acknowledge the responsibility of man and constructs a past void of human involvement. Sonfist's Time Landscape acts as a souvenir of the past and only exists because man replanted seeds in a

${ }^{20}$ Guattari. The Three Ecologies. p. 28.

${ }^{21}$ Guattari. The Three Ecologies. p. 29. 
small stretch of Manhattan. Sonfist's Time Landscape acts as a representation of another time and a temporary visual revitalization of nature, but it does not authentically encapsulate the conditions of a pre-colonial era.

\section{Closed Systems}

Following the Moon landing of Apollo 11 in 1969 and the first ever Earth Day celebration in 1970, environmental protections and ecological awareness was becoming more prominent. In 1971, the non-governmental environmental activist group Greenpeace was founded and has since continued to advocate for various environmental protections around the globe. President Nixon also founded the Environmental Protection Agency (EPA) in the late 1970s. Following the formation of the EPA a range of environmental acts were passed in the 1970s including the Noise Control Acts, Clean Water Act, Endangered Species Act, and Safe Drinking Water Act. Each of these laws placed restrictions on human-system involvement in order to decrease anthropogenic disruptions in the ecologies. Misinterpretations of ecology and the attempts to completely remove human impact from various systems has prompted Demos to advocate for art that investigates the themes of ecology and sustainability. In his article "The Politics of Sustainability: Contemporary Art and Ecology," Demos examines the issues with sustainable and ecological art stating that many environmental artists place man in a closed systems separate from the other ecologies. In the 1970s, Helen and Newton Harrison explored "the issue of survival" as a theme to investigate sustainable practices that escape the need for a middleman in all essential activities. ${ }^{22}$ In their Survival Pieces (1971-1973) (Figure 7), they focus on the survival of

\footnotetext{
${ }^{22}$ Bijvoet, Marga. Art As Inquiry: Toward New Collaborations between Art, Science, and Technology. New York: Peter Lang, 1997. Print. American University Studies. Series XX, Fine arts, v. 32. p. 137.
} 
Figure 7: Helen and Newton Harrison. Survival Pieces (1971-1973) specifically their

\section{Portable Orchard}

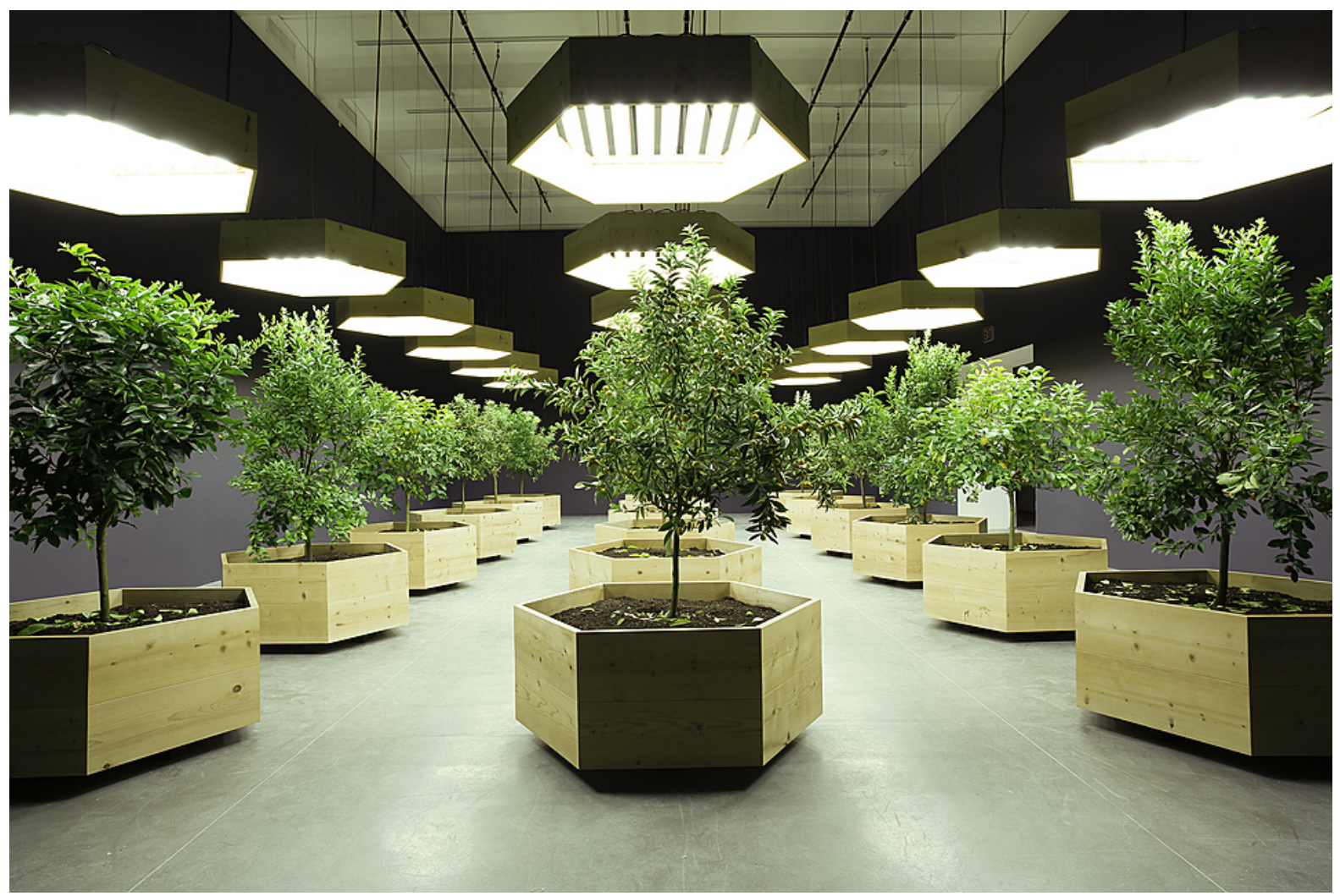


man rather than the survival of the entire ecosystem. The Harrison's often refer to their work in ways that do not acknowledge the existence of multiple ecologies. Newton Harrison stated that in order to ponder what Earth means to man, he "decided to make earth" by gathering "different kinds of manure, sewage, sawdust, vegetable matter, clay and sand." ${ }^{23}$ The Harrisons approached this project in an attempt to create an anthropocentric closed system. They not only believed that man could create Earth, but assumed that a self-sustaining system would not impact other ecologies. The goal of the Survival Pieces was to make selfcontaining ecosystems; however, as art historians have reviewed, the works often involved energy or governance from outside sources. Survival Piece \#3: Portable Fish Farm (Figure 8) was exhibited in London at the Hayward Gallery in 1971 as an example of sustainability. In the work, the Harrison's goal was to remove the middleman from every aspect of food preparation in order to serve a feast to a gallery full of attendees. The performance piece consisted of eight rubber lined tanks each containing catfish, brine shrimp, and lobsters. The fish were harvested at a farm with help from the artists and then brought to the gallery to complete the performance, which consisted of killing, skinning, filleting, and frying the fish.

Where multiple critics like Jonathan Benthall criticized the work for disregarding the use of electricity that was supplied by large power stations and not self-generated, the true naiveté of the work comes from its lack of acknowledgement of outside systems. ${ }^{24}$ While harvesting, preparing, and cooking food is self-sustaining for the individual it is far from a novel idea and is not sustainable at a large scale in present-day society. Hunters and fishermen around the world have killed and prepared their own food for centuries. Due to population growth, fish and cattle farms have been created to keep up with demand.

${ }^{23}$ Bijvoet, Marga. Art As Inquiry: Toward New Collaborations between Art, Science, and Technology. p. 137.

${ }^{24}$ Benthall, Science and Technology in Art Today. p. 47. 
Figure 8: Helen and Newton Harrison. Survival Piece \#3: Portable Fish Farm (1971)

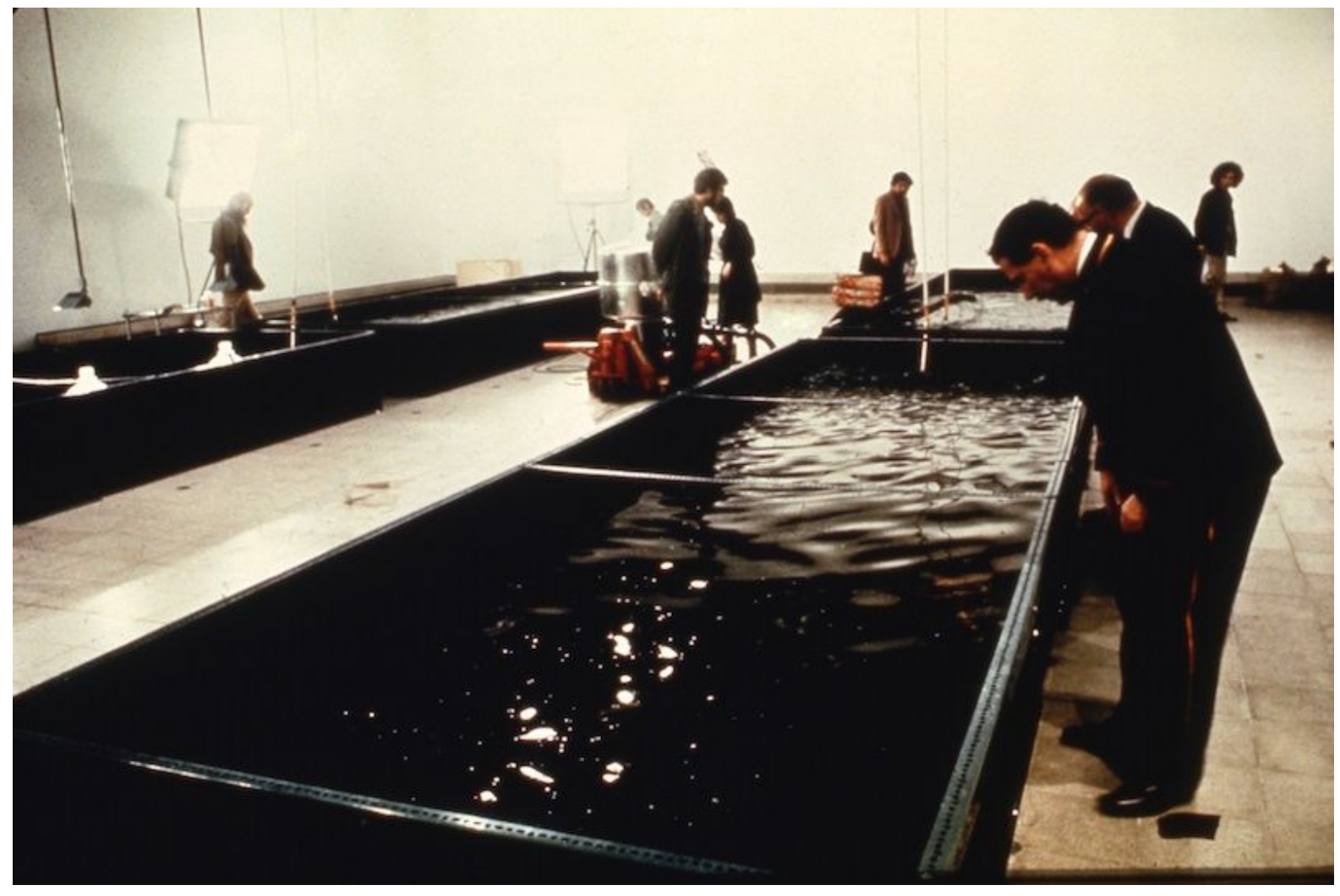


Removing the middleman from the equation may be sustainable at a small level, but it disregards other systems. Due to the demands of present-day life, it is impossible to replicate this form of sustainability at a global level. The majority of people do not have the money, facilities, or time to harvest their own food. Removing the middleman from the equation would also remove a large number of jobs around the world. There are also strict regulations surrounding fish farms in order to ensure that the fish are healthy and living in humane conditions. None of this was discussed or considered in the Survival Pieces created by the Harrisons.

\section{Impact of the Viewer}

The environmental art from the Harrison's developed through the conceptual art movement which focused on interventionist artwork and the dematerialization or deemphasis of material objects. Conceptual art in the 1970's became more political and actionoriented as de-commodification of artworks became popular among artists in response to the continuation of the Vietnam War. The war persisted resulting in more violence and higher costs in a fight against communism. After the war, Vietnam suffered from debilitating poverty due to US embargos that cut-off trade. The political climate during and after the war was fuel by conflict resulting in more interventionist artwork and prevalent activism. Artists in the environmental art movement became more action and performance oriented during the 1970's such as British architect and artist John Lifton. Lifton uses technology to reveal the relationship between man and nature. In the early 1970's, Lifton was developing a system called Interface 4, created to analyze human emotions and their effects on plants through a continuous and contingent structure. A glass dome with controlled settings (light, humidity, and temperature) encases the observed plant. Monitors placed on the plants sense their 
current condition (what Lifton calls the plant's mood) and transcribe their electro-magnetic response into a specific sound. ${ }^{25}$ The generated sound plays inside the globe for viewers. The globe alters the controlled settings based on the emotional response from the viewer. Each emotional response is transcribed from data into a physical change in the light, humidity, and temperature in the globe. As the settings change, the plant's condition follows suit creating a feedback loop in which modifications to the sound elicits a different emotional response from the viewer and thus repeats the cycle. The intricate binary system in Interface 4 shows the interconnectivity of systems and the effect that mental ecologies can have on the environment. This system was utilized later in Lifton's Green Music (1976) (Figure 9), a part of his series "The Secret Life of Plants," and exhibited in San Francisco at the Plant Conservatory in Golden Gate Park. The project underwent scrutiny concerning whether Lifton was truly creating a new form of interconnectivity between man and nature. While it is unclear the impact that human emotion can have on plant life, Green Music fostered conversations regarding the unrealized human-system involvement that may exist in the ecosystem. Although Green Music underwent criticism for creating a potentially fictional environment, Lifton questioned the dependent relationship between nature and human emotion that was later researched and confirmed by multiple sources. While it is uncertain the impact that mood has on plants, there are countless experiments conducted by scientists and psychologists regarding the impact that plants can have on human emotion, productivity, and creativity. ${ }^{26}$ Green Music is transversal and approaches human-system involvement through the mental, social, and environmental ecologies. The work is ecological through its awareness and transversal approach to various sphere of existence. Unlike the work of

${ }^{25}$ Benthall, Science and Technology in Art Today. p. 75.

${ }^{26}$ Shibata, Seiji, Naoto Suzuki. "Effects of an Indoor Plant on Creative Task Performance and Mood." Scandinavian Journal of Psychology 45.5. 2004. p. 373-381. Print. 
Figure 9: John Lifton. Green Music (1976)

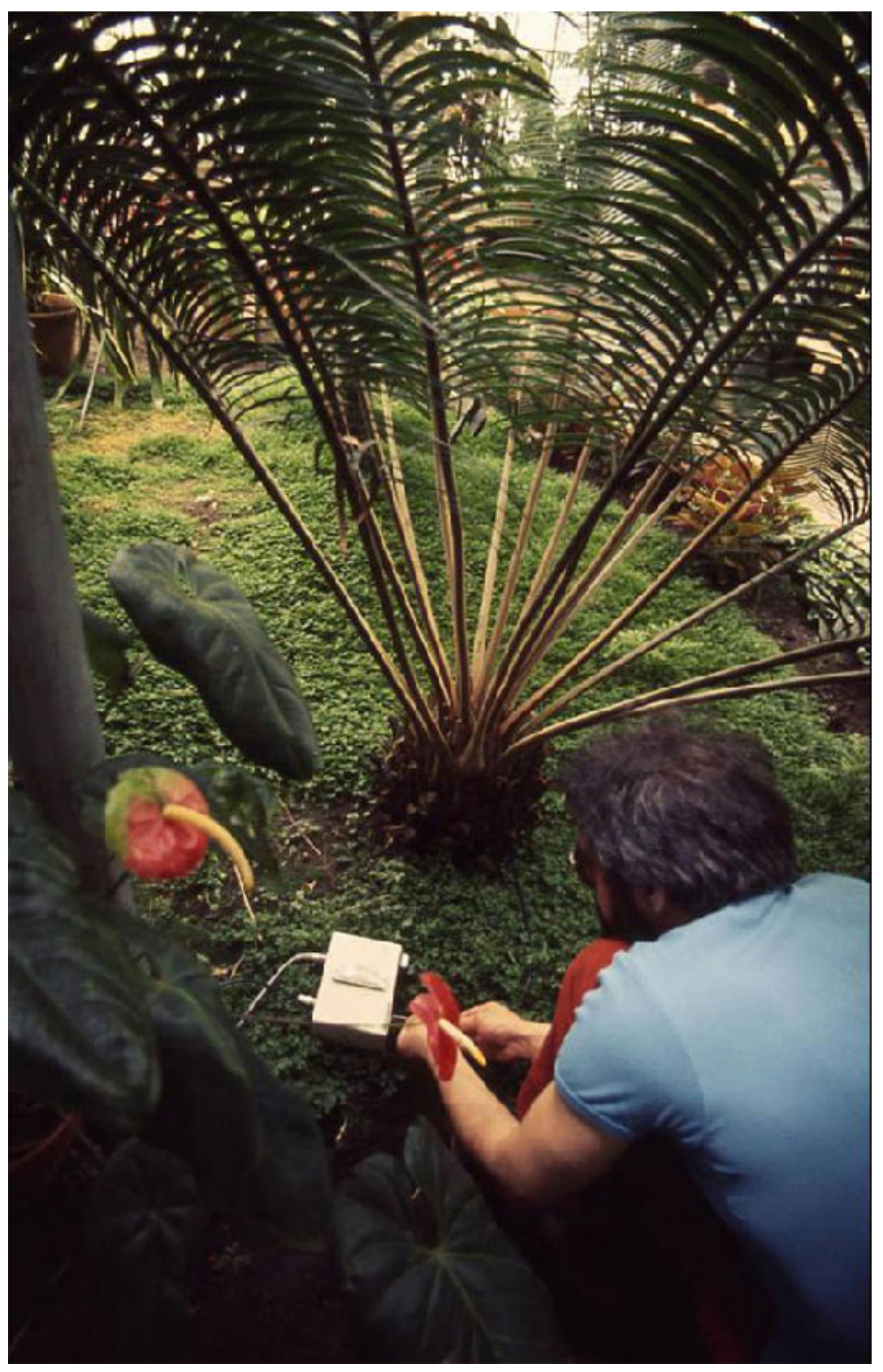


Sonfist or the Harrison's, Green Music has a higher degree of ecological efficacy according to Guattari and Demos because Lifton reaches outside of the art and environmental theme and into that of nature and the psyche.

\section{Redefining Space}

Hildegard Kurt, a researcher of German culture and social sculptures, stated in her article "Aesthetics of Sustainability" that "In the art world lively dialogue is often hindered by the error of seeing sustainability only as an 'environmental subject' and not as a genuinely cultural challenge. ${ }^{, 27}$ Iraqi American conceptual artist Michael Rakowitz generates innovative artworks that creates solutions in the social, political, and economic spheres without attempting to completely restructure current systems. Rakowitz's conceptual art continues to be interventionist to the point of activism. However, unlike early conceptual work he does not attempt to remove commodified culture, but rather resituates and redefines how society commodifies space. This transition in conceptual art from de-commodified art to redefining commodified culture was a reaction to the art market finding ways to sell conceptual work of the $60 \mathrm{~s}$ and 70 s. Often conceptual artists would document their work through film and photographs, which would later be sold. Galleries would also sell the rights for conceptual art that would allow museums and other galleries to reproduce works of art following specific instructions laid out by the artist. This is now a common practice in the artwork of artists such as Félix González-Torres. In Rakowitz's (P)LOT (2004-present) (Figure 10) Rakowitz questions the occupation of public space and attempts to alter how it is commodified. Appearing first in Vienna, Rakowitz offers revolutionary ways in which parking spaces can be reworked and revitalized into rental spaces for various activities.

\footnotetext{
${ }^{27}$ Kurt, Hildegard. "Aesthetics of Sustainability," Ecological Aesthetics. Art in Environmental Design, Boston: Birkhauser, 2004. p. 239.
} 
Figure 10: Michael Rakowitz. (P)LOT (2004-present)

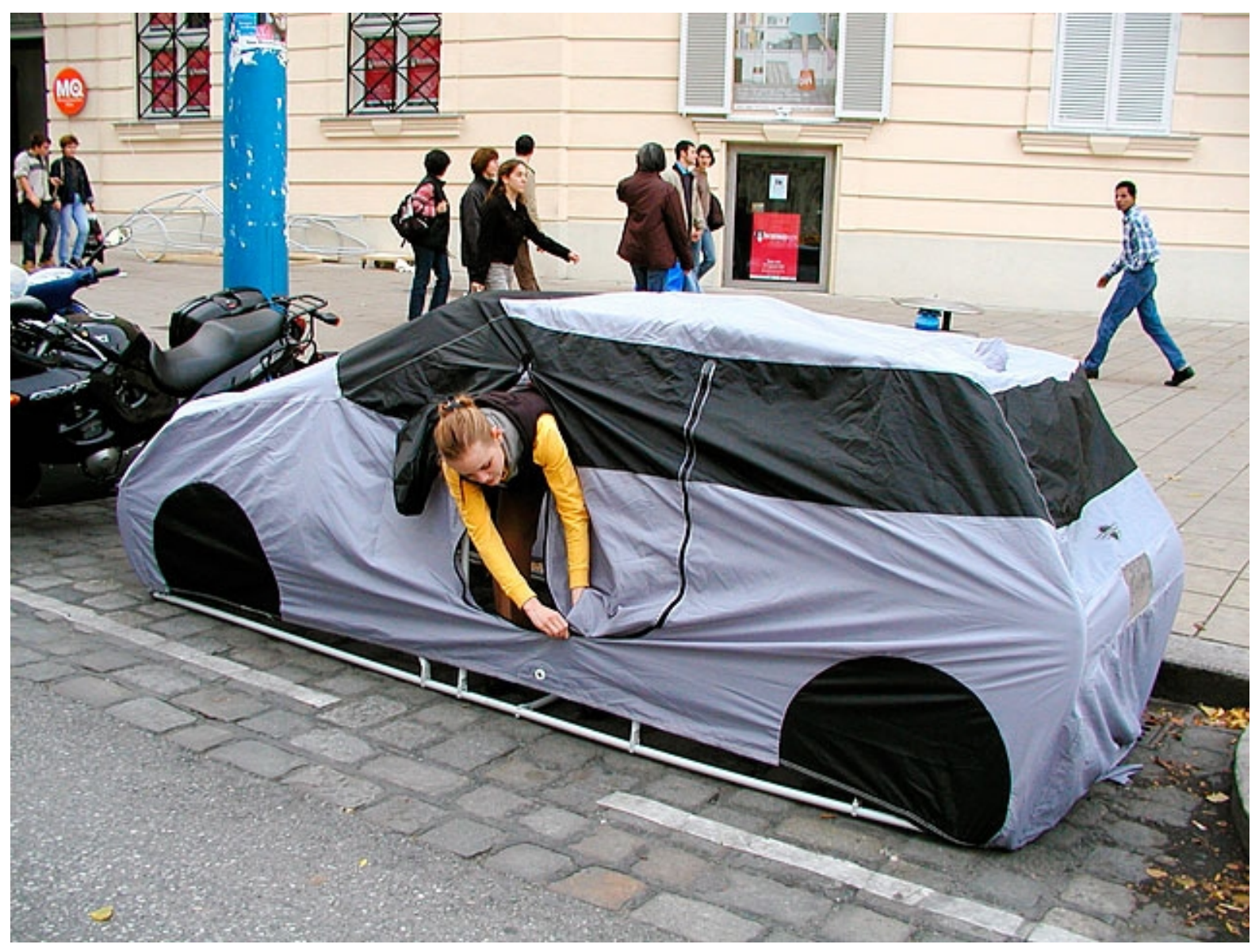


(P)LOT proposes that parking spaces can be rented through meters for various means including game playing for children, living spaces for the homeless, temporary gardens, popup exhibitions, farmers markets, outdoor dining, and more. Rakowitz first presented this work as a portable tent that looked like an ordinary car cover creating a camouflaged leisure space for those renting the region. This work reconsiders how city life functions and formulates questions about the current use of public spaces in rapidly growing cities. How is public space commodified? What is the importance of public space in a crowded city where private space is already so limited? This work neither recreates the past nor removes the responsibility of man from the ecosystem. Instead, Rakowitz makes viewers aware of concerns with growth in cities and offers innovative solutions. While turning a small lot into a commodity might be seen as a negative impact on the ecosystem, it is important to remember that the spaces Rakowitz is suggesting be monetized are those that already have value placed on them. (P)LOT simply suggests that the space should not be used solely for cars, but could be of value for a range of activities. Rakowitz has conceptualized a rental system that would allow someone to rent out a single lot or an entire block with the ease of a parking meter. $(P) L O T$ embodies the transversal thinking that Guattari thinks will redefine systems and aid in establishing a harmony between the ecologies. Unlike Lifton, Rakowitz does not create new technology in order to create transversal artwork, rather he takes an existing structure and reworks it to fit the current needs of the social and mental ecologies.

\section{Questioning Value Systems}

Earth works such as those by Sonfist and the Harrisons create unrealistic narratives by concealing human interactions in systems and limiting their transversal thinking. While Sonfist employs nature as a representation of another time, the Harrisons separate man from 
other systems such as the political and the economic. Both of these projects focus heavily on a single ecology and separate it from other overlapping regions. Danish environmental artist Tue Greenfort's photo series Diffuse Einträge (2007) (Figure 11) focused on sustainability concerns and pointed out the shortcomings in society such as the desire to choose short-term cosmetic solutions over long-term environmental ones. In Diffuse Einträge, Greenfort documents his visits to Lake Aasee in Münster Germany as the city decided how to approach cyanobacteria in the lake and rivers. Lake Aasee is a highly populated recreational area and the cyanobacteria blooms triggered by run off from fertilizer in the agricultural region has caused the water to change colors and is dangerous to humans and wildlife. The city ultimately decided to add a substance called Iron (III) - Chloride to the water in order to alleviate the phosphate levels. This solution is cosmetic, temporary, and untested having only been utilized in water clearing systems. In Greenfort's photo documentation, willow trees surround the lake. It is green and lush while a large metal dispenser stationed near the edge of Lake Aasee sprays gallons of Iron (III) - Chloride directly into the bacteria invested water. In the project, Greenfort notes the issues with the solution stating that it is not sustainable and removes the responsibility of the agricultural industry on the long-term effects of manure in the natural water systems. While Greenfort's artwork is not sustainable, it raises issues with sustainability and reveals the tendency for man to make sacrifices for natural resources before changing habits in the political and social sphere. Greenfort's work reveals the tendency for man to lean towards an aesthetic value rather than taking responsibility for the negative influences that humans have on the ecosystem. The city of Münster has not removed the cause of the phosphates from the water, but has instead masked the effect of man on the environment by pouring more chemicals into a natural water source. Diffuse Einträge 
Figure 11: Tue Greenfort. Diffuse Einträge (2007)

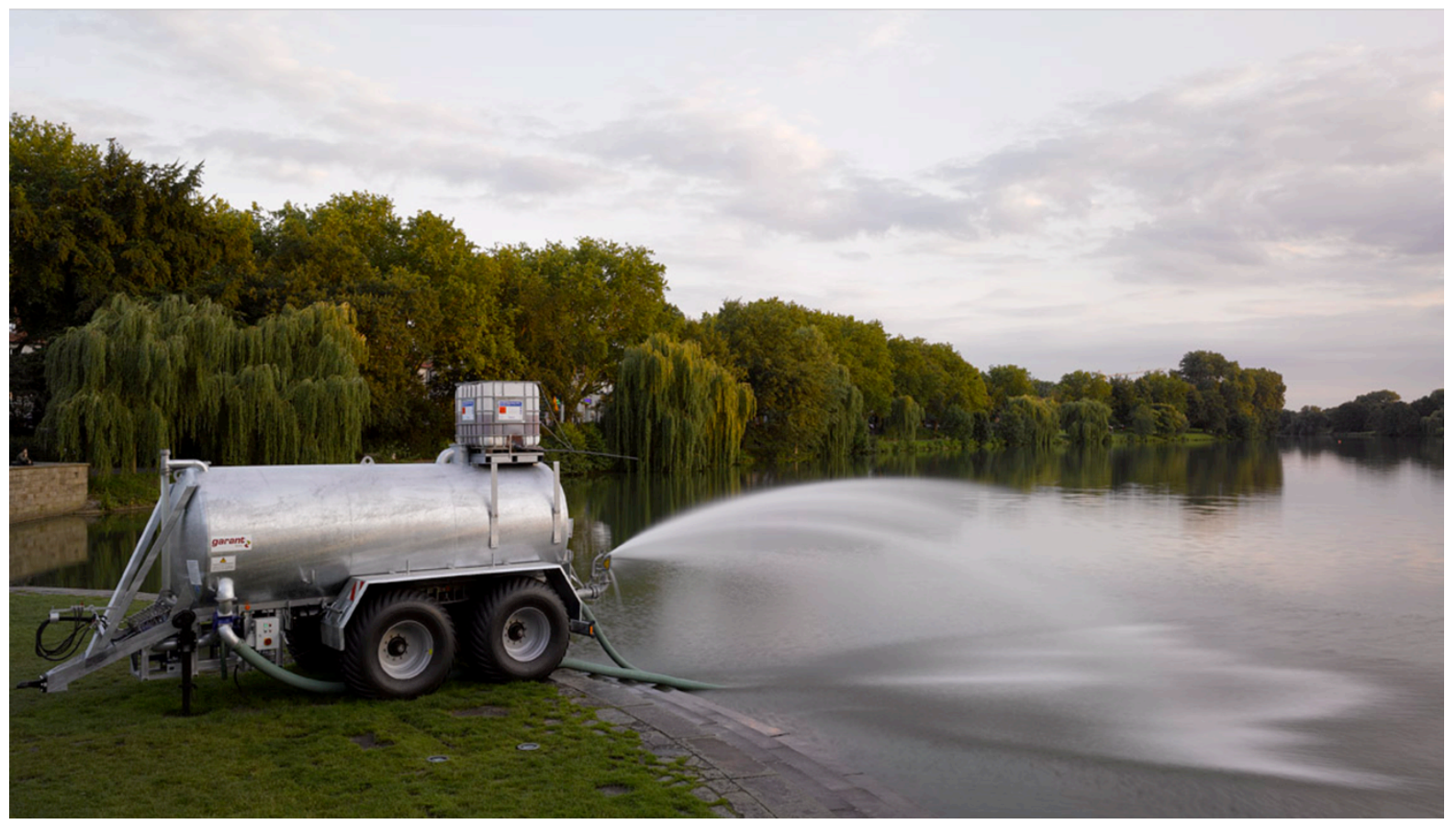


examines more than just the effect of man on the environment, but also investigates our most basic value systems through an interdisciplinary and transversal mode of critical exploration. Greenfort hoped that this local project would act as a lesson for larger contemporary issues such as the impact that the meat industry has not only on water systems, but also on air quality and other contributing environmental factors.

\section{Interdisciplinary Criticality}

The artists in this chapter display different degrees of ecological efficacy in their artworks. Those that separate man from nature or attempt to place human involvement in a closed system has less efficacy. They focus more on the aesthetic and unrealistic scenarios that could not be replicated on a large scale in order to effect ecological change. The work of Lifton and Greenfort expose human-involvement in ecology by using interdisciplinary approaches such as those between nature and the psyche, agriculture and pollution, and man and the environment. Greenfort questions the core value systems that we hold and how ecologies play into those structures. Rakowitz also has a high level of ecological efficacy by creating a transversal artwork that also utilizes pre-established systems in society. Rakowitz tests the limits of space and redefines commodity culture by restructuring how citizens consume public space. Further investigated in the next chapter, human-system involvement and interdisciplinary approaches can redefine language, representation, perspective, time, and place. In a closed system, artworks would not be able to function as a representation of another region, nor would they be able to take part in an interdisciplinary discourse. The interconnectivity between regions in various systems establishes the foundations of language, materiality, place, and time in the ecosystem. Without these connections, artworks would be one-sided and would remain in one sphere of existence. As artists test the limits of systems 
and investigate the overlapping regions in them, the viewer is able to create further connections between otherwise seemingly unrelated or disconnected themes in order to contemplate artwork from an interdisciplinary approach. 


\section{CHAPTER III}

\section{THE REFERENCE OF RUBBLE}

"The most beautiful world is like a heap of rubble tossed down in confusion." -Heraclitus, Fragment 124

Artists that recognize the inextricability of human involvement in systems began challenging regions of intervention through a fascination with disrupting the earth through either the displacement or addition to the natural landscape. Destruction and construction are prevalent in the work of earth artists concerned with time, place, and the viewer's perspective in terms of material and scale. The work of such artists suggests that the devastation and appropriation of a landscape often creates a more complex discourse about place and material than the original structure. As sculptors became intrigued by the materials that existed outside of the studio space, artists of the 1960s and 1970s not only migrated their workshops outdoors, but they found ways to bring the natural world, specifically soil, rocks, salt, and wood into the gallery space. Due to the dissociation or restructuring that occurs when removed from their original site, natural materials such as soil rely on a common conceptual ground to transform in the eyes of the viewer. As artists removed materials from their original site and intended function, the sculptures of the artists in this chapter transform their artwork from the visual to the verbal. The materiality of these sculptures shifts the work from the ecological region of the natural physical world into one of linguistic representation through transversal approaches. As discussed in chapter two, human-system involvement 
creates a foundation for invoking contextual meaning in a work of art. Language, material, place, and time are all constructs established through the human perspective in response to existing environmental, political, and economic systems. This chapter focuses on the sculptures of Robert Smithson and the evolution of sculpture between the 1960s and 1970s in relation to his work. In this chapter, Smithson plays with the boundaries of established structures to reframe and decontextualize physical material in order to reposition his sculptures as a form of dialect.

As artists explored new materials, it became more difficult to define sculpture in historic terms. Sculpture was no longer about what was in the gallery space, but about what was missing and about the materials employed. In Krauss' "Sculpture in an Expanded Field," she develops the definition of sculpture to include "architecture" and "not-architecture" and "landscape" and "not-landscape." ${ }^{28}$ Sculptures that expanded into the region of landscape are defined and situated by their site, whereas sculptures that intervene in architecture are identified as not-landscape. Prior to the 1960s modernist sculpture was defined, in her formulation, as either architecture or landscape. Either the artwork could exist as an industrial form or in opposition the sculpture could be a part of nature. According to Krauss in the late 1960s this definition evolved to include the limits of those terms. This meant that not-architecture was interchangeable with landscape and not-landscape could represent architecture. As a result of these intersections, sculpture was no longer stuck in a binary discourse, but could take part in the intersecting regions between landscape and not architecture and not landscape and architecture. Krauss wrote in "Sculpture in the Expanded Field," that:

${ }^{28}$ Krauss. "Sculpture in the Expanded Field." p. 37. 
As the 1960s began to lengthen into the 1970s and 'sculpture' began to be piles of thread waste on the floor, or sawed redwood timbers rolled into the gallery, or tons of earth excavated from the desert, or stockades of logs surrounded by firepits, the word sculpture became harder to pronounce. ${ }^{29}$

Artists such as Iain Baxter challenged the limits and boundaries of sculpture by playing with established systems and structures. Baxter created a Portfolio of Piles (1968) (Figure 12) that featured images of found objects. His Piles feature large constructed mounds of material utilized often in industrial settings. Baxter's Piles show a concern for the material by allowing the form of each object to dictate the shape and definition of the "pile." There is a balance between chaos and order in Baxter's pyramids. Every found pile has been intentionally stacked, yet the unique characteristics of the chains, wooden poles, and gravel are organized in a manner that is established by the material. For example, there is a distinct difference in the aesthetic and limits of a pile of boxes versus the boundaries established by a stack of steel pipes. While the boxes are easily stackable, the steel pipes often need physical restraints in order to remain in an organized pile. Baxter resituates objects used in industrial construction to create sculptures that acknowledge the predefined conditions and limits of each material to highlight how matter can function independently of established systems when disrupted.

As artists explored materials outside of the studio, they began manipulating natural materials in ways that stretch the definition of sculpture. Earth artists of the 1960s and 1970s identified limits of natural materials and recognized that they exist in a system that escapes the social structures of traditional sculpture. When incorporating earth into a sculpture, time, place, and perspective become inherit in the material. By the beginning of the 1970s sculpture, according to Krauss had opened new possibilities to contemporary definitions of

${ }^{29}$ Krauss, Rosalind. "Sculpture in the Expanded Field," p. 30-44. 
Figure 12: Iain Baxter. Portfolio of Piles (1968)

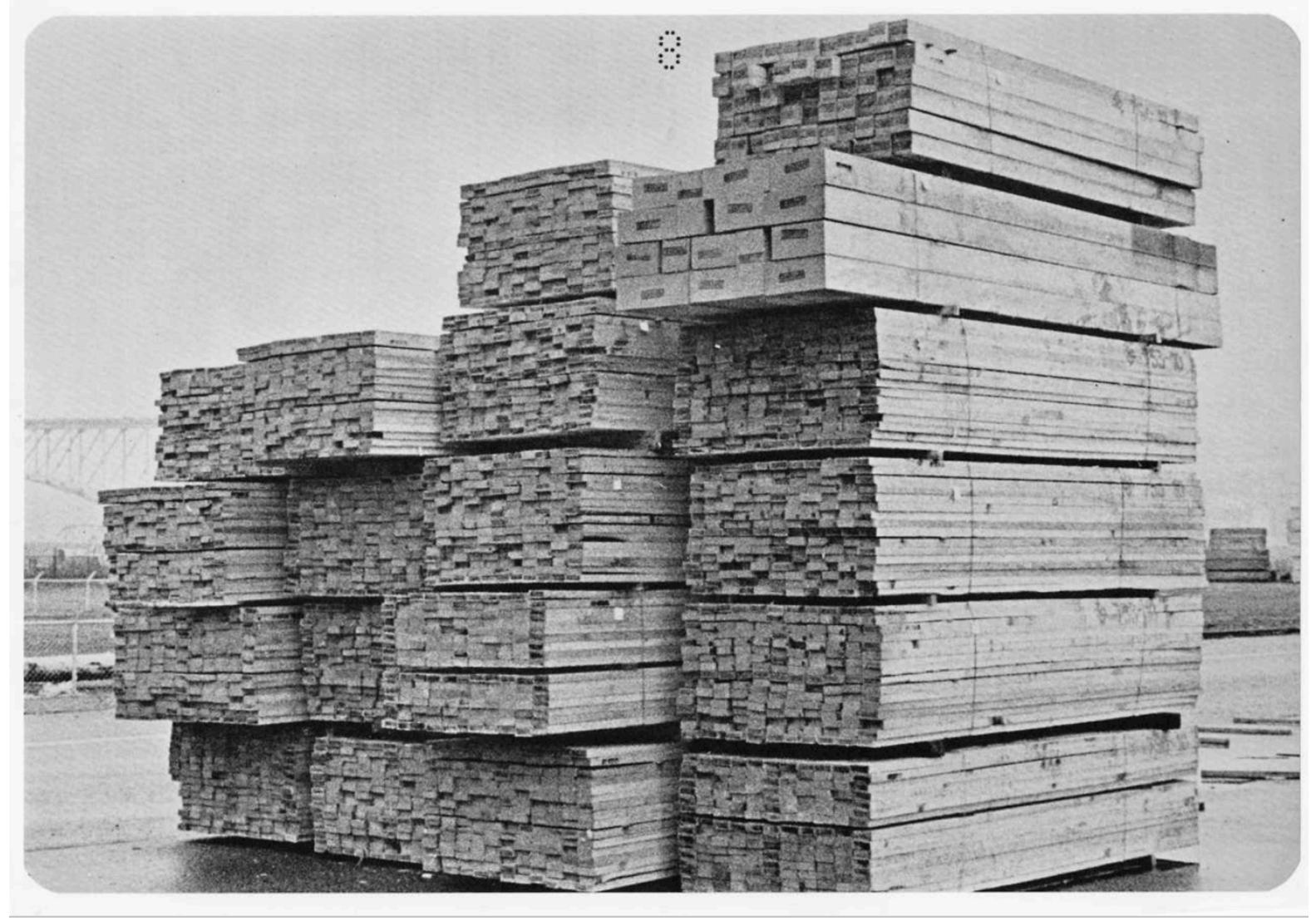


sculpture. Artists like Robert Smithson began creating artworks that took place between landscape and architecture, architecture and not-architecture, and landscape and notlandscape. As termed by Krauss, the sculptures like Smithson's that fall between the landscape and the not-landscape are defined as marked sites to capture the artworks that physically manipulate sites. ${ }^{30}$ In "A Sedimentation of the Mind: Earth Projects," Smithson states that:

In order to read the rocks we must become conscious of geologic time, and of the layers of prehistoric material that is entombed in the earth's crust. When one scans the ruined sites of pre-history one sees a heap of wrecked maps that upsets our present art historical limits. A rubble of logic confronts the viewer as he looks into the levels of the sedimentations. The abstract grids containing the raw matter are observed as something incomplete, broken, and shattered. $^{31}$

The destruction or removal of land, leads to the construction or resituating of natural materials. Rock Salt and Mirror Square I (1969) (Figure 13) features what Smithson classifies as a site and a nonsite at the Cayuga Salt Mines near Lake Cayuga in New York. For the site-specific work, Smithson went into the salt mines and randomly placed twelve mirrors in the mineshaft. The mirrors created a chaotic environment in the mine reflecting ore in an already claustrophobic area. The mirrors and Smithson's random placement was also reminiscent of the chaos, disorder, and genuine luck that comes with mining. In the nonsite, Smithson removed rock from the mines and used it to create an installation at Cornell University. In the gallery space, rock salt fills the room and reflects off mirrored containers. At the center of the gallery is a square container with mirrored interior and exterior sides. Smithson mimics the original site of the Cayuga Mines by removing sharp

${ }^{30}$ Krauss. "Sculpture in the Expanded Field," p. 41.

${ }^{31}$ Smithson, Robert., and Jack D. Flam. "A Sedimentation of the Mind: Earth Projects." Robert Smithson, the Collected Writings. Berkeley: University of California Press, 1968. Print. The documents of twentieth-century art; Documents of 20th century art. p. 110. 
Figure 13: Robert Smithson. Rock Salt and Mirror Square I (1969)

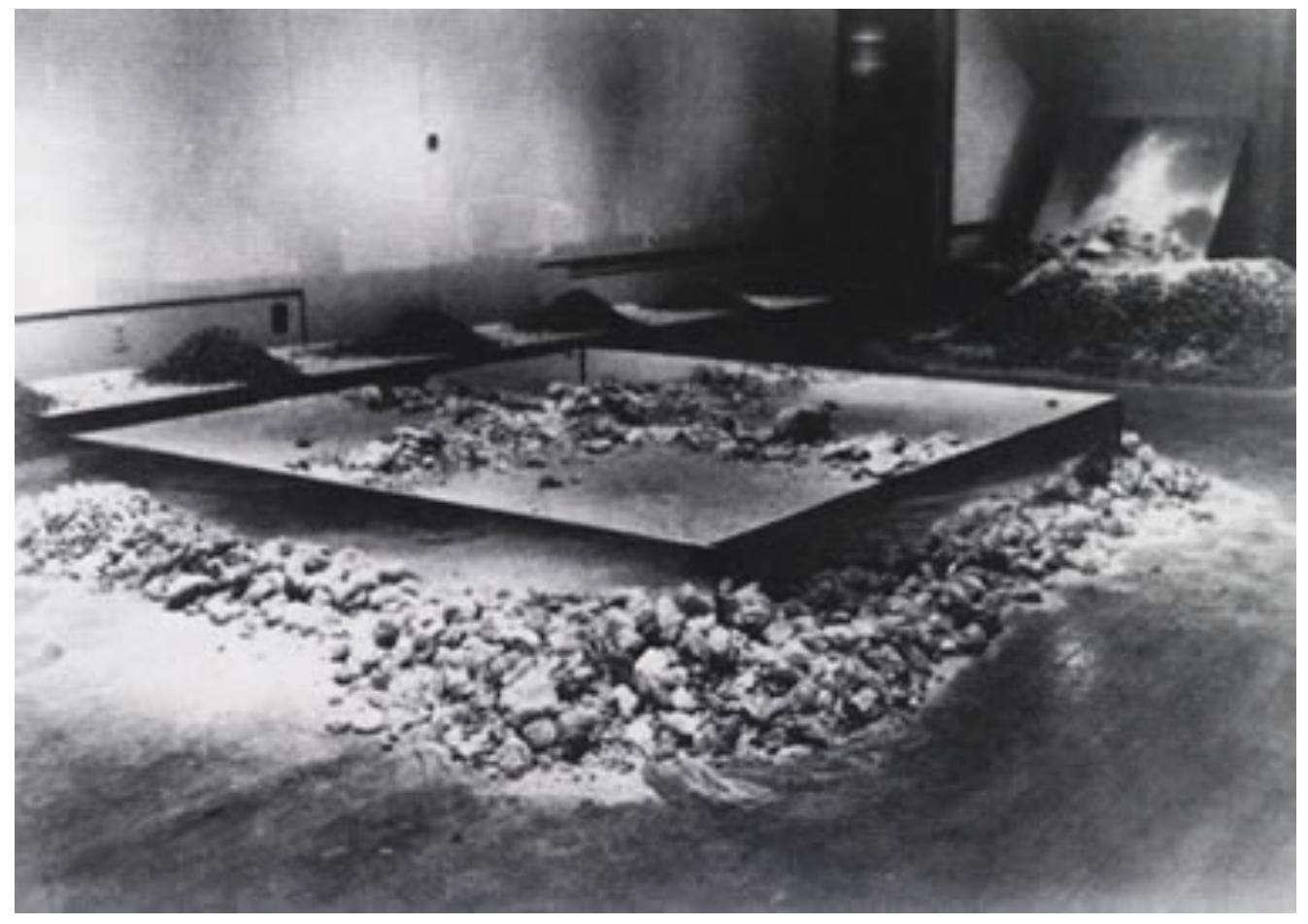


ninety-degree angles from his containers. Rock salt piled along the internal and external walls of the mirrored container create the illusion of infinite piles of rock while also disrupting the harsh angles of the box. Smithson's installation mirrors that of a mine by incorporating reflective surfaces into the display. On one wall, there is a row of eight square mirrors laying on the floor and looking up at the viewer. Smithson places large mounds of rock salt between each mirror to scatter the image. In Rock Salt and Mirror Square I, Smithson both contains and disperses the material through his use of the mirrors and his dislocation of the original material. The nonsite acts as a map to the original site allowing a pile of rubble to contain the reference of its original location.

Smithson's nonsites act as a representation of the site transforming ordinary materials such as rock and soil into a signifier for a specific region. In Ferdinand de Saussure's essay "General Principles: Nature of the Linguistic Sign," he explains that a linguistic sign has two parts: a concept or the signified and a sound-image or the signifier. ${ }^{32}$ An example of this would be the concept of fire bringing up an image of flames. Saussure would agree that signs are arbitrary, meaning that they are purely conventional, i.e. we know that a four-legged sitting device is called a "chair" in English by learning the language. According to Saussure there is no linguistic connection between a word and the corresponding sign, there is only a learned vocabulary established by a larger community. Saussure theorizes the immutability of a sign in a linguistic community. He states, "The signifier, though to all appearances freely chosen with respect to the idea that it represents, is fixed, not free, with respect to the linguistic community that uses it. ${ }^{, 33}$ This means that while the sign is arbitrary, it is also fixed because it was designated by a greater consensus in the community and there is a set

${ }^{32}$ Saussure, Ferdinand de. "General Principles: Nature of the Linguistic Sign." Course in General Linguistics. n.p. 1916. p. 66.

${ }^{33}$ Saussure, "General Principles: Nature of the Linguistic Sign.” p. 71 
existing language that cannot be broken. While Smithson's nonsite signifier may appear arbitrary to his signified site, he provides context to the viewers through the title of his artworks to establish a common ground, which normally consists of the original location. Michael Tomasello explains the need for a common ground in his essay "A Focus on Infrastructure:"

The ability to create common conceptual ground-joint attention, shared experience, common cultural knowledge-is an absolutely critical dimension of all human communication, including linguistic communication with all of its he's, she's, and it's. ${ }^{34}$

Each rock in the rubble is a reference to another time and place that is dissociated both from the gallery space and from the original location. The site of Smithson's works contains the entire history (both past and present) of the location. When the soil is removed and reframed, it forms what Smithson refers to as a "network of signs." ${ }^{, 35}$ Each rock points to a specific time and place, but only holds a portion of the narrative. The site has no beginning or end and thus the representation holds no signification of a single origin point. Rock Salt and Mirror Square I transforms material it into a reference of language. The rubble acts as a representation for a site that is unreachable both visually and verbally by viewers at the museum. Smithson pays attention to how the different sections (site and non-site) work together and against each other. They act like nodes of a larger network. French philosopher Michel Foucault describes this web of interconnecting parts by comparing it to a novel:

...beyond the title, the first lines, and the last stop, beyond its internal configuration and its autonomous form, it is caught up in a system of references to other books, other texts, other sentences: it is a node within a

\footnotetext{
${ }^{34}$ Tomasello, Michael. "A Focus on Infrastructure." Origins of Human Communication. MIT Press Cambridge: Massachusetts. 2010. p. 5.

${ }^{35}$ Owens, Craig. "Earthwords.” October, vol. 10, 1979, p. 122. www.jstor.org/stable/778632.
} 
network... it indicates itself, constructs itself, only on the basis of a complex field of discourse. ${ }^{36}$

Smithson fills a gallery space with heaps of rubble that translate into words depicting space and time. He compares these ruptures in the narrative of his sculpture to the cracks that open when dissecting language. ${ }^{37}$ There are no origin points, but rather a network of signifiers. Smithson establishes his sculptures as embodying a discourse between systems. His piles resituate and reveal the connections between human constructs such as time and language with the natural materials of the earth's crust.

When Smithson titles one of his artworks Nonsite (Essen Soil and Mirrors) (1969) (Figure 14), he establishes a connection for the viewer between the soil in front of them and the location that it is representing. Nonsite (Essen Soil and Mirrors) features four small piles of dirt separated into quadrats by square mirrors. Due to the reflection on the soil, the resulting image gives the illusion of one cohesive pile of soil. Smithson once again manages to both contain and refract the information displayed for the viewer reaffirming the deconstruction of an origin point and communicating the multitude of narratives that can be extracted from the rubble. When there is an origin point, also referred to as a core within writings about post-structuralism and deconstructionism, there also has to be an inevitable ending. The existence of an origin point limits the discourse and creates a binary relationship between the two structures. The totality, or rather the anticipation of an end, creates the only meaning that exists within structural analyses: that which refers to the limited discourse

\footnotetext{
${ }^{36}$ Michel Foucault, The Archaeology of Knowledge. Vintage, 1972. p. 23.

${ }^{37}$ Owens. "Earthwords." p.124. See, "words and rocks contain a language that follows a syntax of splits and ruptures. Look at any word long enough and you will see it open up into a series of faults, into a terrain of particles each containing its own void."
} 
Figure 14: Robert Smithson. Nonsite (Essen Soil and Mirrors) (1969)

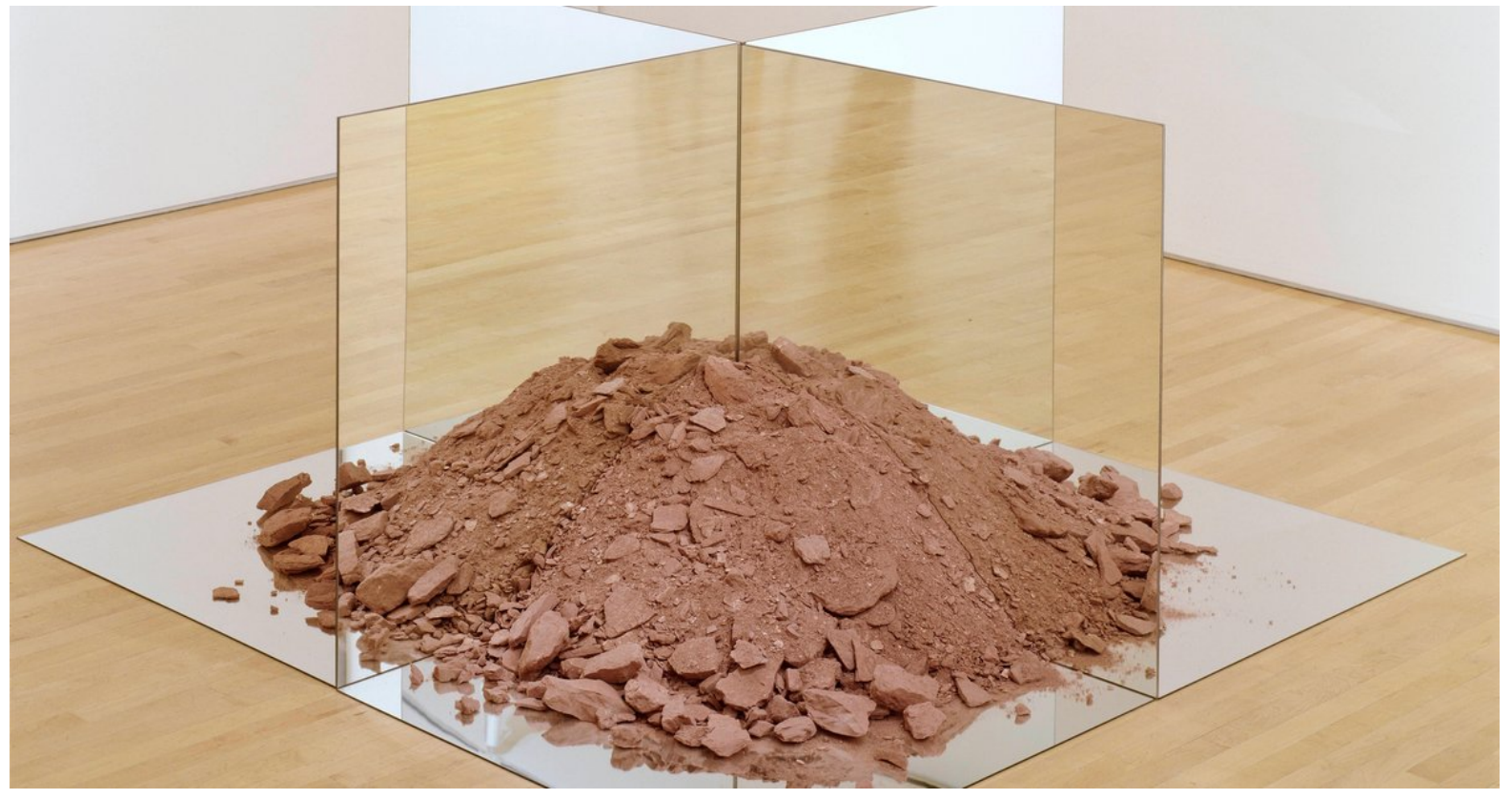


between the signified and the origin. ${ }^{38}$ By deconstructing and disassociating place from materials, Smithson allows the soil to function as reference, just as a photograph of Essen becomes a signifier of the city in Germany. Smithson's nonsites act as fragments that represent a "greater fragmentation." ${ }^{" 39}$ Smithson's nonsite, in this case a pile of disrupted soil, became a reference for a whole image (without a beginning, middle, or end) while also encompassing the act of removal. His nonsites break the mold of traditional sculptural representation. Historically, sculpture concerned with representation was more figurative and sat "in a particular place and [spoke] in a symbolical tongue about the meaning or use of that place. ${ }^{40}$ Although Smithson's sculptures are more abstract in their fragmentation, he still incorporates a type of pedestal into his work in order to clearly define the gallery space from his nonsite. For example, in Nonsite (Essen Soil and Mirrors) Smithson sets the soil on a mirror to create a reflective base that defines the parameters of the sculpture. The sculptures hold meaning outside of the gallery space. The nonsites appear in gallery settings, but they subsist in a linguistic region outside of the physical material and transverse between the site and the nonsite.

Smithson's investigations into the limitations of nonsites led to installations that featured multiple references from various perspectives. Nonsite (Franklin, New Jersey)

${ }^{38}$ Derrida, Jacques. Writing and Difference (Chicago: University of Chicago Press, 1978), p. 26.

${ }^{39}$ Smithson, "A Sedimentation of the Mind: Earth Projects." p. 111. See "The container is in a sense a fragment itself, something that could be called a three-dimensional map. Without appeal to 'gestalts' or 'antiform,' it actually exists as a fragment of a greater fragmentation. It is a three-dimensional perspective that has broken away from the whole, while containing the lack of its own containment."

${ }^{40}$ Krauss, "Sculpture in the Expanded Field." p. 33. See, "By virtue of this logic a sculpture is a commemorative representation. It sits in a particular place and speaks in a symbolical tongue about the meaning or use of that place. The equestrian statue of Marcus Aurelius is such a monument, set in the center of the Campidoglio to represent by its symbolical presence the relationship between ancient, Imperial Rome and the seat of government of modern, Renaissance Rome." 
(1968) (Figure 15) utilizes signifiers in two and three dimensions. The artwork consists of five wooden boxes of varying sizes; each filled with rocks from the site and organized in a pyramidal shape. On the wall behind the sculpture is a photograph of an aerial view of the site, also sectioned into five trapezoids forming a pyramid on the wall. Scale and perspective play a role in this artwork that distinguishes between the types of signifiers. The rocks contained in boxes are disrupted and otherwise disassociated from their site. In this sculpture, Smithson relies on the aerial images to take on the role of the mirrors in his later work. The aerial images reflect the site and give the rocks a specific context that allows them to also act as a representation of the site. The variety of perspectives generates another network of nodes that point to a reference (although the reference, like the non-site has no origin point). While the aerial image informs the soil, which references the site, the site itself does not exist as the ending to the narrative. Instead, the site informs the type of signifiers (nonsites) that can be produced in order to indicate a reference to the original location. Smithson tests the limits of the materials to see how far he can dislocate an object while still indicating the original site. In an interview at Cornell University in 1969 following the opening of the group exhibition that featured Smithson's Rock Salt and Mirror Square I, Dennis Oppenheim stated that he is:

At the point now where I see earth as sculpture-where flying over Earth is like viewing existing painted area or pictorial, painterly surfaces. While on the ground it is more volumetric. It's like walking through sculpture. It's less graphic, more subterranean. Any addition to the ground-any scratch or anything you add-becomes a relational addition. ${ }^{41}$

In Nonsite (Franklin, New Jersey), the two-dimensional nonsite provides viewers with a common conceptual ground that then signifies the three-dimensional nonsite and allows it to become a signifier for the site. Smithson takes a traditionally flat and pictorial representation

\footnotetext{
41 "Earth." Interview by Thomas W. Leavitt. Cornell University. Symposium at White Museum, Ithaca, New York, 1969. Television. Transcript.
} 
Figure 15: Robert Smithson. Nonsite (Franklin, New Jersey) (1968)
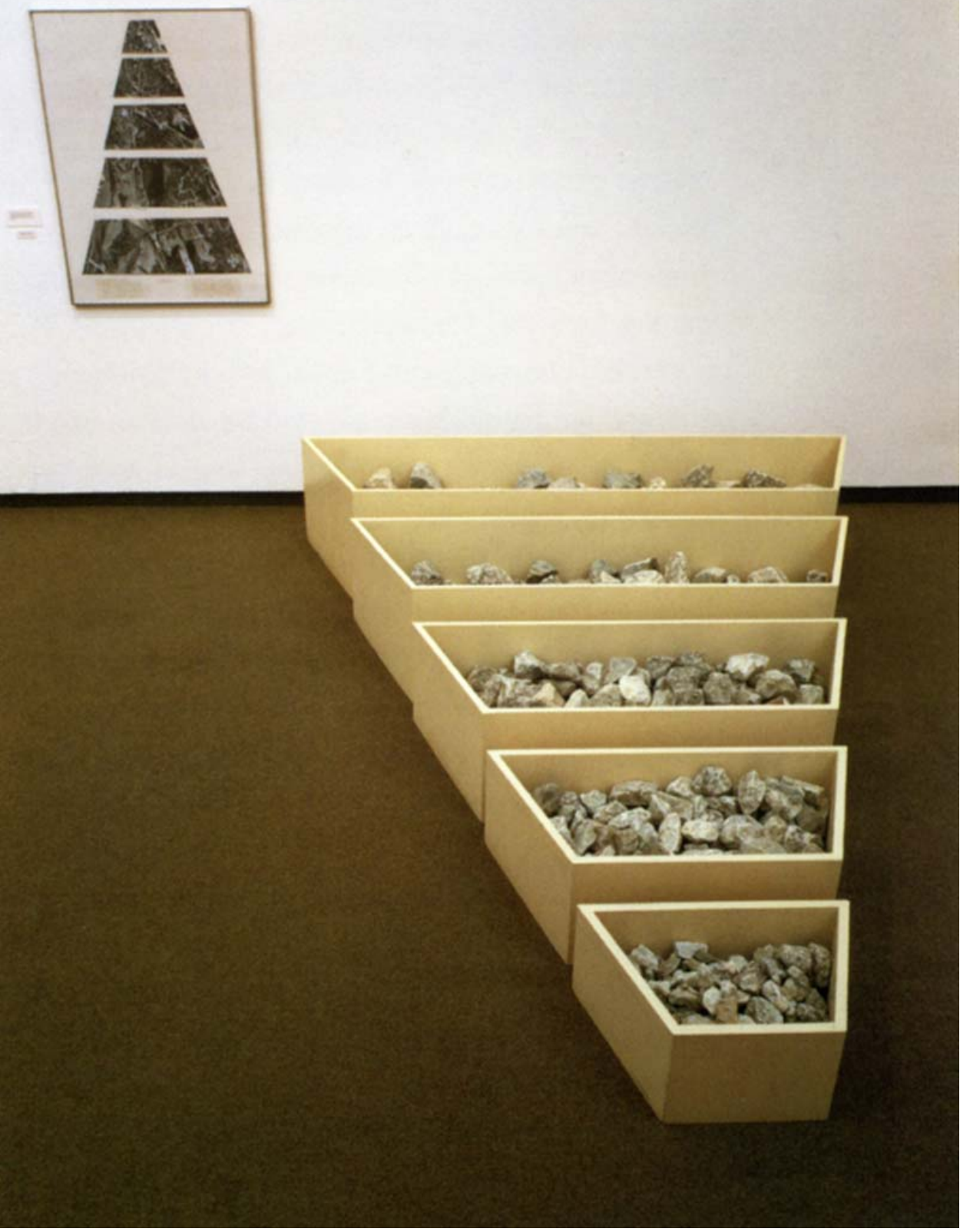
of a site and makes it more representative of a location than the physical material disassociated from the region. He breaks down natural materials into a figure of speech, a metonymy, signified only by visual links that become contextualized through a series of networks.

Smithson's non-sites restructure representation through fragmentation and the need for context in his sculptures. The non-sites contain information that cannot be transcribed by the viewer without a given context. Soil, as Smithson notes in much of his writing, contains data that is referential to a range of specific locations and times. For geologists, soil can tell a detailed story about both the past and present; however, to the viewer without a given context the soil does not extend past its materiality. For the viewer, the materials transform from a pile of rubble to a pile of signifiers in a network of ecological systems. The sculptures transcend the limits of space and material through Smithson's transversal approach. As the visual materials move from one ecology to the other, they become verbal chronicling the history of a region and expanding past perceived constructs of time and perspective. 


\section{CHAPTER IV}

\section{UNSEEN: VISUALIZING ECOLOGICAL SYSTEMS}

This chapter was previously published as a catalogue essay to the accompanying thesis exhibition "Unseen: Visualizing Ecological Systems" January $12^{\text {th }}$-March $17^{\text {th }} 2017$ at the Belknap Gallery in Schneider Hall. The budget (Table 1), checklist (Table 2), floor plan (Figure 29-31) and Press (Figure 32-37) are found in the appendices.

Rivers and other natural pathways are prime examples of how ecological systems intersect and impact one another. Locally, the Ohio River has been plagued with cyanobacteria, which create algae-like blooms in the water that are dangerous to the 5 million people who rely on it. ${ }^{42}$ This bacteria flourishes when certain nutrients, like phosphates, enter the water due to runoff of fertilizers utilized in agriculture. This dangerous anthropogenic bloom can be toxic to wildlife, and has led to reforms in agricultural practices as well as increased costs of water treatment. Economic, political, and environmental concerns emerge when one element is disrupted in these elaborate ecological systems. In Unseen: Visualizing Ecological Systems, Stephen Cartwright and Shohei Katayama demonstrate how such ecologies are entangled. Their work offers a kind of artistic Venn diagram of overlapping regions rather than a scale to be balanced.

Cartwright and Katayama's works act as fragments of the natural world. Social, mental, and environmental ecologies are made real in their sculptures and drawings. This work embodies the intersections between ecological systems and reveal how such systems

${ }^{42}$ Lofton, Kara. "It's Not Just Lake Erie. The Ohio River Has A Major Algae Problem, Too." WESA Pittsburgh's NPR Newstation. NPR, 18 Nov. 2016. Web. 20 Nov. 2016. $<\mathrm{http}: / /$ wesa.fm/>. 
cannot be disentangled. Indeed, theories of systematic ecology incorporate the idea that no organism, human or non-human, can function in a sole ecological system. ${ }^{43}$ Human societies function much like the colonies of insects in a rainforest in that each organism contributes to the function of the whole. Colonies and societies both rely on stable environmental, social, and mental systems in order to operate without disruption. When disruption in routine occurs it can affect the totality of the aggregate structures.

Ecologies, as discussed by French psychotherapist Félix Guattari in his book The Three Ecologies (2008), are independent and autonomous systems, yet the impact and evolution of each system is contingent on the influence of the others. ${ }^{44}$ The term "ecology" often prompts discussions about the environment and focuses solely on the systematic transference and existence of energy in the natural world. Environmental ecology recognizes the coaction and reciprocity that takes place in various ecosystems. Ecology takes into consideration the role of a microbe in the continuing function of a structure. Guattari's three ecologies assert that mental and social structures can also be understood through the framework of environmental ecology. In a society, each person takes on a role that contributes to the continued behavior of the system and, depending on one's status, the impact can take place at a familial or global level. Due to the complexity of systems, it is impossible to find them divorced from one another. Environmental changes can occur by first altering mental and social systems, just as our social practices adapt based on a growing knowledge of environmental systems. The influence of the honeybee on the human diet

${ }^{43}$ Guattari. The Three Ecologies. p. 29. See, "Now more than ever, nature cannot be separated from culture; in order to comprehend the interactions between ecosystems, the mechanosphere and the social and individual Universes of reference we must learn to think 'transversally.' Just as monstrous and mutant algae invade the lagoon of Venice, so our television screens are polluted, saturated, by 'degenerate' images and statements."

${ }^{44}$ Guattari, The Three Ecologies, p. 29. 
through their pollination of crops and the growing concern over the use of pesticides that has greatly decreased the population of colonies is an example of this intersection between ecologies.

Cartwright's work functions as a self-portrait composed of data from his routine activities. These portraits attempt to comprehend the impact that environmental systems such as temperature, precipitation, and wind patterns have on the mundane aspects of his life. Since 1999, Cartwright has recorded over 150,000 data sets in order to compile information about his location, activity levels, forms of activity, and mental health. Through analyzing various patterns, Cartwright gathers information from his extensive catalogue to examine, for example, the impact that a single weather event may have had in the larger scope of his existence.

In Cartwright's "Floating Data" series, he creates colorful graphs encased in a transparent acrylic that features data collected between 2014-2015. Human Powered Outdoor Activity and Temperature 2014-2015 (2016) (Figure 16) explores the correlations between exertion and condition. This work acts as a journal entry not only recording but also contrasting two systems of energy. Cartwright's sculpture indicates the steady link between temperature and human activity—as temperatures climb so does human activity. However, at the extremes of summer, human outdoor activity plummets below even the most moderate of summer temperatures. On the East coast the heat of summer is accompanied by complete exhaustion. The resulting low activity levels lead to less travel and more time spent inside and thus to higher electric bills. The sculpture is also indicative of Cartwright's region and the difference in environmental, social, and mental ecologies based on geographic location. The high temperatures of summer and the lows of winters are different not only globally, but 
Figure 16: Stephen Cartwright. Human Powered Outdoor Activity and Temperature 20142015 (2016).

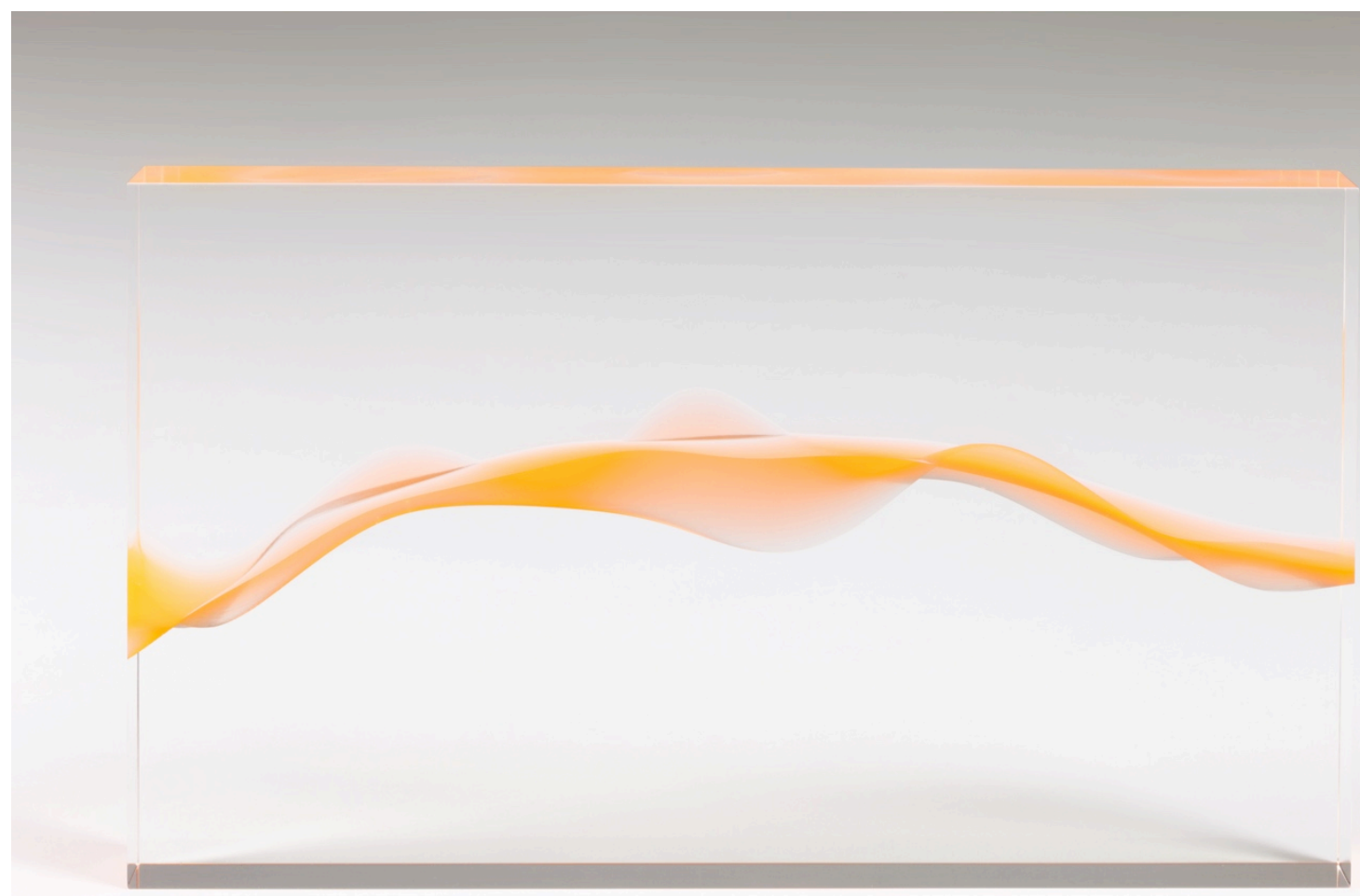

*Image Courtesy of Will Arnold 
also nationally, and can impact the outdoor work completed by farmers, construction workers, and other laborers.

In a more introverted sculpture, Human Powered Outdoor Activity 2014-2015 (2016) (Figure 17), Cartwright stacks two graphs that use shades of purple to provide a history of the artist's time, location, and energy. The graphs run parallel and are suspended in the structure to create a clear visual correlation and to distinguish the regions in which changes occurred between the two years. These snapshots of Cartwright's life are autobiographical in their documentation of not only his movements, but his daily decision-making. The sculptures represent only a small portion of the actual work being conducted while the main body of work exists outside of the gallery walls. Cartwright's incessant data mining and his acknowledgment of the complexities of existing systems operate as a site-specific work in his daily activities.

The historical precedent for such work can be found in the land interventions of Robert Smithson. His Spiral Jetty (1970) (Figure 18), a 1500 foot long spiral made out of rock and dirt in Utah's Great Salt Lake, was a significant marker not only for Earth artists, but for post-minimalism. Minimalism of the 1960s examined the viewer's experience and brought art into the space of the viewer from the detached sculptures on pedestals and gallery walls. Minimalist sculptures involved a lived experience of the viewer and forced them to encounter an object that was not directly accessible through a complete reference. The work created limitations between the viewer's language and the visual and was thus critiqued 
Figure 17: Stephen Cartwright. Human Powered Outdoor Activity 2014-2015 (2016)

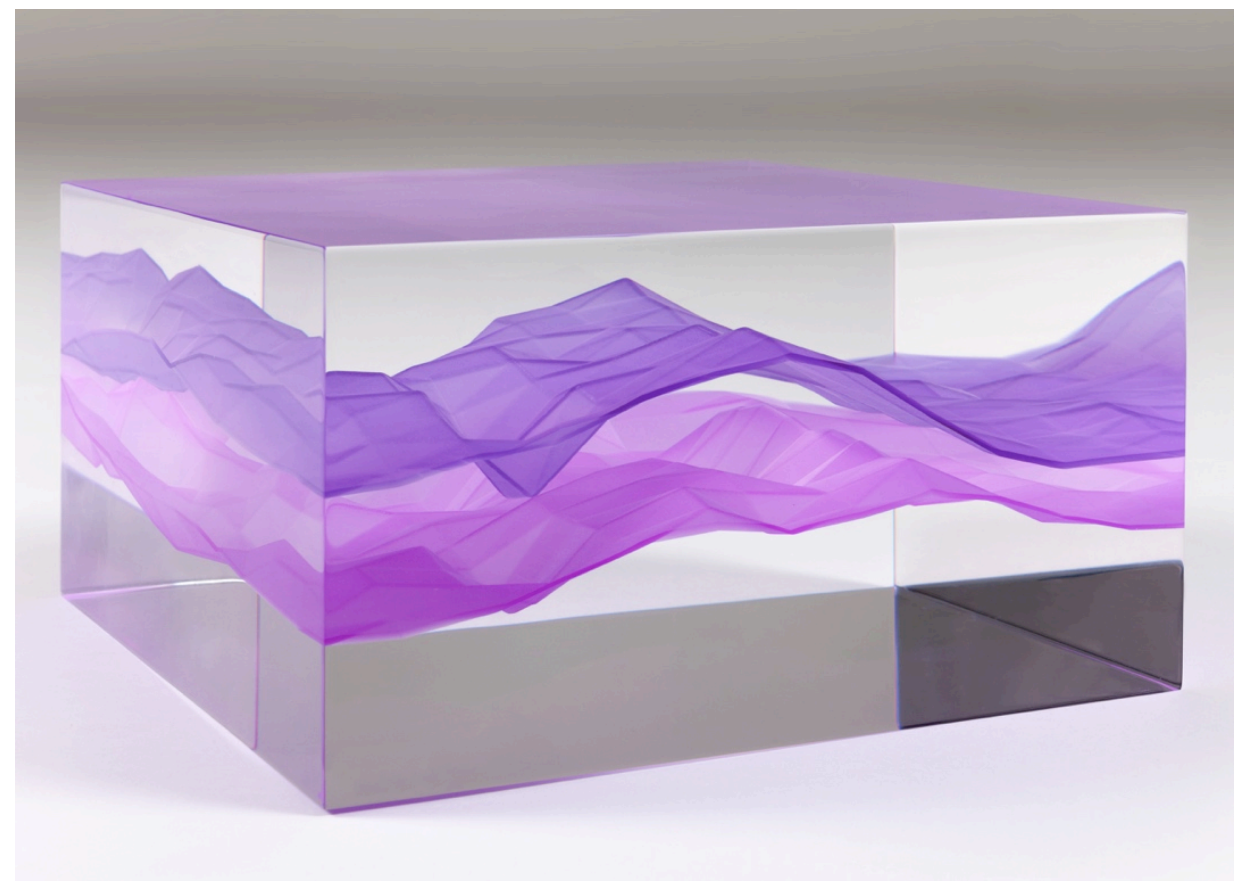

*Image Courtesy of Will Arnold

Figure 18: Robert Smithson. Spiral Jetty (1970)

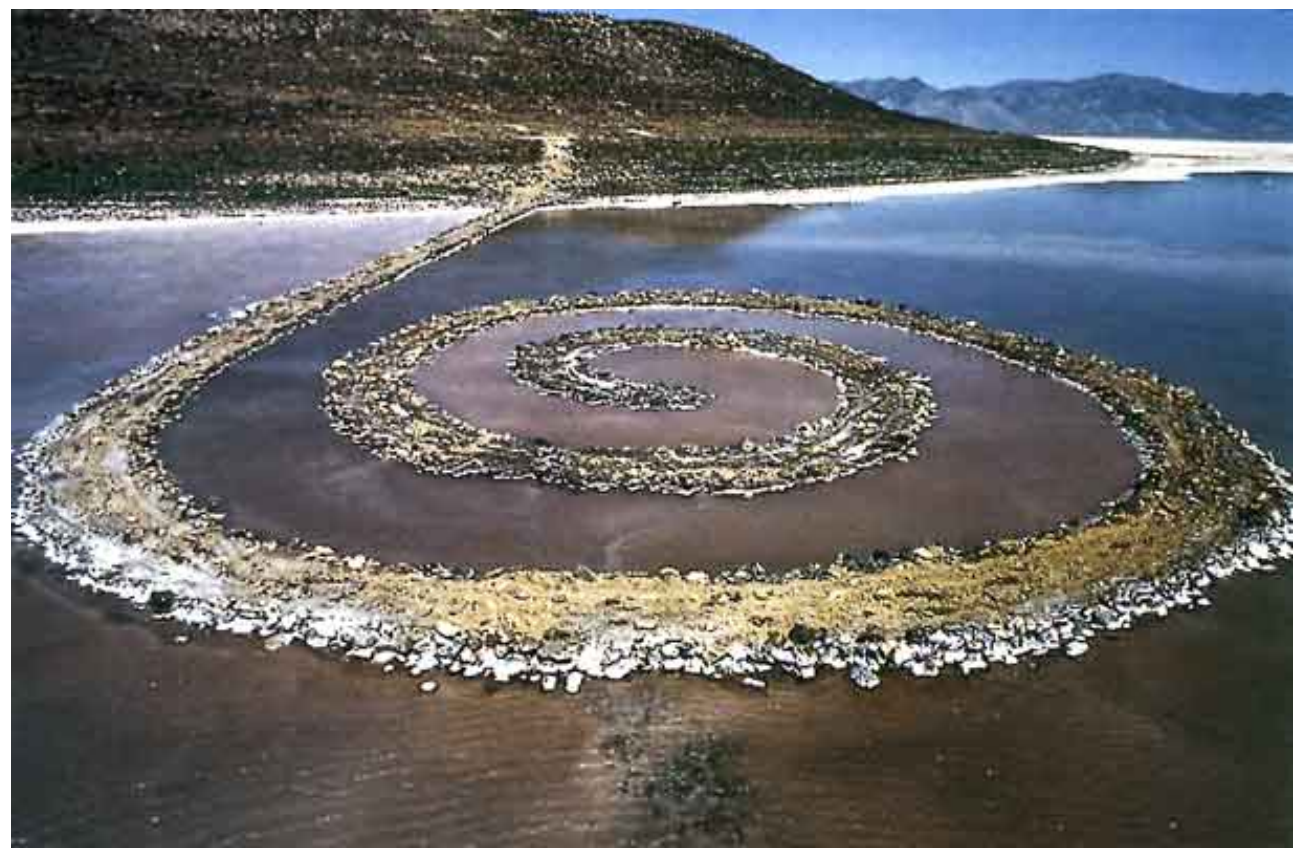


through actively experiencing the work. ${ }^{45}$ Minimalism compelled the viewer to take part in a new form of exhibition experience that allowed them to confront art from innovative perspectives. Smithson's post-minimalist sculptures grew out of minimalism with a continued interest in the material and human experience, but also persisted in further breaking down the formal critiques of sculpture. He took work out of the gallery setting and integrated sculptures into nature. The Earth art created at the time was focused on sitespecific structures and used natural materials found on location. Earth artists strived to create a purer form of art that was free from becoming a commodified object for the growing art market (although documentation of the works often become commodified). The Earthworks created by Smithson held an energy that work displayed in a gallery did not. The site, scale, temporality, and materiality of the work challenged received notions of "art objects." In Smithson's essay “A Sedimentation of the Mind: Earth Projects" (1968) he states that "the sculptor prefers to see his art indoors, but the fact that his work ended up where it did is no excuse for thoughtlessness about installation. The more compelling artists today are concerned with 'place' and 'site'." ${ }^{46}$ Smithson used photography and film to document his temporary Earthworks, allowing him to display an aspect of these site-specific projects in

${ }^{45}$ Fer, Briony. "Judd's Specific Objects," On Abstract Art. New Haven, CT: Yale University Press, 1997, p. 149. See, "As we have seen, Judd used colour to help secure that sense of an overall value of the object. The object is on the floor; it is not seen in relation to a base or pedestal; it is seen for what it is, an object with an inside and an outside. The exposure of an inside simply reveals what is there, nothing is dissembled. But what this description fails to account for is something akin to Fried's duration, the succession of moments at stake in viewing Judd's objects. The sense of duration that I want to suggest here is one where each successive viewpoint on the object has the effect of cancelling another [...] Seeing 'from the front' means not seeing the other perspectives, means making them invisible; so many perspectives are destroyed just as they are created, cancelling each other out [...] For every property that is 'specific' and definable, there is another aspect which escapes that description."

${ }^{46}$ Smithson. "A Sedimentation of the Mind: Earth Projects" p. 104. 
galleries. He called this form of art "Non-Site." Smithson indicates a discrepancy between how his Site and Non-Site works are consumed by the audience and situates this response in terms of disparities in energy between the object and its representation. Smithson's sitespecific works include those that are actively evolving, subject to time, and enhanced by their location. The Non-Site documentation is static and separate from the actual occurrence and does not maintain the same energy that the Site work held due to its temporality. Non-Sites act as fragments of the sited artworks, fragments that can be digested in the gallery's walls. Cartwright's data visualizations operate in this same manner. The site-specificity of his sculptures occurs in the ritualistic recording of data. The sculptures act as a form of documentation and become a non-site representation of his daily actions.

Cartwright's kinetic sculpture Chromatic Data Oscillator (2016) (Figure 19) serves as a vehicle for transcribing information into a visual form and becomes a mode of delivery rather than a subject of traditional aesthetic discussion. The electronic sculpture features moving rods with multi-colored light-emitting diodes (LEDs) on the end that undulate and change colors according to the input data set. The work translates data based on the angle of the rod and the color of the ball head. He has utilized a range of data sets including his daily meditation times in 2016 in correlation with his daily average meditation times overall and analyzes how his mental ecology has evolved. The oscillator becomes a frame that holds the content of Cartwright's work - an active analysis of his space, decisions, and objectives in the everyday.

These sculptures create an echo of his life that is quantifiable and stripped away from the human life that it mimics. These dehumanized sculptures are created by compressing the intricate details of everyday life into a graph in order to comprehend the ways in which 
Figure 19: Stephen Cartwright. Chromatic Data Oscillator (2016)

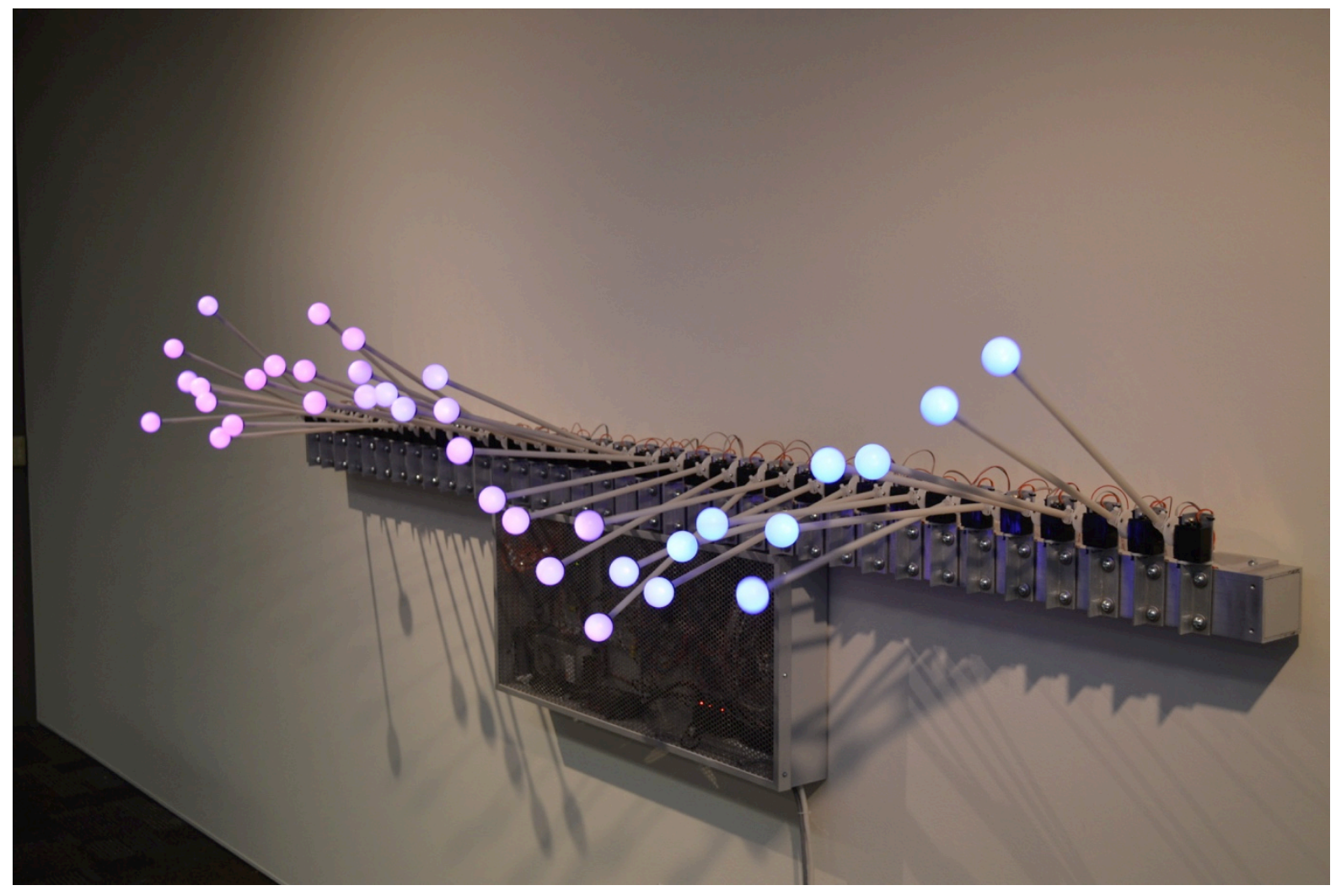


various ecological systems interact. Bed Time Single Set Data 2012-2014 (2015) (Figure 20) is a topographical map of Cartwright's sleeping patterns, which documents an extensive list of late nights, major life events, stressful weeks, vacations, and beyond. This map registers when Cartwright went to bed and woke up every day of the week for two years, revealing the uniformity of 104 Tuesday nights and the sporadic behavior of the artist's weekends. The work creates a code that cannot be easily read in the scope of a single day, rather it asks the viewer to dismiss the small fluctuations in order to appreciate the beauty, power, and determination of routine. No one ecological factor contributes to the routine of human sleep schedules. Human beings are not nocturnal yet we have the ability to set our own internal clock. Those in the emergency medical field, defense, transportation industry, or academia have multiple factors that determine their sleep schedules. Fluctuations in mental ecologies also take part in irregular sleep schedules due to such conditions as stress, depression, and insomnia.

Cartwright's sculptures have shifted focus since 2008 when he first began creating a series of "Lost Landscapes" featuring topographic representations of environments that have been altered due to human intervention. The blue acrylic sculptures of Fort Peck (2008) (Figure 21) and Sakakawea (2008) (Figure 22) features layers of the existing surface area of these two lakes over a time span showcasing the effects that man can have on the environment. "Lost Landscapes" and other works by Cartwright such as 2030 (2009) (Figure 23), which visualizes the predicted decay of snowpack on Mount Kenya, emphasize the large-scale impact of human intervention on natural landscapes. Cartwright's most recent work resituates the responsibility and recognition of these impacts onto the viewer. Often in works that discuss ecology and the anthropogenic shifts in the environment, the viewer 
Figure 20: Stephen Cartwright. Bed Time Single Set Data 2012-2014 (2015)

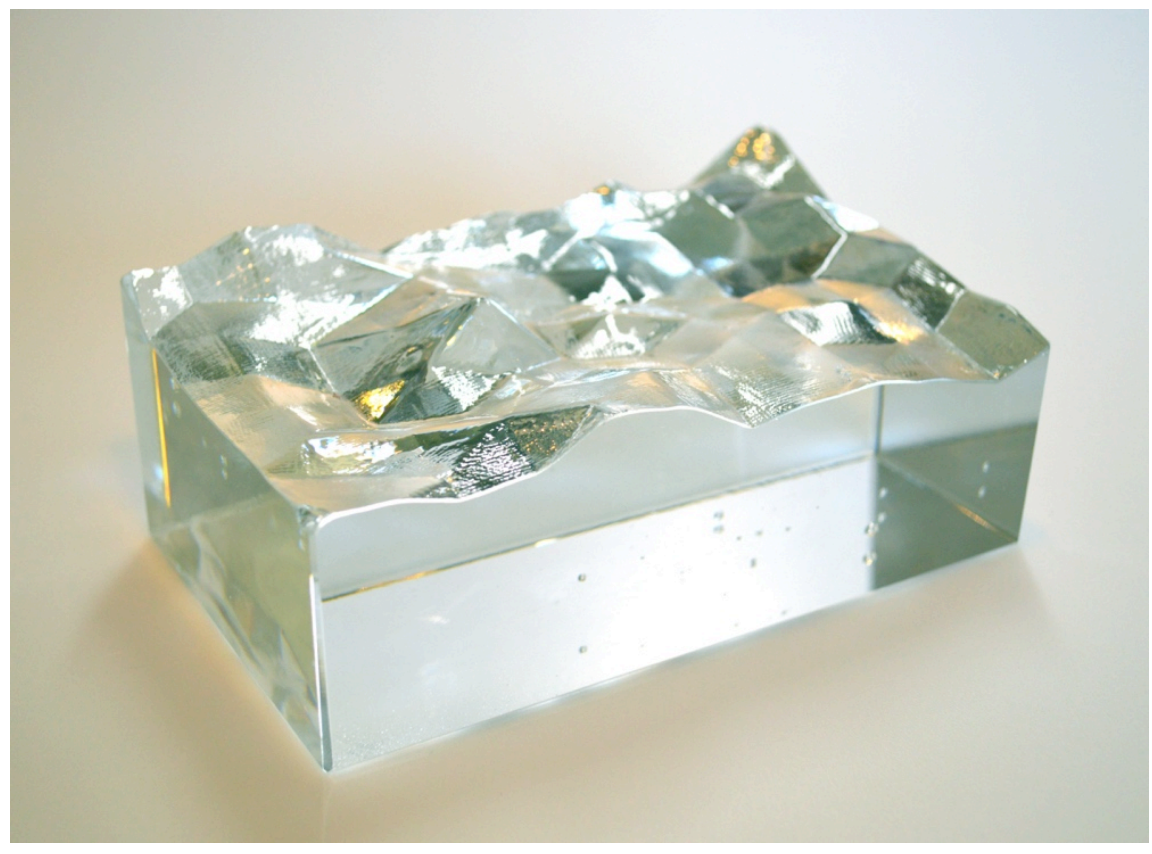

Figure 21: Stephen Cartwright. Fort Peck (2008)

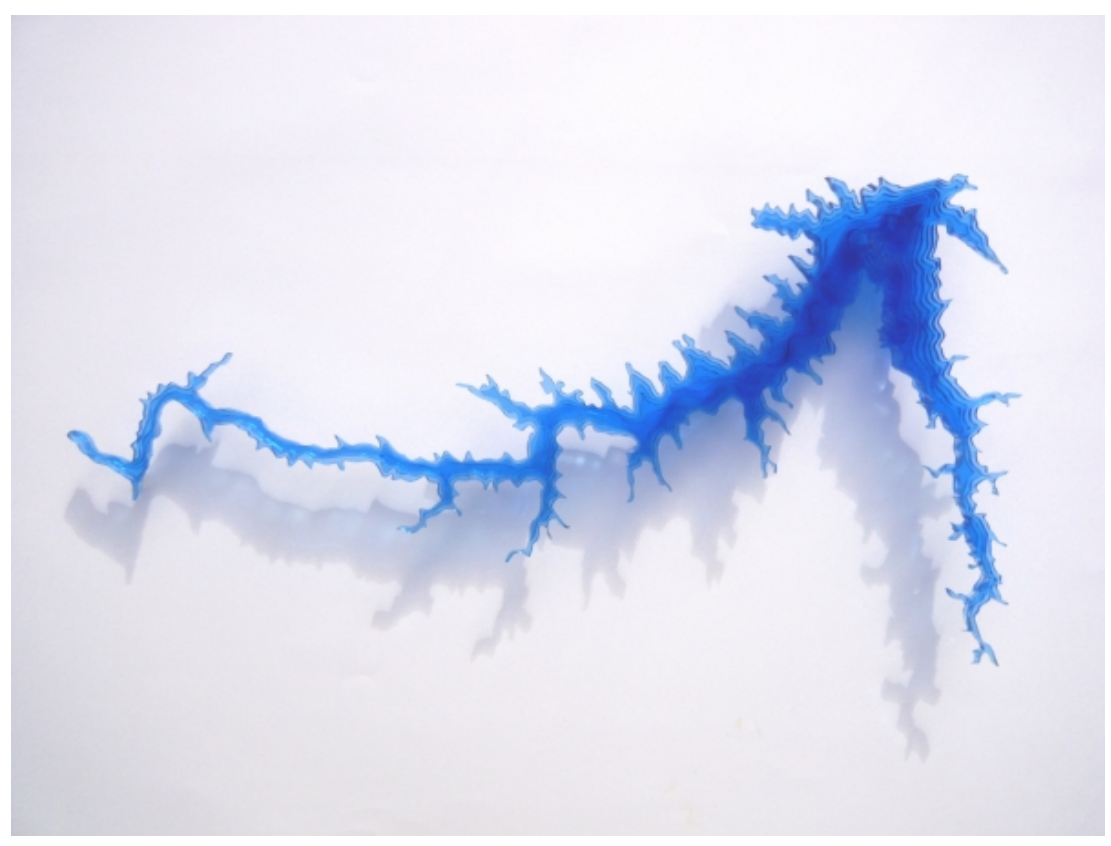


Figure 22: Stephen Cartwright. Sakakawea (2008)

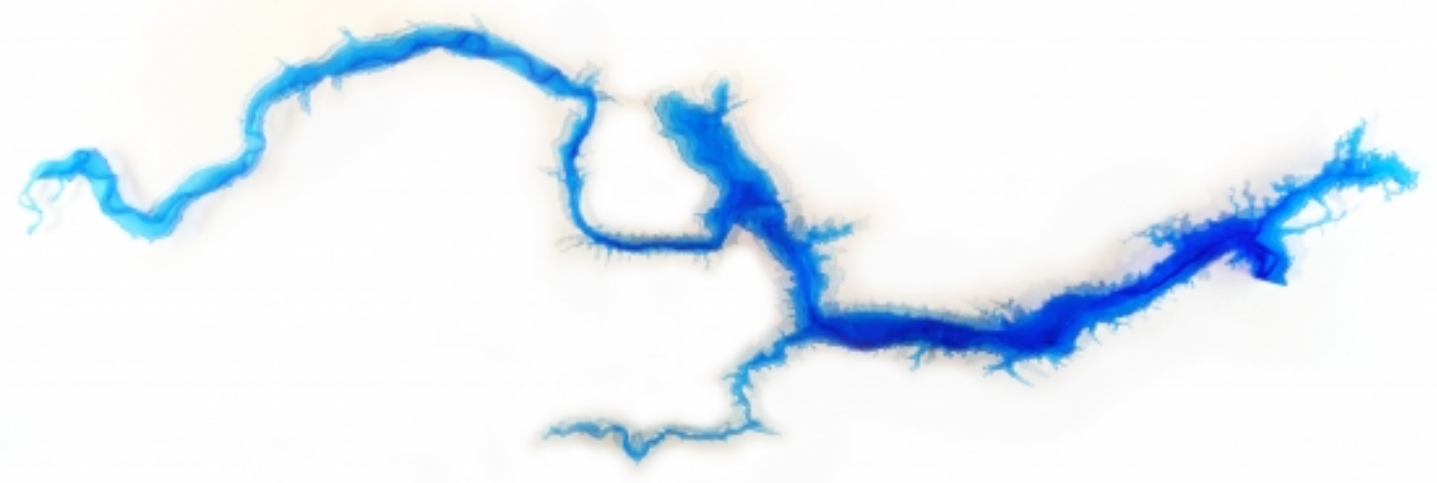

Figure 23: Stephen Cartwright. 2030 (2009)

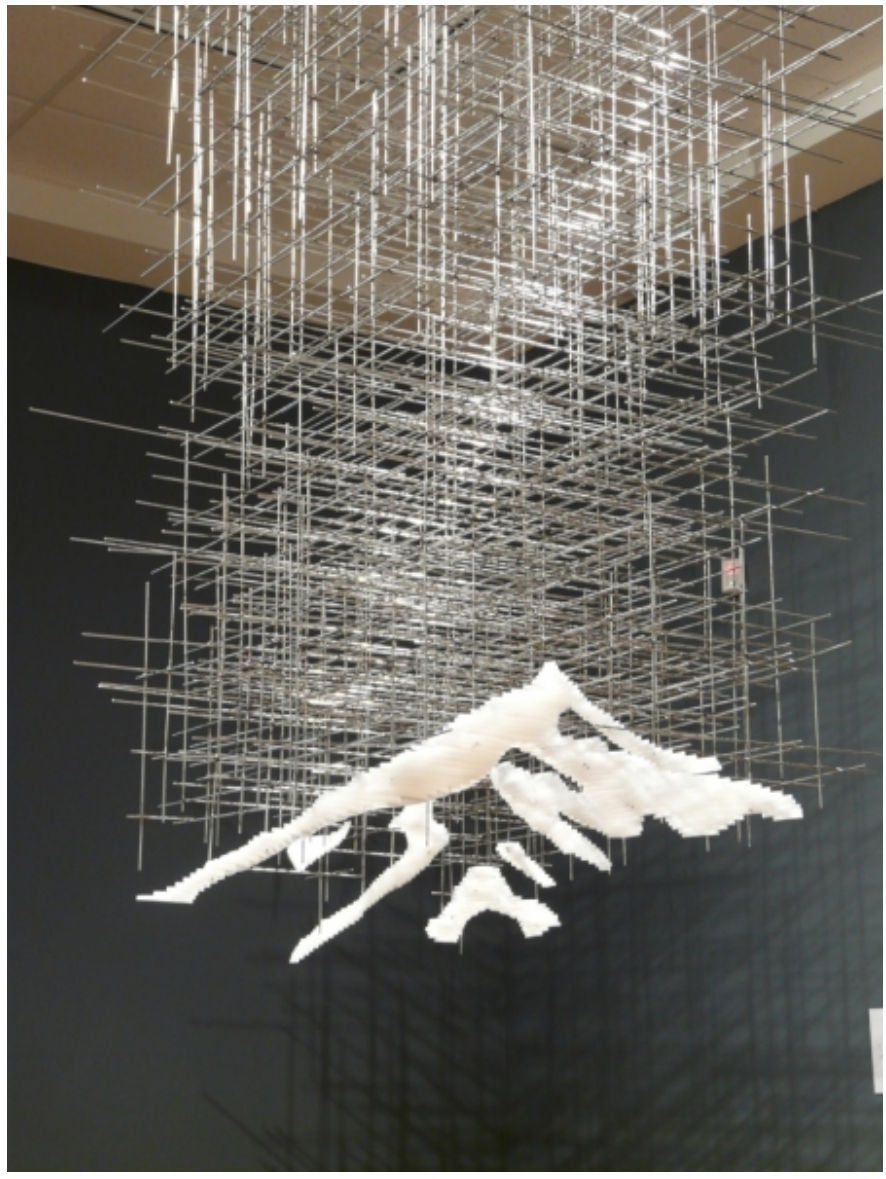


becomes detached and feels little accountability towards the issue. When photographs of an oil spill fill a gallery, it is far easier to blame the men on the ships or the CEO's of companies than it is to acknowledge one's role in the larger equation. Art historian T.J. Demos' explains the phenomenon of dissociation between the event and the viewer in his essay "Art and Ecology" (2009):

One single peril, indeed, is the tendency to accept the flattening of representation's complexity and to surrender intellectual criticality in the face of the real urgency of climate change. The danger here is the public's passive deferral of responsibility to scientific expertise and governmental authority, which makes us vulnerable both to solutions forged by exclusive social and political interests and to the forces of commercial exploitation that would use green rhetoric for the purposes of economic profit. ${ }^{47}$

Cartwright traces his decisions on a quantitative level and understands the relationship that he has to his environment and vice versa. He expresses how the routine of the every man is intertwined in these systems.

The multifariousness of systems is evident when viewing the works of both Cartwright and Katayama. Katayama's work is ecologically aware, and he utilizes his artwork as a catalyst for environmental conversations. Katayama examines the underlying patterns in nature by showcasing shifting perspectives, disruptions, and systemic limitations in ecology. Katayama's work examines the "thing-power" of non-material objects and the

${ }^{47}$ Demos, T. J. "The Politics of Sustainability: Contemporary Art and Ecology." Radical Nature: Art and Architecture for a Changing Planet. 1969-2009, 16-30. London: Barbican Art Gallery, 2009. p. 18. 
entropy of organic and inorganic subjects. ${ }^{48}$ Entropy is a measure of order that occurs in systems. A high entropy system is disordered, where as low entropy systems such as societies and colonies are highly organized. In low entropy systems there is more energy to be transferred into mechanical or systematic work. In Smithson's writings he discusses entropy using the Second Law of Thermodynamics, "which extrapolates the range of entropy by telling us energy is more easily lost than obtained. ${ }^{, 49}$ It is important to make clear that energy lost is not truly destroyed, but rather transferred into another form as explained by the law of conservation. Entropy levels are measured by the amount of order and the availability of energy that can be transferred into work. Systems with more order also have more energy built up that they can transfer. Political theorist Jane Bennett discusses the organization of energy and the structure of non-material objects in her book Vibrant Matter: A Political Ecology of Things (2010) stating that:

Even inorganic matter can 'self-organize': inorganic matter-energy has a wider range of alternatives for the generation of structure than just simple phase transition... In other words, even the humblest forms of matter and energy have the potential for self-organization beyond the relatively simple type involved in the creation of crystals. There are, for instance, those coherent waves called solitons, which form in many different types of materials, ranging from ocean waters (where they are called tsunamis) to lasers. $^{50}$

${ }^{48}$ Bennett, Jane. Vibrant Matter: A Political Ecology of Things. Durham: Duke University Press, 2010. Print. p. 2-6. See, "The idea of thing-power bears a family resemblance to Spinoza's conatus, as well as to what Henry David Thoreau called the Wild or that uncanny presence that met him in the Concord woods and atop Mount Ktaadn [...] Wildness was a not-quite-human force that addled and altered human and other bodies [... ]Thing-Power: the curious ability of inanimate things to animate, to act, to produce effects dramatic and subtle $[\ldots .$.$] thing-power arises from bodies inorganic as well as organic."$ ${ }^{49}$ Smithson, Robert., and Jack D. Flam. "Entropy and the New Monuments," Robert Smithson, the Collected Writings. Berkeley: University of California Press, 1968. Print. The documents of twentieth-century art; Documents of 20th century art. p. 11.

${ }^{50}$ Bennett, Vibrant Matter: A Political Ecology of Things, p. 6. 
Self-organizing structures and the energy that inhabits them are explored in Katayama's oil sharpie drawings that simultaneously resemble substantial events as well as microscopic organisms.

Five separate panels make up the black and gold drawing of E.G.O. (Everybody Grows Old) (2015) (Figure 24). Each cyclical pattern on the canvas is broken and the outermost circle is erased by the edge acting as parentheses to contain the image inside. The panels of pure gold create a frame for the central image. A pattern of repeated circles generated in a ritual-like fashion dance across the canvas in organized chaos. The composition mirrors that of a weather system while the long rectangular panels and the circular lens are reminiscent of an organism on a microscope slide. E.G.O. (Everybody Grows Old) exemplifies the order of these systems and the potential havoc and disruptions that highly organized systems like tornados can inflict on others.

Sustain(ED) (2015) (Figure 25) is a drawing separated into 140 individual panels that accumulate into one cohesive structure when assembled. The drawing is grand yet minuscule, resembling both the universe and a microbe. Each section contains its own unique pattern, which explodes outward from the origin point and contributes to the unity of the entire work. The drawing features intersecting structures created from the repetition of Venn diagrams and the detailed markings create a mandala that condenses the Universe both immense and seemingly insignificant into one all-encompassing structure. Katayama's mandala contrasts with Tibetan sand mandalas created by Buddhist monks that are tediously created over hours using sand and then later destroyed symbolizing the temporality of form. Mandalas are traditionally symmetrical, which creates a unified structure resembling a universe in 
Figure 24: Shohei Katayama. E.G.O. (Everybody Grows Old) (2015)

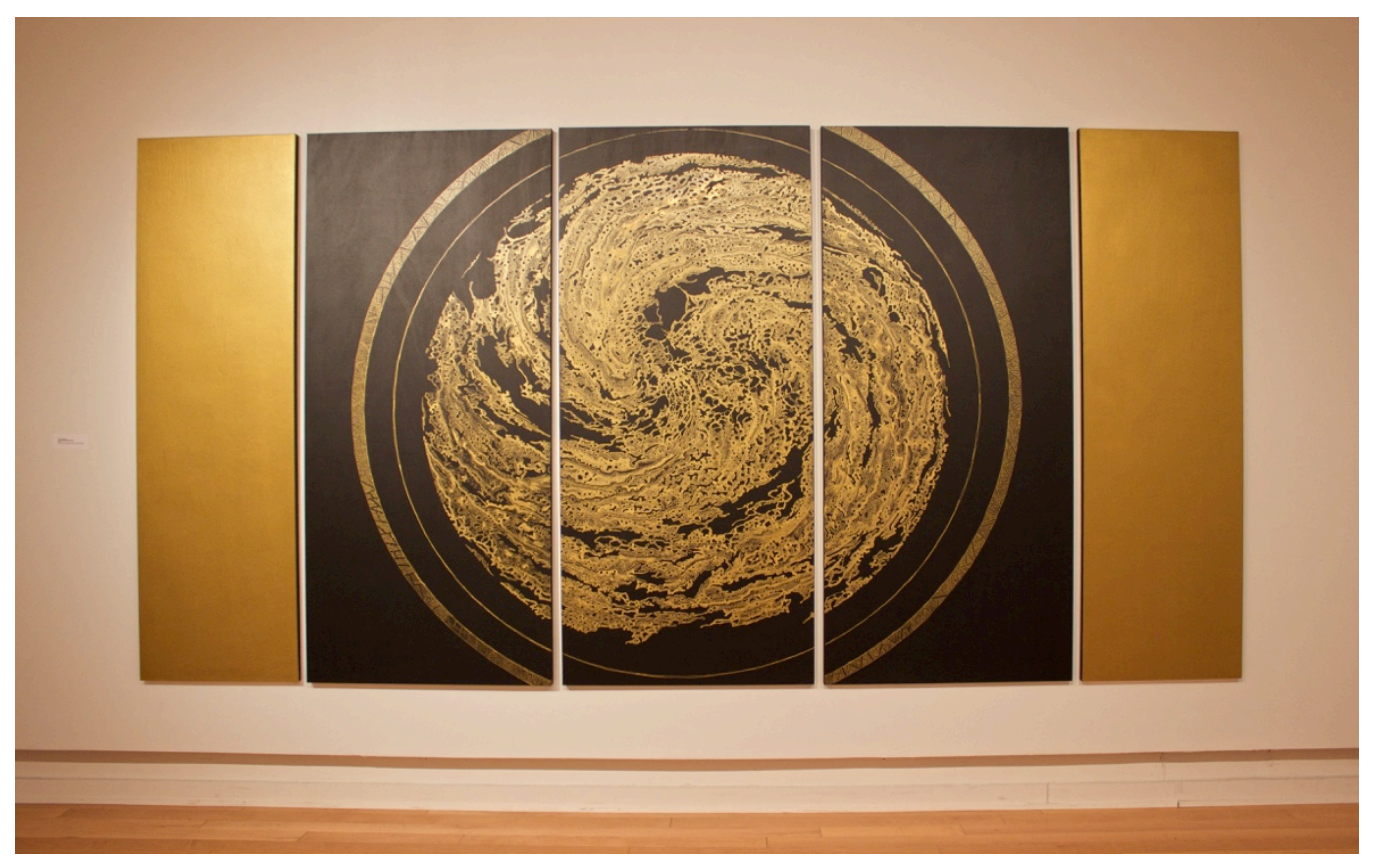

Figure 25: Shohei Katayama. Sustain(ED) (2015)

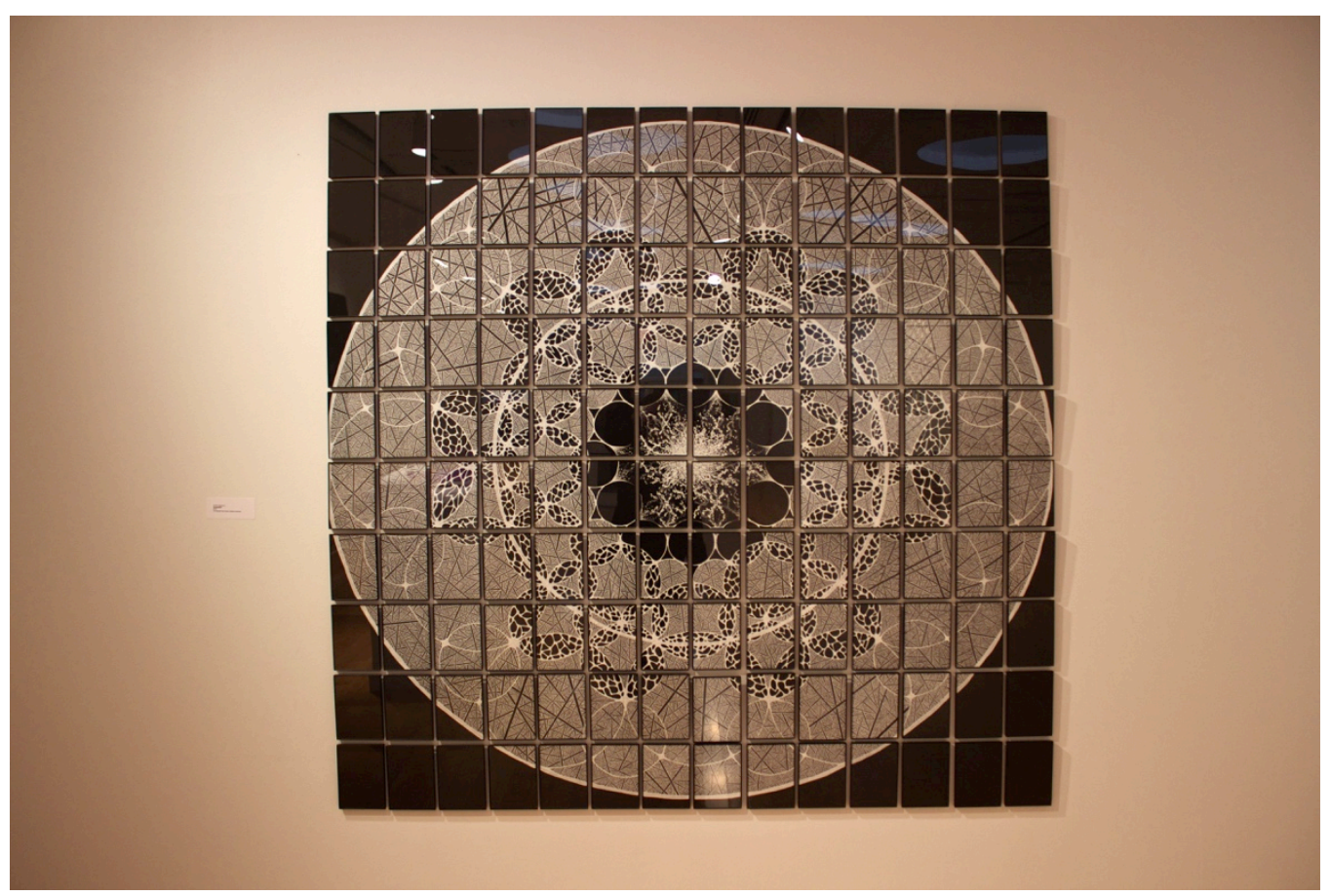


harmony. ${ }^{51}$ Katayama's drawing is less harmonious. It celebrates diversity in more complex systems and takes into account the relative ease with which systems can shift. The patterns in Sustain $(E D)$ are continuous and evolve from an inner axis that extends outward towards the circular edges, much like in Tibetan mandalas where the main source of energy is often found in the center of the image. Sustain $(E D)$ is created utilizing sharpies, a material more permanent and sustainable than sand, yet tedious and ritualistic in the application and installation process. The 140 panels are temporarily hung side by side in a 10 x 14 " grid with small gaps between each pane. Katayama's mandala is created and destroyed with the opening and closing of the exhibition and exists as a cohesive form only in the mind of the viewer. By taking in the artwork as a whole rather than focusing on each individual square, the image becomes one of various joining and intersecting regions that contribute to the entire body of work.

Sustain(ED) relates to political, cultural, and religious ideologies as they take place in mental ecologies and the intersections that overlap. Intersections in religions occur through the repetition of the similar Gods, disciples, holidays, and fundamental teachings. In Abrahamic religions, such as Christianity, Judaism, and Islam, there are obvious parallels to be drawn not only in their monotheistic qualities, but also in the existence of a Holy Book and the rules or commandments to follow. In most religions there is a form of afterlife, the location may take on a different form, but there is a place that the soul goes to when the body dies. Religious holidays also tend to occur during the same months and often correspond to the changing of seasons such as in Paganism and Hinduism, which both celebrate the end of the harvest season between October and November. Each of the 140 black and white panels

${ }^{51}$ Cochran, Tracy. "Mandala Architecture." Omni 16.12.1994. Print. 
has a unique design that corresponds to the overall image of overlapping circles. White lines and cell-like structures are drawn against a black background and make up the overlapping regions in the circles. The circles on the edge of the image are large and grow smaller as they collapse inward. In the work, twelve dark circles resembling an eclipsed sun sit towards the middle of the drawing as a reminder of the arbitrariness of time in connection to the physical universe, rotation of the Earth, and temporality of human experience.

Chained (2016) (Figure 26) utilizes magnetically charged iron flakes in test tubes to reiterate the idea of a cohesive whole as a result of each singular operating element. In this installation, the test tubes are strapped to a wall in a pattern that allows the charge of the flakes to force movement and patterns in the test tubes in close proximity. In Chained, the singular disruption of one test tube creates an event that would force the entire structure to alter. Interruptions in systems create disorder and lead to a chain of events that halt progress and knowledge, and alter the transmission of energy into another path. When these disruptions occur in political systems they might manifest, for example, as modifications in the allocations of funds. Over the past eight years in the United States modifications in funding to both NASA and climate change has resulted in adjustments to economic, political, and environmental systems. As slashes in funding occur progression halts and the funding is placed elsewhere creating new pathways. Over the course of the exhibition, Chained begins to rust, a natural reaction to the oxidation of iron and a reminder of the presence of time in ecology and the importance of the continuous maintenance of sustainable systems.

Much of Katayama's past and present work uses organic materials. Balance (2015) (Figure 27) for example, incorporates iron shavings, cobalt flakes, and magnets to create a temporal work in a continuous state of change. In Katayama's most recent work, he 
Figure 26: Shohei Katayama. Chained (2016)

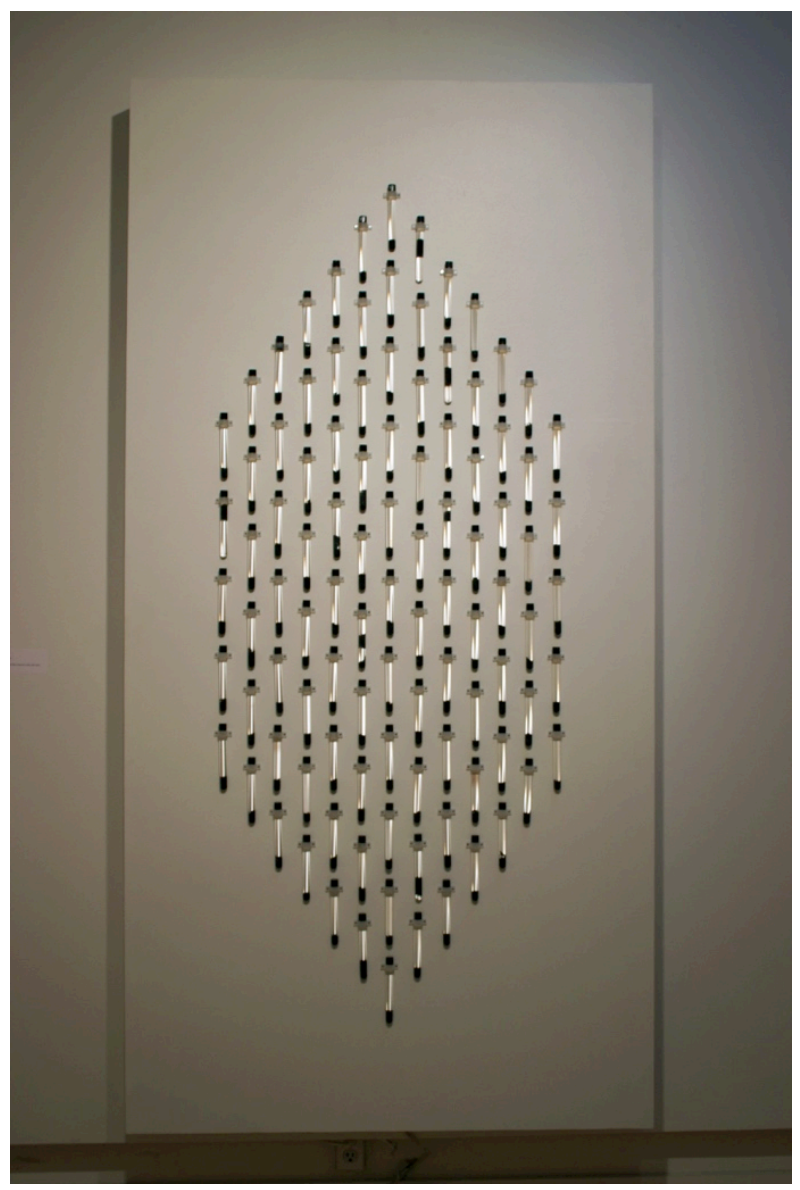

Figure 27: Shohei Katayama. Balance (2015)

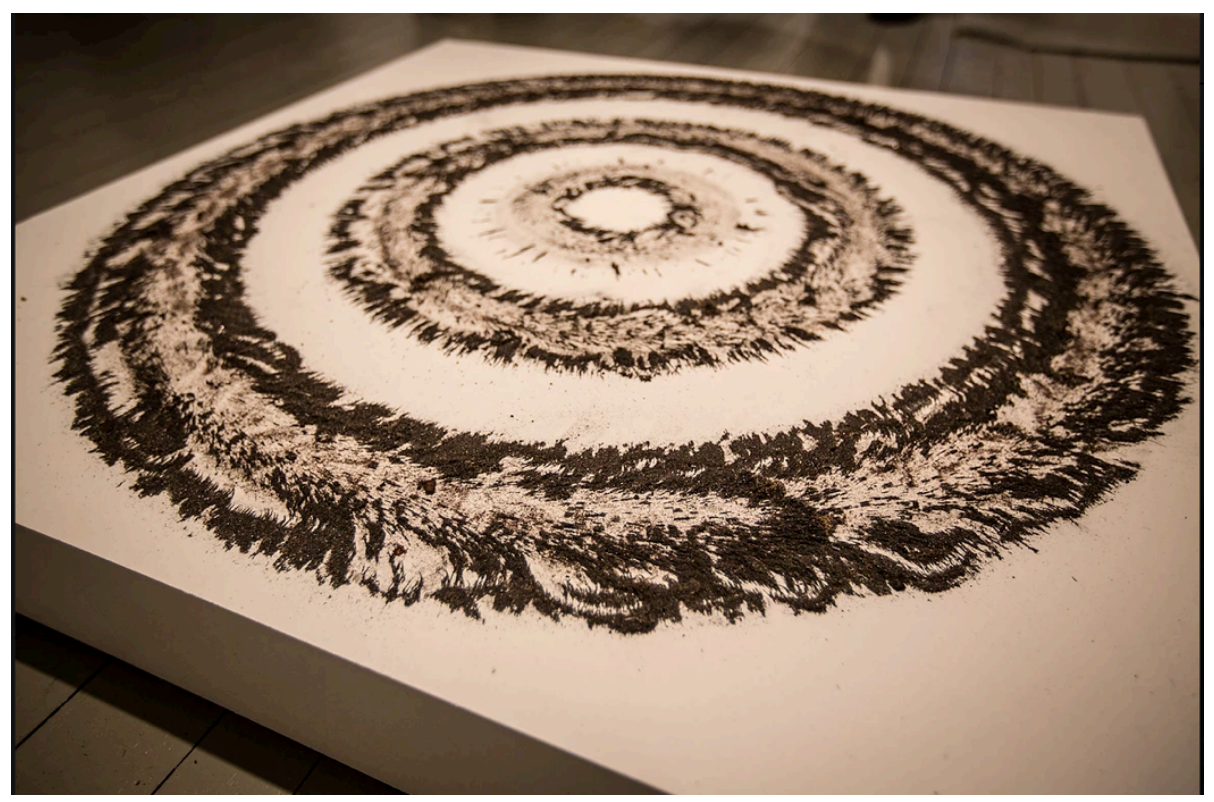


challenges systems through his disruptions and testing of systemic limits. Katayama's work plays with the breakdown of ecologies through the intervention of self-organizing matter. The work establishes an understanding of how various structures function and the unseen relationships between them. Katayama's artworks investigate the impact a single interaction can have on an entire system, causing it to either breakdown or reconfigure. His sculptures reveal the fragility of systems while they also maintain an awareness of the resilience of ecologies. Driving Me Nuts (2016) (Figure 28) inquires about the inorganic and the organic, the intentional and the natural, and the seen and the unseen. In this installation, hidden magnets are placed in acorns, which wobble at a seemingly random frequency. The playful work questions the exchange between organic and inorganic systems. Acorns and magnetic fields are both organic, yet magnets are man-made and the artwork is intentionally deceiving. Katayama investigates the deliberate interruption of systems and the otherwise rigid definition of organic materials by questioning at what point an organism has been dislocated from its organic origin.

Cartwright and Katayama provide viewers with the groundwork to contemplate the interaction between social, mental, and environmental ecologies in Unseen: Visualizing Ecological Systems. These artworks do not offer solutions to ecological issues, instead these artists offer up visualizations of ecologies and question the infinite and continuous intersections of systems. The works take on the role of both the Site and the Non-Site as discussed in Smithson's writing by bringing systems of ecology into the gallery space and investigating where the overlapping regions exist. Cartwright's work exists outside of his sculptures, they are permanent in the section of information that he chooses to graph, but they have a temporality that is dependent on Cartwright's life. Katayama creates analogies 
Figure 28: Shohei Katayama. Driving Me Nuts (2016)

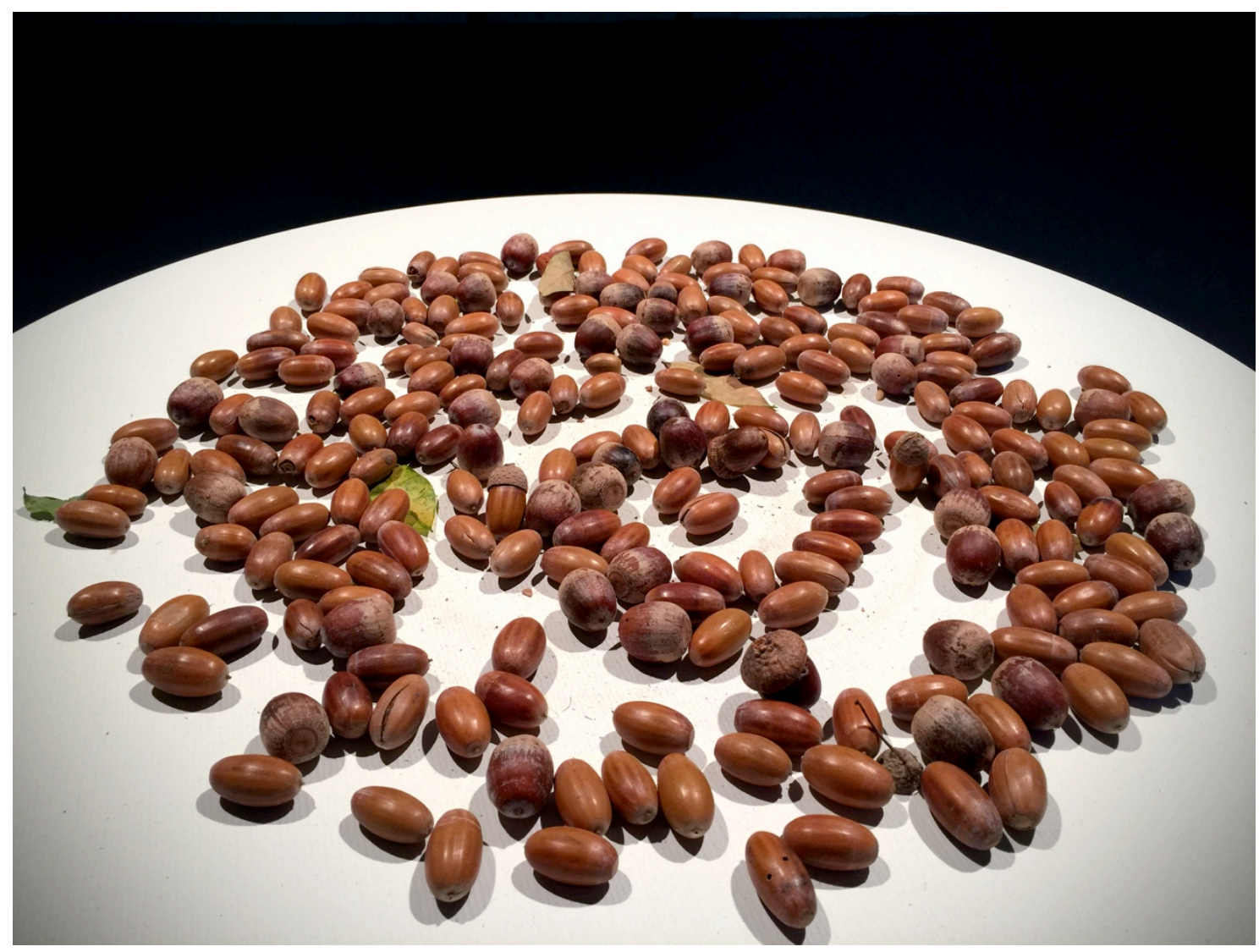


between his visualizations and the ecological systems that are represented. In his sculptures he brings nature into the exhibition space and questions the division between the organic and the inorganic. When he removes the acorns in Driving Me Nuts from their natural environment and alters their form do they become inorganic? This would suggest that when a natural object is brought into a gallery space it becomes less natural. At what point does human disruption in a system create work that is completely dissociated from its original form? Defining the degree of separation between these ecologies and where they intersect is a question investigated in this exhibition. Systematic ecology suggests that all systems are intertwined, that the environment cannot be separated from humans and vice versa. In the overlapping Venn diagram of these two systems where do the works of Cartwright, Katayama, and Smithson fall? If the assumption is that Smithson's Site works hold more energy and significance because they are a temporal part of nature, the works of Cartwright and Katayama then must exist somewhere on a spectrum that distinguishes the breaks between organic and inorganic, Site and Non Site, and temporality versus permanence. 


\section{CONCLUSION}

\section{SEPARATION BETWEEN REPRESENTATION AND FORM}

Throughout the history of art, artists have explored the relationship between man and nature. However, it is rare that artists acknowledge the complexity of ecological systems outside of the environmental realm. This project began as an investigation into the visualizations of ecological systems and evolved into an examination of limits and boundaries of ecology and transversal approaches in the arts. As boundaries are tested, the artworks in this project begin to pick apart the foundations of art, culture, time, space, perspective, and language. When systems are ignored in favor of an eco-aesthetic, the artworks often move into the realm of the fictional and feature imaginary landscapes or closed unrealistic systems. Artworks that emphasize the boundaries of systems reveal core truths about the interactions between various regions. Removing man's role in ecological systems denies the interactions that take place in the social, mental, and environmental ecologies. Man exists in all spheres of interaction and does not take part in a closed system. The human-system involvement discussed in this project gives work contextual meaning. Language, materiality, place, and time are established through the communication and interconnectivity between regions of ecological systems.

By testing the limits of systems and investigating the overlapping regions through an interdisciplinary perspective, the artwork becomes a figure of speech signifying a range of signs without possessing the constricting binary limits of an origin point. In the work of 
Smithson, his sculptures do not point to a single signifier rather he allows the sculpture to create a form of visual vocabulary. The soil used by Smithson does not simply represent one location; instead it encompasses the entire history (past, present, and future). The fragmentation and decentralization that occurs in non-sites creates a text (or in Cartwright's case a graph) that can be read in a linear perspective, but also dissected into a network of nodes. The non-sites in this project transcribe information using materials and data to create contextual meaning. For the viewer, the materials transform from a graph or a pile of rubble into a network of signifiers in the ecological systems. By bringing systems of ecology into the gallery space and investigating the overlapping regions, artworks take on the role of the Site and the Non-Site as discussed in Smithson's writings. The artworks test the boundaries of disruption and examine the length and mode in which an object can be removed from its original form before losing contextual and linguistic meaning. 


\section{REFERENCES}

Bell, Michelle L. et al. "A Retrospective Assessment of Mortality from the London Smog Episode of 1952: The Role of Influenza and Pollution." Environmental Health Perspectives, vol. 112, no. 1, 2004, Web. Retrieved 20 Dec. 2016. www.jstor.org/stable/3435787.

Bennett, Jane. Vibrant Matter: A Political Ecology of Things. Durham: Duke University Press, 2010. Print.

Benthall, Jonathan. Science and Technology in Art Today. New York: Praeger, 1972. Print.

Bijvoet, Marga. Art As Inquiry: Toward New Collaborations between Art, Science, and Technology. New York: Peter Lang, 1997. Print. American University Studies. Series XX, Fine arts, v. 32.

Black J. "Intussusception and the Great Smog of London, December 1952." Archives of Disease in Childhood 88.12 2003. Print.

Cochran, Tracy. "Mandala Architecture." Omni 16.12.1994. Print.

Demos, T.J. Decolonizing Nature: Contemporary Art and the Politics of Ecology. Sternberg Press, 2016. Print.

Demos, T. J. "The Politics of Sustainability: Contemporary Art and Ecology.” Radical Nature: Art and Architecture for a Changing Planet. 1969-2009, 16-30. London: Barbican Art Gallery, 2009.

Derrida, Jacques. Writing and Difference. Chicago: University of Chicago Press, 1978. Print.

"Earth." Interview by Thomas W. Leavitt. Cornell University. Symposium at White Museum, Ithaca, New York, 1969. Television. Transcript.

Fer, Briony. "Judd's Specific Objects," On Abstract Art. New Haven, CT: Yale University Press, 1997, Print.

Foucault, Michel. The Archaeology of Knowledge. Vintage, 1972. Print.

Guattari, Félix. The Three Ecologies. London: Continuum, Continuum impacts. 2008. Print. 
Gutierrez, Melody. "California becomes first state to ban plastic bags." San Francisco Chronicle. 30 Sept. 2014. Web. Retrieved 11 Dec. 2016. http://www.sfgate.com/politics/article/California-becomes-first-state-to-ban-plasticbags-5791041.php

"In the Wake: Japanese Photographers Respond to 3/11." Henry Lois Foster Gallery. 2015. Web. Retrieved 20 Dec. 2016. http://www.mfa.org/exhibitions/in-the-wake

Krauss, Rosalind. "Sculpture in the Expanded Field." October, Vol 8. MIT Press. Spring 1979. Print.

Kurt, Hildegard. "Aesthetics of Sustainability," Ecological Aesthetics. Art in Environmental Design, Boston: Birkhauser, 2004. Print.

Lippard, Lucy R., and Chandler, John. “The Dematerialization of Art (1967-68)," Art International, February, 1968. Web. Retrieved 14 Mar. 2017.

Lofton, Kara. "It's Not Just Lake Erie. The Ohio River Has A Major Algae Problem, Too." WESA Pittsburgh's NPR Newstation. NPR, 18 Nov. 2016. Web. Retrieved 20 Nov. 2016. <http://wesa.fm/>.

Owens, Craig. "Earthwords." October, vol. 10, 1979, Web. Retrieved 09 Mar. 2017. www.jstor.org/stable/778632.

Saussure, Ferdinand de. "General Principles: Nature of the Linguistic Sign." Course in General Linguistics. (n.p.) 1916. Print.

Shibata, Seiji, Naoto Suzuki. "Effects of an Indoor Plant on Creative Task Performance and Mood." Scandinavian Journal of Psychology 45.5. 2004. Print.

Smithson, Robert., and Jack D. Flam. "A Sedimentation of the Mind: Earth Projects.” Robert Smithson, the Collected Writings. Berkeley: University of California Press, 1968. Print. The documents of twentieth-century art; Documents of 20th century art.

Smithson, Robert., and Jack D. Flam. "Entropy and the New Monuments," Robert Smithson, the Collected Writings. Berkeley: University of California Press, 1968. Print. The documents of twentieth-century art; Documents of 20th century art.

Tomasello, Michael. “A Focus on Infrastructure.” Origins of Human Communication. MIT Press Cambridge: Massachusetts. 2010. Print.

“Zika outbreak: US Congress blocks Zika funding bill.” BBC News. 7 Sept. 2016. Web. Retrieved 11 Dec. 2016. http://www.bbc.com/news/world-us-canada-37293329 


\section{APPENDICES}

Table 1: Budget Unseen: Visualizing Ecological Systems

\begin{tabular}{|l|l|}
\hline Item & Cost \\
\hline Spread for opening & $\$ 300$ \\
\hline Travel (gas) Steve & $\$ 42$ \\
\hline Rooms (1 night x 2 people) & $\$ 240$ \\
\hline Catalogue (28 copies) & $\$ 308$ \\
\hline Dinner after opening & $\$ 130$ \\
\hline Postcards & $\$ 170$ \\
\hline Email blast & $\$ 40$ \\
\hline Wall text and vinyl & $\$ 128$ \\
\hline $\begin{array}{l}\text { Jessica gas for Steve's } \\
\text { artworks }\end{array}$ & $\$ 140$ \\
\hline Total & $\$ 1498$ \\
\hline
\end{tabular}


Table 2: Check-List: Unseen: Visualizing Ecological Systems

\begin{tabular}{|c|c|c|c|c|}
\hline Artist & Title & Year & Material & Dimensions \\
\hline $\begin{array}{l}\text { Stephen } \\
\text { Cartwright }\end{array}$ & $\begin{array}{l}\text { "Floating Data" } \\
\text { (Human Powered Outdoor Activity } \\
\text { and Temperature 2014-2015) }\end{array}$ & 2016 & Acrylic, dyed resin & $\begin{array}{l}2 \times 22 \times \\
12.5 "\end{array}$ \\
\hline $\begin{array}{l}\text { Stephen } \\
\text { Cartwright }\end{array}$ & $\begin{array}{l}\text { "Floating Data" } \\
\text { (Human Powered Outdoor Activity } \\
\text { and Driving Mileage 2014-2015) }\end{array}$ & 2016 & Acrylic, dyed resin & $2 \times 32 \times 16 "$ \\
\hline $\begin{array}{l}\text { Stephen } \\
\text { Cartwright }\end{array}$ & $\begin{array}{l}\text { "Floating Data" } \\
\text { (Human Powered Outdoor Activity } \\
\text { 2014-2015) }\end{array}$ & 2016 & Acrylic, dyed resin & $12 \times 12 \times 6.5 "$ \\
\hline $\begin{array}{l}\text { Stephen } \\
\text { Cartwright }\end{array}$ & Chromatic Data Oscillator & 2016 & $\begin{array}{l}\text { LEDs, aluminum, } \\
\text { servos, mixed media }\end{array}$ & $96 \times 30 \times 17 ”$ \\
\hline $\begin{array}{l}\text { Stephen } \\
\text { Cartwright }\end{array}$ & $\begin{array}{l}\text { "Floating Data" } \\
\text { (Human Powered Outdoor Activity } \\
\text { 2011-2014) }\end{array}$ & 2015 & Acrylic, dyed resin & $7 \times 5 \times 3 "$ \\
\hline $\begin{array}{l}\text { Stephen } \\
\text { Cartwright }\end{array}$ & $\begin{array}{l}\text { "Floating Data" } \\
\text { (Driving 2011-2014) }\end{array}$ & 2015 & Acrylic, dyed resin & $7 \times 5 \times 3 "$ \\
\hline $\begin{array}{l}\text { Stephen } \\
\text { Cartwright }\end{array}$ & $\begin{array}{l}\text { "Floating Data" } \\
\text { (Precipitation 2011-2014) }\end{array}$ & 2015 & Acrylic, dyed resin & $7 \times 5 \times 3 "$ \\
\hline $\begin{array}{l}\text { Stephen } \\
\text { Cartwright }\end{array}$ & $\begin{array}{l}\text { Data Topography } \\
\text { (Bedtime 2012-2014) }\end{array}$ & 2015 & Hot cast glass & $\begin{array}{l}5.5 \times 5.5 \times \\
2.5 ”\end{array}$ \\
\hline $\begin{array}{l}\text { Stephen } \\
\text { Cartwright }\end{array}$ & $\begin{array}{l}\text { Data Topography } \\
\text { Data Casts: Wind Map }\end{array}$ & 2014 & Kiln cast glass & $7 \times 10 \times 3 "$ \\
\hline $\begin{array}{l}\text { Shohei } \\
\text { Katayama }\end{array}$ & Driving Me Nuts & 2016 & $\begin{array}{l}\text { Acorns, water, } \\
\text { magnets, motion- } \\
\text { sensor. }\end{array}$ & $16 \times 30 \times 30 "$ \\
\hline $\begin{array}{l}\text { Shohei } \\
\text { Katayama }\end{array}$ & Chained & 2016 & $\begin{array}{l}\text { Glass, Iron-oxide } \\
\text { flakes, mineral oil, } \\
\text { water, gear motor }\end{array}$ & $96 \times 48 \times 7 "$ \\
\hline $\begin{array}{l}\text { Shohei } \\
\text { Katayama }\end{array}$ & Splash & 2016 & $\begin{array}{l}\text { Hand drawn oil-based } \\
\text { white sharpie on latex }\end{array}$ & $80 \times 79 "$ \\
\hline $\begin{array}{l}\text { Shohei } \\
\text { Katayama }\end{array}$ & Tension & 2015 & $\begin{array}{l}\text { Glass, neodymium } \\
\text { magnets, HMA, } \\
\text { epoxy, monofilament } \\
\text { string }\end{array}$ & 3.5" diameter \\
\hline $\begin{array}{l}\text { Shohei } \\
\text { Katayama }\end{array}$ & $\operatorname{Sustain}(E D)$ & 2015 & $\begin{array}{l}140 \text { framed hand } \\
\text { drawn sharpie } \\
\text { drawings }\end{array}$ & $76.5 \times 78.5 "$ \\
\hline $\begin{array}{l}\text { Shohei } \\
\text { Katayama }\end{array}$ & E.G.O. (Everybody Grows Old) & 2015 & $\begin{array}{l}\text { Hand drawn oil-based } \\
\text { gold sharpie on latex, } \\
\text { gold leaf }\end{array}$ & $80 \times 164 "$ \\
\hline
\end{tabular}


Figure 29-31: Floor plan Unseen: Visualizing Ecological Systems

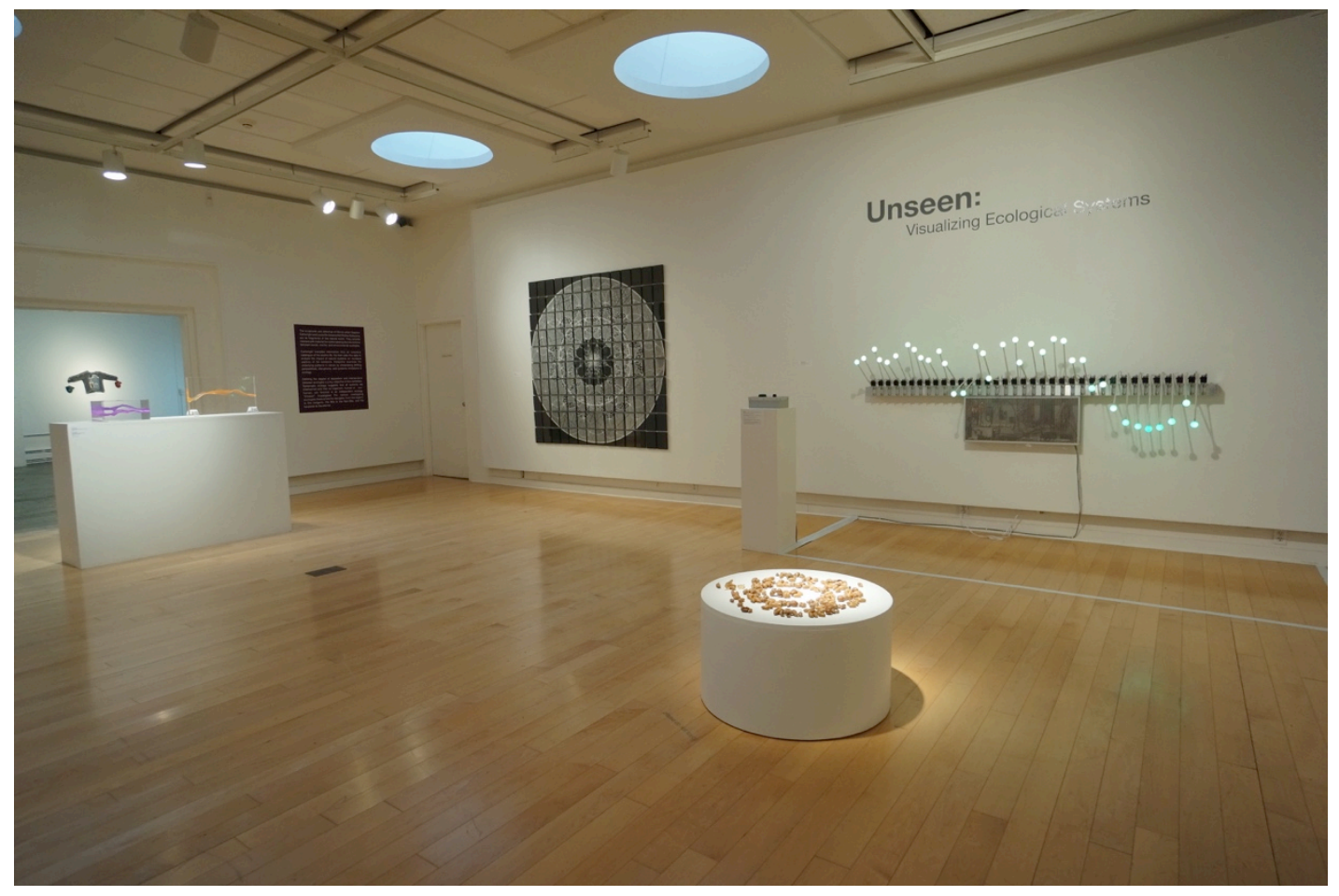

Figure 30:

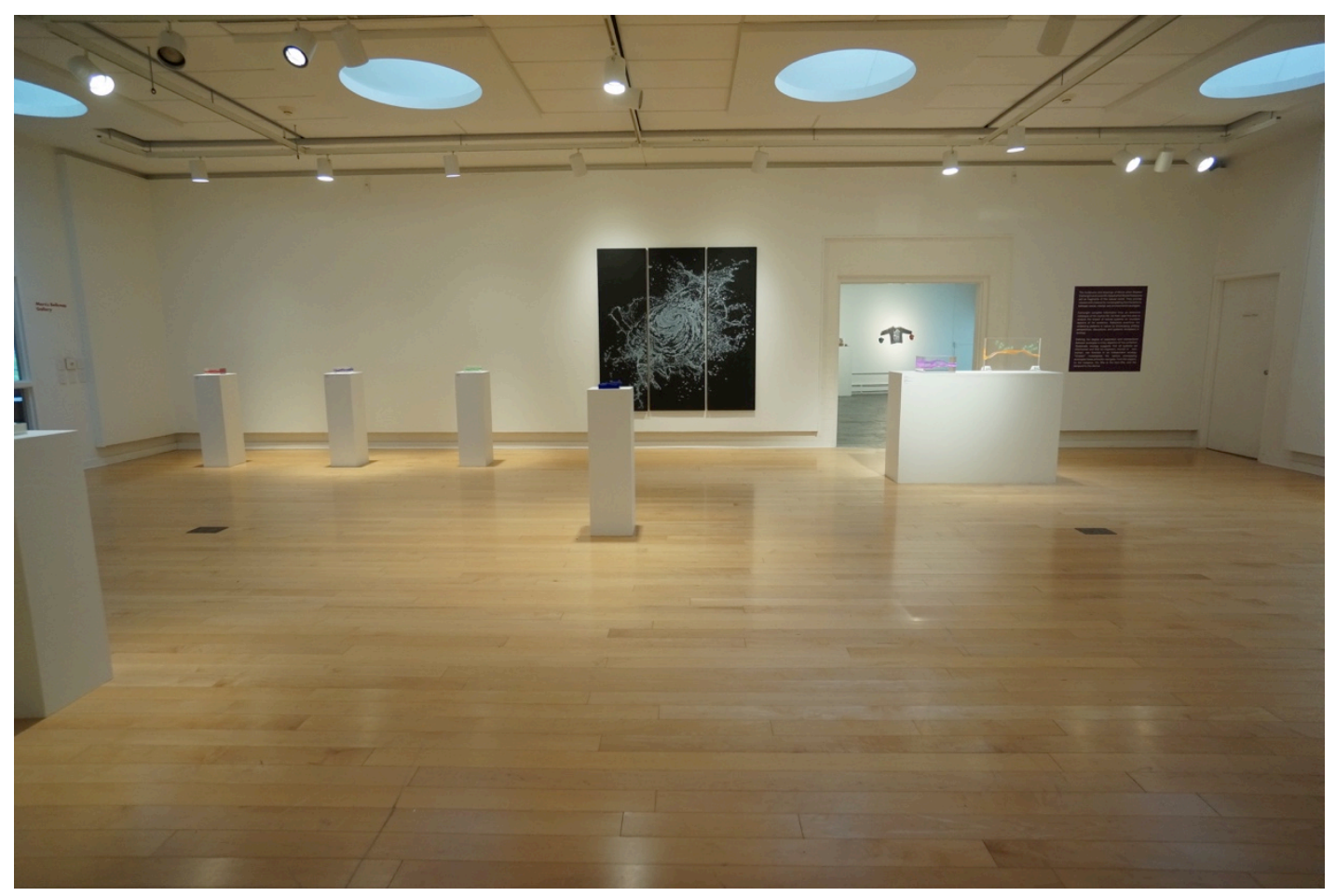


Figure 31:

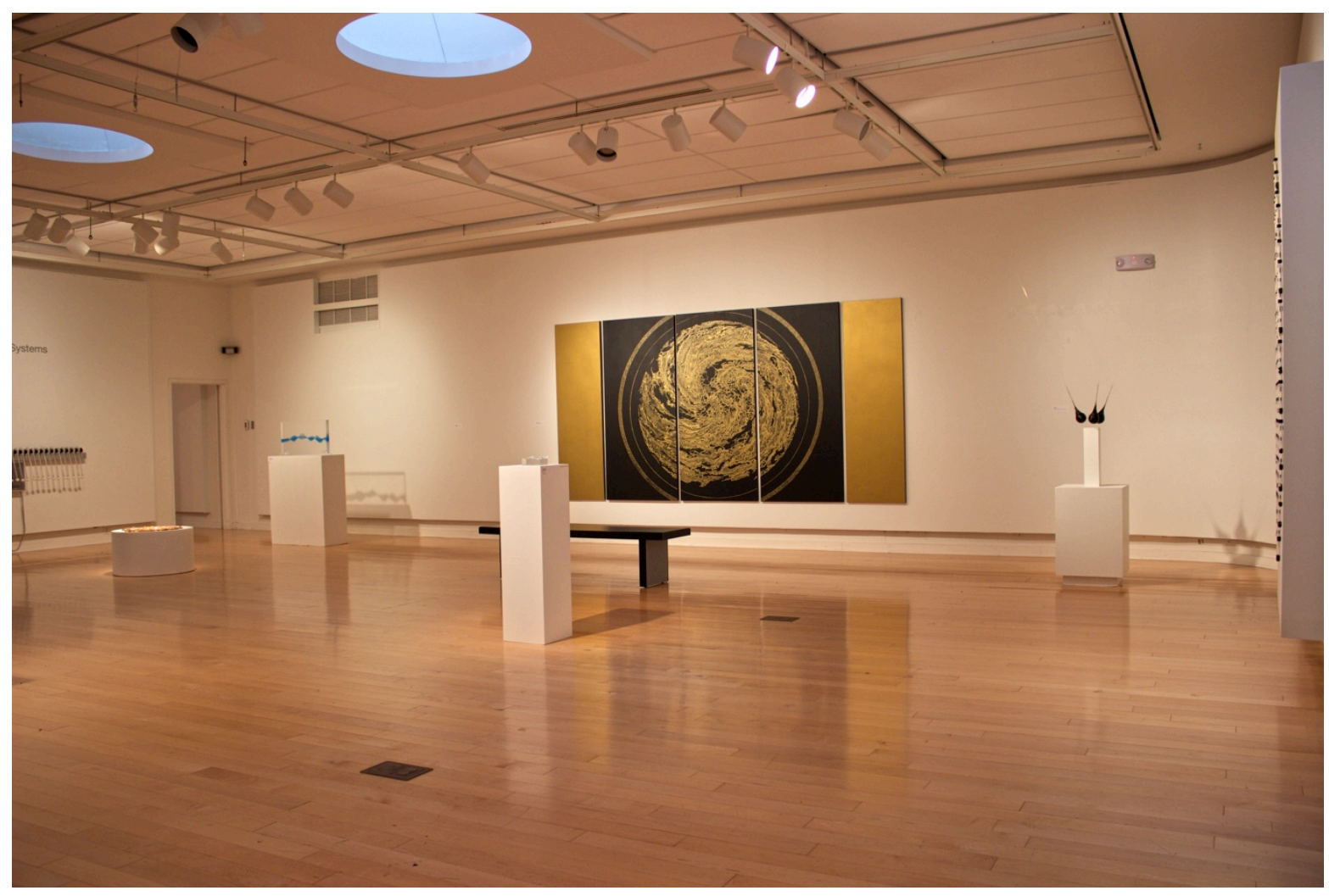


Figure 32-33: Email blast: Unseen: Visualizing Ecological Systems Reception: Jan 12, 2017 • 6:00 pm - 8:00 pm | map

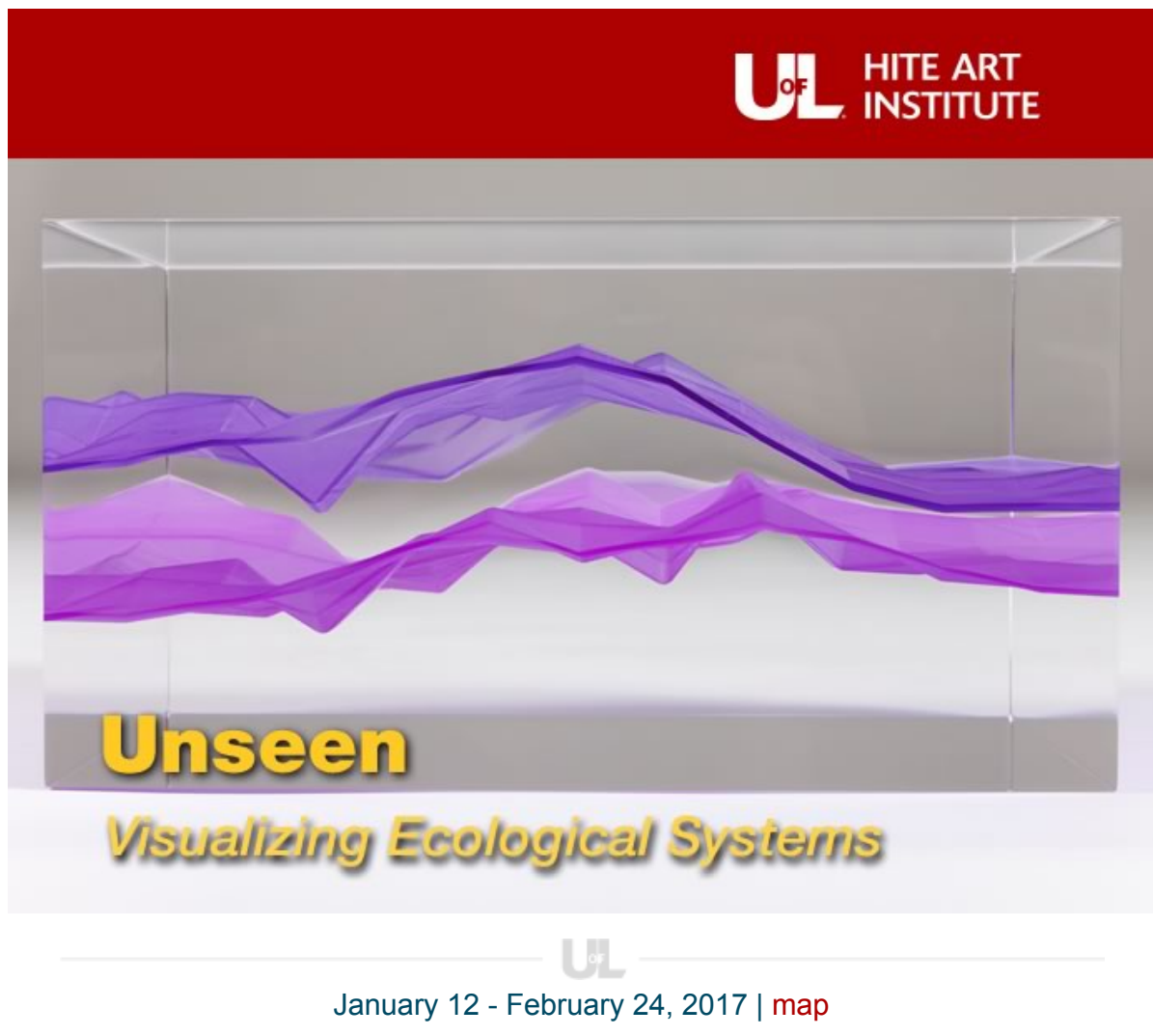

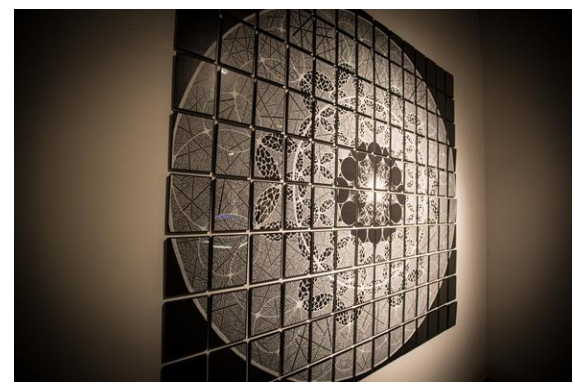

Unseen: Visualizing Ecological Systems
The University of Louisville Hite Art Institute is pleased to present "Unseen: Visualizing Ecological Systems," an exhibition curated by critical and curatorial studies master's candidate Madison Sevilla. "Unseen" features sculptures and drawings by Stephen Cartwright and Shohei Katayama that explore the intersections between art and ecology.

Cartwright's data visualization

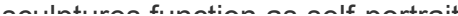




\section{Figure 33:}

$3 / 30 / 2017$

\author{
On view: \\ January 12 - February 24, 2017 \\ Reception: \\ January 12, 2016 • 6:00 - 8:00 pm \\ Hite Art Institute \\ Schneider Hall Galleries \\ Louisville, KY 40292 \\ Gallery Hours \\ Mon - Fri: 9am - 4:30pm
}

Fine Art - University of Louisville

scuiplures inIlctivil as sell-purtadis

created through detailed

documentation of his life and

routines. The sculptures contrast

graphed data about his

geographical location (such as

wind patterns, temperature, and

precipitation) against his activity

levels, forms of activity, and mental

health. Katayama's work examines

the underlying patterns and forces

of nature by showcasing unseen

relationships in ecology. Through

his work, Katayama demonstrates

the entanglements that are present

between such systems and

illustrates the disruptions that can

occur when individual components are manipulated.

"Unseen: Visualizing Ecological

Systems" provides viewers with the groundwork to contemplate the impact on and interactions between the various systems that surround us. Cartwright and

Katayama offer up visualizations of the infinite and continuous ecologies that constitute our routines.

\section{$12 \times 12 \times 6.5$ in. Photo coures of Will 100}

Left: Shohei Katagama, Sustain (ED), 2015, 140 framed hand drawn Sharpie drawings, $76.5 \times$ ×8.5 it
More Fine Arts News

Forward

$\underline{\text { Unsubscribe }}$
Fine Arts Facebook

Contact Us

UofL Hite Art Institute

(502) 8526794

louisville.edu/art/
Fine Arts website

LIL HITEART
(C) Copyright 2016-2020 University of Louisville Fine Arts.

Copy, reuse or editing of this content is strictly prohibited without prior written approval. 
Figure 34: Press: Unseen Visualizing Ecological Systems

Triplett, Jo Anne, "Staff Pick: 'Unseen-Visualizing Ecological Systems." LEO Weekly. http://www.leoweekly.com/event/unseen-visualizing-ecological-systems/

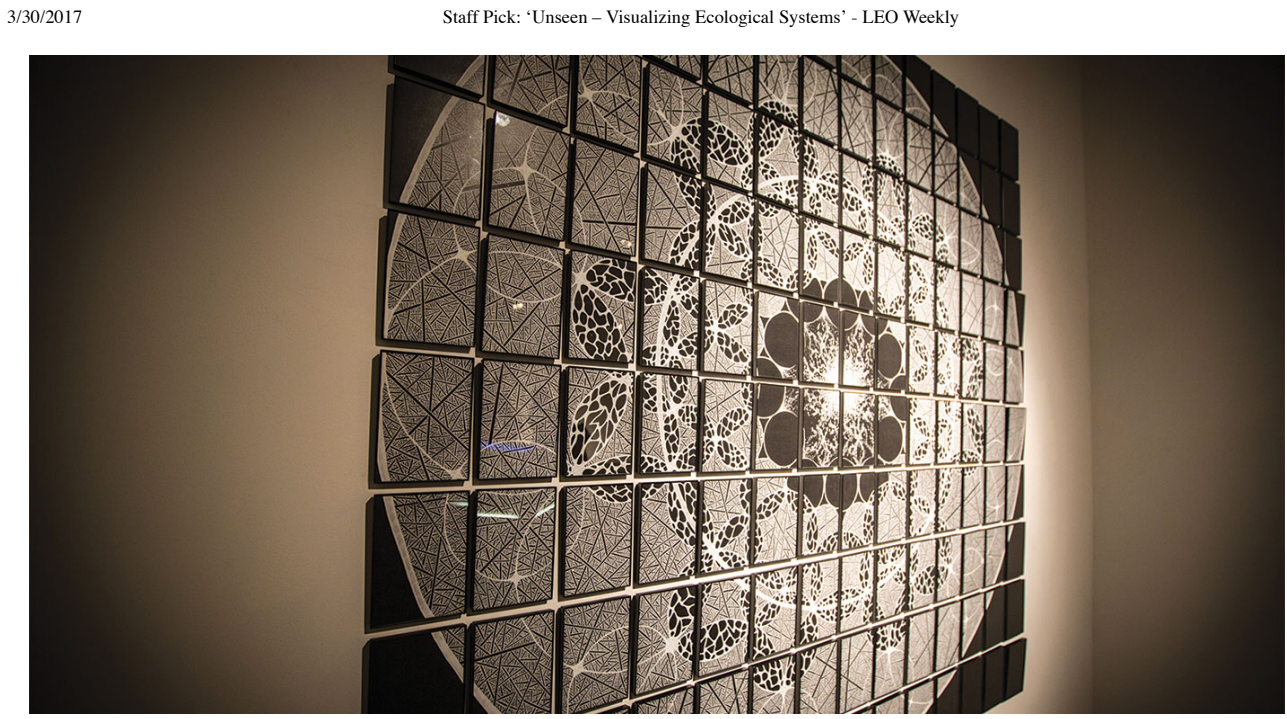

(http://www.leoweekly.com/event/unseen-visualizing-ecological-systems/)

"Sustain(ED)" by Shohei Katayama

STAFFPICKS (HTTP://WWW.LEOWEEKLY.COM/CATEGORY/STAFFPICKS/)

Staff Pick: 'Unseen - Visualizing Ecological Systems'

Feb 082017

BY JO ANNE TRIPLETT (MAILTO:JTRIPLETTART@YAHOO.COM)

Stephen Cartwright and Shohei Katayama's exhibition "Unseen: Visualizing Ecological Systems" is about the biology of organisms and their environment. But instead of scientific charts and maps, they created sculptures and drawings to explain ecology (this is what I needed in high school). The show is curated by critical and curatorial studies master's candidate Madison Sevilla. "'Unseen: Visualizing Ecological Systems' provides viewers with the groundwork to contemplate the impact on and interactions between the various systems that surround us," said Sevilla. "Cartwright and Katayama offer up visualizations of the infinite and continuous ecologies that constitute our routines."

THROUGH FEB. 24

Schneider Hall Galleries

Mondays-Fridays 9 a.m.-4:30 p.m. | Free

Hite Art Institute, UofL

http://louisville.edu/art (http://louisville.edu/art)

Published under Staffpicks (http://www.leoweekly.com/category/staffpicks/) 
Figure 35: Press: Unseen Visualizing Ecological Systems

Kramer, Elizabeth. "Ecology as seen through an artists' eyes." Courier-Journal. 5 Jan. 2017. http://www.courier-journal.com/story/entertainment/arts/visual/2017/01/05/ecology-seenthrough-artists-eyes/95919188/

\section{Ecology as seen through an artists' eyes}

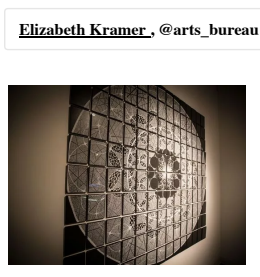

(Photo: Frank.Bui. Courtesy University of Louisville.)

Published 7:02 a.m. ET Jan. 5, 2017 | Updated 3:17 p.m. ET Jan. 6, 2017

For years, the work of artists Stephen Cartwright, of Illinois, and Shohei Katayama, of Louisville, has delved into ideas taken from nature's processes and the state of ecology.

Now, their work is part of the exhibit, "Unseen: Visualizing Ecological Systems," at the University of Louisville curated by Madison Sevilla, a Master of Arts degree in critical and curatorial studies.

- READ MORE: African-American art show has significant history (http://http://www.courierjournal.com/story/entertainment/arts/visual/2017/01/06/african-american-art-show-has-significanthistory/96110916/)

- READ MORE: Plein air featured in "Brush with Nature" (/story/entertainment/arts/visual/2017/01/05/plein-air-featured-brushnature/95919190/)

Cartwright's work launches into ecological examinations by using data detailing the artist's own life to create drawings and sculptures using various materials, including glass and acrylic resins. His work contrasts his personal data with other information such as wind patterns, temperature and precipitation.

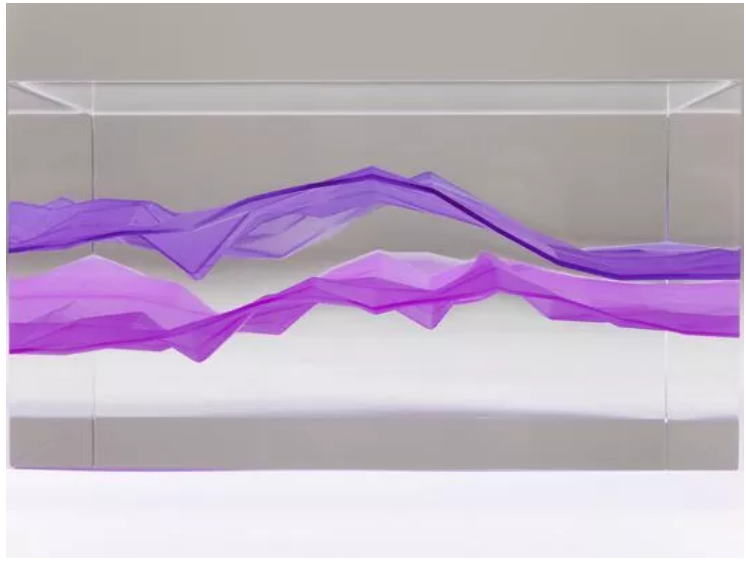

"Human Powered Outdoor Activity" by Stephen Cartwright is part of the exhibit "Unseen: Visualizing Ecological Systems" at the University of Louisville. (Photo: Courtesy University of Louisville.)

Katayama, whose work has been shown at Asia Institute Crane House and PYRO Gallery, uses an array of materials, including paint and ink, as well as magnets and iron flakes to give a kind of bird's-eye view into nature's patterns, such as natural disasters and pollution.

Cartwright, an associate professor and associate director for the School of Art and Design at the University of Illinois in Urbana-Champaign, III., has exhibited around the country.

Katayama, a Japanese-American artist, has exhibited mostly in the Eastern United States and is now a Master of Fine Arts candidate at Carnegie Mellon University in Pittsburgh.

WHEN: Thursday, Jan. 12, through Feb. 24. 23. Opening reception, 6-8 p.m., Thursday, Jan. 12.

WHERE: University of Louisville, Schneider Hall Galleries. Hours are 9 a.m.-4:30 p.m., Monday through Friday; 1-5 p.m., Saturday and Sunday. 
Figure 36-37: Press: Unseen Visualizing Ecological Systems

King, Nikki. "Hite Art Institute offers exhibition that examines art and ecology." UofL News. Press Release. 21 Dec. 2016. http://uoflnews.com/releases/hite-art-institute-offers-exhibitionthat-examines-art-and-ecology/

3/30/2017 Hite Art Institute offers exhibition that examines art and ecology I UofL News

$\equiv$

Hite Art Institute offers exhibition that examines art and ecology

By Niki King - DECEMBER 21, 2016

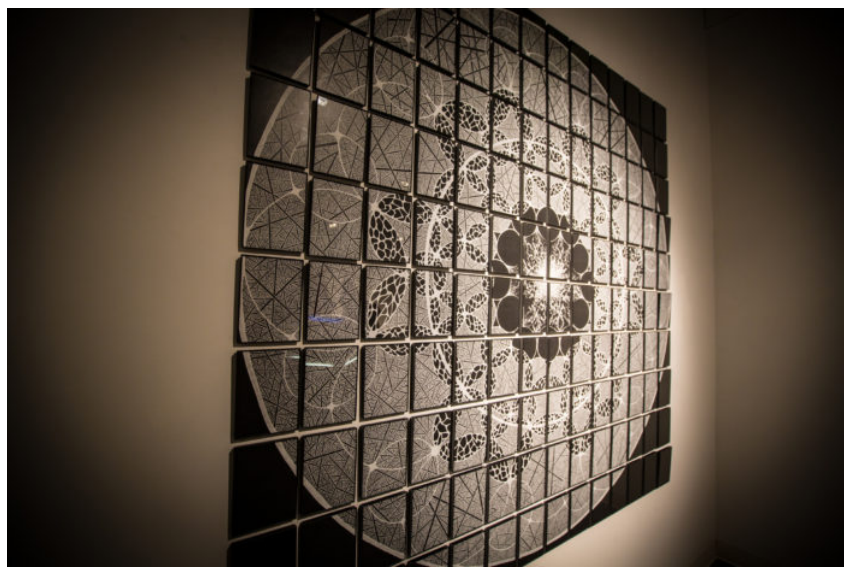

LOUISVILLE, Ky. - The University of Louisville Hite Art Institute presents "Unseen: Visualizing Ecological Systems," an exhibition curated by critical and curatorial studies master's candidate Madison Sevilla Jan. 12-Feb. 24 in Schneider Hall Galleries. "Unseen" features sculptures and drawings by Stephen Cartwright and Shohei Katayama that explore the intersections between art and ecology.

Cartwright's data visualization sculptures function as self-portraits created through detailed documentation of his life and routines. The sculptures contrast graphed data about his geographical location (such as wind patterns, temperature and precipitation) against his activity and mental health. Cartwright has compiled over 150,000 data sets over the past seventeen years and analyzes various trends to examine the scope of his existence. The artist then renders the data into a three-dimensional illustration.

Katayama's work is ecologically aware and he utilizes his drawings and sculptures as a catalyst for environmental conversations. Using materials like magnets, iron flakes and oil-based sharpies, his work showcases unseen relationships in ecology.

“'Unseen: Visualizing Ecological Systems' provides viewers with the groundwork to contemplate the impact on and interactions between the various systems that surround us," Sevilla said. "Cartwright and Katayama offer visualizations of the infinite and continuous ecologies that constitute our routines." 


\section{Figure 37:}

$3 / 30 / 2017$

Hite Art Institute offers exhibition that examines art and ecology I UofL News

Cartwright is an associate professor and associate director for the School of Art and Design at the University of Illinois in Urbana-Champaign, IL. He has exhibited work in various exhibitions around the country and works with a range of materials including glass and acrylic resins.

Katayama is a Japanese American artist based in Louisville. He has exhibited works in multiple exhibitions along the East Coast. In 2010, Katayama earned a BA from Bellarmine University and is currently working toward a Master of Fine Arts at Carnegie Mellon in Pittsburgh, PA.

The opening reception is 6-8 p.m. Jan. 12. Click here for directions to the Cressman Center Gallery, 100 E. Main St., and here for gallery hours. For more information, contact Reitz at cjreit02@louisville.edu.

\#\#\#

Niki King

Niki King Jones is positive she has the best job at the University of Louisville, serving the communication needs of the departments of fine arts and theatre, the School of Music, University Libraries and Alumni - all the fun, creative stuff. Before coming to UofL in 2015, Niki held communication positions in both private and nonprofit sectors in Louisville, Ky., including at Heaven Hill Distilleries and the Jewish Community of Louisville. For 10 years prior, she was a reporter at various newspapers across the country, most recently The Courier-Journal. Niki graduated from the University of Memphis with a BA in journalism and has a masters degree in community and leadership development from the University of Kentucky.

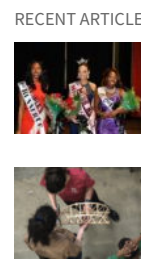

Miss Black UofL 2017 crowned

CAMPUS \& COMMUNITY MARCH 29, 2017

Speed School's E-Expo: Kids learn that engineering is fun

EDUCATION \& LEADERSHIP MARCH 28, 2017

13: UofL recognized for voter registration efforts

FRIENDIY campus \& COMMUNITY MARCH 27, 2017

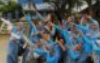

Job offer gives Fulbright scholar another year in Indonesia

EDUCATION \& LEADERSHIP MARCH 27, 2017

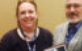

UofL professor receives career achievement award from Society of Toxicology

EDUCATION \& LEADERSHIP MARCH 27, 2017 


\section{CURRICULUM VITA}

NAME: $\quad$ Madison DeAnna Sevilla

ADDRESS: 5013 Fay Ave.,

Louisville, KY, 40214

DOB: $\quad$ Redwood City, CA. - July 17, 1993

\section{EDUCATION}

\& TRAINING: $\quad$ B.S. Art Management Appalachian State University

2013-2015

AWARDS: $\quad$ Cressman Scholarship

Hite Art Institute, Department of Fine Arts

University of Louisville

2015-2017

PROFESSIONAL SOCIETIES: American Alliance of Museums Student Member societies

Joined 2014

PUBLICATIONS: “On Marking Time.” The Hite Aegis Review. (www.hiteaegis.org), July 2016.

"The Sacrifice of Femininity." The Hite Aegis Review (www.hiteaegis.org), June 2016.

"Women as Decoration." Summer Breaks: Labor, Leisure, Lust. Hite Art Institute, 2016.

"Relationship." Point \& Counterpoint: NC Arts Council Fellows Exhibition. SECCA, 2015. 
PROFESSIONAL EXPERIENCE: Archives Assistant Buffalo Trace Distillery

Sazerac Company

01/17-Present

Archives Paid Intern

Buffalo Trace Distillery

Sazerac Company

$11 / 2015-01 / 2017$

Curatorial Assistant Internship

Southeastern Center for Contemporary Art (SECCA)

05/2015-08/2015

Research Assistantship to Professor/Gallery Director

Appalachian State University

01/2015-05/2015 